\title{
Estimates of Air Pollution Mitigation WITH GREEN ROOFS USING THE UFORE MODEL
}

\author{
by
}

\section{Beth Anne Currie}

B.Sc.N. Queens University, 1986

Post Graduate Diploma Science Communication, 1994

\author{
A thesis \\ presented to Ryerson University \\ in partial fulfillment of the \\ requirement for the degree of \\ Master of Applied Science \\ in the program of \\ Environmental Applied Science and Management \\ Toronto, Ontario, Canada, 2005
}

PROPERTY OF

Ryerson University Library 
UMI Number: EC53587

\section{INFORMATION TO USERS}

The quality of this reproduction is dependent upon the quality of the copy submitted. Broken or indistinct print, colored or poor quality illustrations and photographs, print bleed-through, substandard margins, and improper alignment can adversely affect reproduction.

In the unlikely event that the author did not send a complete manuscript and there are missing pages, these will be noted. Also, if unauthorized copyright material had to be removed, a note will indicate the deletion.

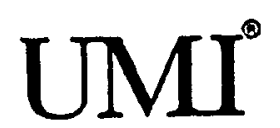

UMI Microform EC53587

Copyright 2009 by ProQuest LLC

All rights reserved. This microform edition is protected against unauthorized copying under Title 17, United States Code.

ProQuest LLC

789 East Eisenhower Parkway

P.O. Box 1346

Ann Arbor, MI 48106-1346 


\section{AUTHOR's DECLARATION}

I hereby declare that I am the sole author of this thesis.

1 authorize Ryerson University to lend this thesis to other institutions or individuals for the purpose of scholarly research.

I further authorize Ryerson University to reproduce this thesis by photocopying or by other means, in total or in part, at the request of other institutions or individuals for the purpose of scholarly research. 


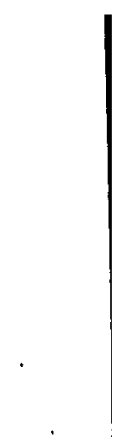




\title{
ESTIMATES OF AIR POLLUTION MITIGATION WITH GREEN ROOFS USING THE UFORE MODEL
}

A thesis presented to Ryerson University in partial fulfillment of the requirement for the degree of Master of Applied Science in the program of Environmental Applied Science and Management

Toronto, Ontario, Canada, 2005.

\begin{abstract}
The purpose of this study was to investigate the effect of green roofs on air pollution in urban Toronto. The researchers looked for synergistic effects in air pollution mitigation by manipulating quantities and species of trees and shrubs at gr ide level and grass on roofs within the study area. The effect of these veyetation manipulations were simulated using the Urban Forest Effects (UFORE) computer model developed by the USDA Forest Service Northeastern Regional Station, Syracuse, New York. Originally UFORE was developed to help forestry managers and researchers quantify urban forest structure and risks based on standard field, meteorological and pollution data. While UFORE contains four different assessment modules $A-D$, Module $D$ quantifies the effect of vegetation on air contaminants such as $\mathrm{NO}_{2}, \mathrm{SO}_{2}, \mathrm{CO}, \mathrm{PM}_{10}$ and ozone. UFORE also provides data about hourly air contaminant removal rates and it predicts an economic externality value in USD for total air contarninant removal. Six vegetation scenarios were developed within the Toronto study area to compare how different amounts of vegetation affect air contaminant levels. Results of the study indicate that grass on roofs (green roofs) could play a significant role in air pollution mitigation in an urban neighbourhood. By extension, a $10-20 \%$ increase in the surface area dedicated to green roofs on downtown Toronto buildings would improve air quality and quality of life for citizens in Toronto.
\end{abstract}




\section{ACKNOWLEDGEMENTS}

The author would like to first thank Dr. Ron Pushchak, of Ryerson University, for several offerings, not the least of which was to facilitate my entrance into the Master's of Environmental Applied Science and Management Program in January 2003. Since then Dr. Pushchak has provided a remarkable flow of mature and intellectual conversation that has helped me grow and manoeuvre the swift waters within the program. I am thankful for his patience, wisdom and encouragement.

Appreciation is extended to Dr. Brad Bass of Environment Canada's Adaptation and Impact Research Group, University of Toronto, whose passion for exploring the role of green infrastructure and technologies within adaptive urban ecosystems has strengthened Toronto-based research findirgs, established reliable funding sources and inculcated academic rigour into local green roof projects. Thank you for bringing me into this circle of study and for making space for this research. Thank you to Sadia Butt for providing technical support and colleagueship along the way!

The author would like to acknowledge, Margie Zeidler, of 401 Richmond Ltd, whose vision and determinations over the past 10 years have preserved historic buildings and the natural environment in Toronto's urban core. Margie has channelled her vision carefully as three downtown historic buildings now boast a complement of green installations (green roofs and a biowall) with more predicted in the future. As my employer and friend, Margie has shaped my passion for urban renewal and the role that natural elements play in the process. Margie has made the phrase "going green" more than a possibility at urbanspace PROPERTY GROUP.

Unlimited thanks and appreciation to the primary person in my life, without whom I would not have made the quantum 'leap of faith' to start and finish this academic journey. Kathy Underwood, for all of this and more - I am forever grateful.

To my parents - Ken and Eleanor Currie - a special thanks for modelling a value system where commitment and dedication to activities which foster the "greater good" bring us closer to connections in the environment and in the global community. For these parents - I have been richly blessed. 


\section{TABLE OF CONTENTS}

Author's Declaration

Abstract

A.cknowledgements

List of Tables

List of Figures

List of Appendices

Chapter 1: Introduction and Study Information

Introduction

Study Background

Study Hypothesis

Study Assumptions

Chapter 2: Background

What is a Green Roof?

Green Roof Terminology

A profile of Extensive and Intensive Green Roofs

Chapter 3: Literature Review

Green Roof Research in North America

Stormwater Management

United States Stormwater Regulations and Green Roof Development

Canadian Stormwater Research

Ottawa

Toronto

Vancouver

Urban Heat Island Effect

Urban Heat Island and New York City

Building Roof Membrane Performance

Building Energy and Heat F.lux

Peak Energy Values

Habitat Restoration and Conservation

Air Pollution and Green Roofs

The Problem with Air Pollution

The Economics of Air Pollution

Air Pollution and the Natural World

Vegetation and Air Pollution

Conclusion 

Chapter 4: Method

Study Method

UFORE Computer Model

UFORE-D

UFORE-D and Plants

Pollution Deposition

Scenarios 1

Scenarios 2

Scenarios 3

Scenarios 4

Scenarios 5

Scenarios 6

Chapter 5: Results

Chapter 6: Discussion

Summary

Chapter 7: Conclusion

Refarences

\section{Appendices}

Appendix 1: Northeastern Research Station - UFORE Model- Project Summary

Appendix 2: The Urban Forest Effects (UFORE) Model: Field Data Collection Manual

Appendix 3: Raw Data 



\section{LIST OF TABLES}

Chapter 2

Table 1:

Chapter 3

Table 2:

Table; 3:

Table 4:
A Profile of Extensive and Intensive Green Roofs

Cumulative rainfall and runoff rates Ottawa site

Thermal comparisons between reference and green roof, Ottawa site

30

Comparison between the total annual energy consumed for heating and

34

cooling 


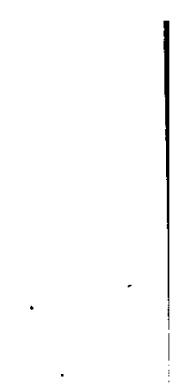




\section{LIST OF FIGURES}

Figure 1

Green Roof Layers

10

5

Figure 2

Effect of Green Roof Soil Depth on Performance During Wet Weather

Figure 3 .

Figure 4

Figure 5

Figure 6

Figure 7

Figure 8

Figure 9

\section{Chapter 4}

Figure 10

Figure 11

Figure 12

Chapter 5

Figure 13

Figure 14 Effect of Green Roof Soil Depth on Performance During Drier Weather with High Intensity Cloudbursts

Effect of Total Rainfall on the Volume Reduction Benefits of Green Roofs

Basic Roof Energy Balance

29

Temperature profile within the roofing systems on a summer day (July 16,2001 ) indicating that the Green Roof reduces the temperature fluctuations within the roofing system

Temperature measurements showed that the Green Roof significantly reduced the daily temperature fluctuations experienced by the roofing membrane.

Heat flow through the roofing systems on a summer day (July 16 , 2001) indicated that the Green Roof reduced the heat flow through the roofing system significantly.

Summer cooling reductions achieved within multi-story building

Toronto Wards

44

Sample plot in Midtown

45

UFORE-D and Plants

Total CO removal $(\mathrm{Mg})$ by trees, shrubs and grass in Midtown per 60 Annum Annum

Figure 15 Total $\mathrm{O}_{3}$ removai $(\mathrm{Mg})$ by trees, shrubs and grass in Midtown per

62

Figure 16 Total $\mathrm{PM}_{10}$ removal $(\mathrm{Mg})$ by trees, shrubs and grass in Midtown per

63

Figure 17 Total $\mathrm{SO}_{2}$ removal (Mg) by trees, shrubs and grass in Midtown per

Figure 18 Total pollution removal value (US\$) by trees, shrubs and grass in

Figure 19 Proportional Removal Values for the Effect of Grass Roofs on Air 



\section{LIST OF APPENDICES}

Appendix 1 UFORE Model Project Summary

Appendix 2 UFORE Model Field Collection Manual

Appendix 3 Raw Data for UFORE Model 


\section{CHAPTER 1: INTRODUCTION AND STUDY INFORMATION}

\section{Introduction}

Use of vegetation on walls and roofs of buildings, particularly roofs, is a common practice in the architecture of older buildings in countries like Iceland, Scandinavia, Switzerland, Germany and Tanzania. Historically, people in these countries utilized vegetation in the form of vines on walls, shade trees near buildings and grass on roofs, hitherto known as green roofs, to provide: wind protection; shade from hot summer temperatures; insulation for winter warmth and summer cooling; as well as to enhance the aesthetic value of the building. Canadian prairie pioneers constructed buildings with sod bricks for use in wall and roof construction where the soil and plants acted as a protective structure and insulation material in both summer and winter months. In the 1970s an interest in studying the environmental benefits provided by vegetative elements applied to buildings prompted researchers to examine the effects of green roofs on building performance. Throughout Europe, particularly Germany, the last thirty years have produced a compliment of academic green roof research, predictable research funding and a proliferation of green roof installations. These accumulated study results have helped to formalize European municipal policy guidelines, regulations and financial incentives that today, support a thriving European green roof economy. After nearly thirty years of this mostly German science, knowledge and expertise in green roof construction technologies in Germany is unsurpassed in the western world $(29,86,87,90)$.

As green roofs and research have proliferated throughout Germany and Europe, so too have the improvements in green roof technology in response to increased market demand. Europe and, more recently, North America boast a complement of green roof expertise including green roof consultants, plant specialists, adapted green roof irrigation systems, electronic roof leak detection systems, green roof drainage technologies, root barrier technologies, synthetic planting media technologies and horticultural practices $(80,85,86,87,90)$. It is estimated that while over 10 million square meters of green roof have been 
installed in Germany over the past two decades, this represents only $14 \%$ of the total flat roof surface available (39). While North American green roof installations lag behind our European counterparts, so to does the availability of peer-reviewed publications that support and quantify the regional differences and similarities among the purported myriad of environmental benefits associated with green roofs. Studies across North America tend to be university-based technical and construction-based research studies that concentrate on: stormwater runoff quantity and quality; thermal energy and roof membranes; urban heat island effects; plant and substrate compositions; policy reports; and social/recreational benefits associated with green roofs.

\section{Study Background}

There is currently very little scholarly North American research available to quantify the environmental benefits associated with green roofs. Literature supporting these benefits tends to be scattered, brief and mostly available in proceedings from two recent international green roof conferences - one in Chicago, Illinois, (2003) and one in Portland, Oregon, (2004). To date, this literature has focused mostly on case studies of demonstration projevis across several North American cities. Other research has examined the role of different substrate depths, substrate types, degree of plant coverage and the effect of slope on stormwater runoff quantity and quality. Ottawa-based research at the National Research Council has explored how green roofs contribute insulation value to buildings, especially in summer months. Of note is the dearth of evidence in the existing literature to support the air pollution benefits associated with adding vegetation to roof surfaces in urban areas $(6,9,17,29,87)$. Studies that quantify air pollution benefits might play an important role in guiding the formation of urban green roof policy especially if green roofs can be shown to improve air quality and by extension the quality of life in urban areas. 


\section{Study Hypothesis}

The thesis hypothesis was that the UFORE (Urban Forest Effects) Computer Model could quantify the mitigation effect of green roofs (vegetation layer, that is grass, installed on conventional roofs) on levels of air pollutants or contaminants in a study area within City of Toronto. The UFORE Model was chosen because of its accepted use within the scientific community of urban and regional foresters throughout North America. The UFORE computer model uses measured field data inputs as well as local hourly meteorological data and air pollutant concentration measurements (collected from Environment Canada, 1998) to quantify neighbourhood-specific vegetation effects on urban air pollutant concentrations (76).

As a result, the study objectives were to estimate:

- Air pollution benefits derived from different subsets of trees, shrubs and grass on roofs

- If a quantified surface area of green roof coverage could be recommended to inform urban policy

- If the UFORE Computer Model provides a systematic and consistent method for determining the air pollution benefits derived from green roofs in urban neighbourhoods

\section{Study Assumptions}

The principal research questions imbedded in the study were as follows:

1. Can the UFORE Computer Model generate air pollution outputs from a smaller neighbourhood study area of green roofs within the City of Toronto?

2. Will these UFORE Model air pollution outputs facilitate green roof design (size or surface area) parameters for the City of Toronto?

To answer these questions there were a number of assumptions that needed to be held: 
1. That UFORE Module D could respond to the grass-on-roof (green roof) vegetation inputs that did not fit the typical input data provided by fieldderived tree and shrub species parameters within the study area.

2. That UFORE Module $D$ could respond to the addition of green roof vegetation inputs on surface areas of neighbourhood roofs and be interpreted in the same manner as adding tree and shrub inputs at grade level.

3. That UFORE MODULE $D$ could distinguish differences between vegetation scenarios and their effects on individual air contaminant levels.

As such, the research focused on the resultant individual air contaminants derived from UFORE Module $D$ that showed incremental changes associated with the manipulation of vegetation types within the study neighbourhood. 


\section{CHABTEA2: BACROROUND}

What is a creer Roor?

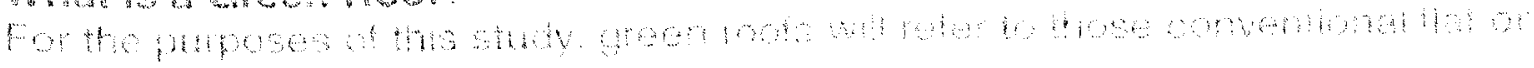

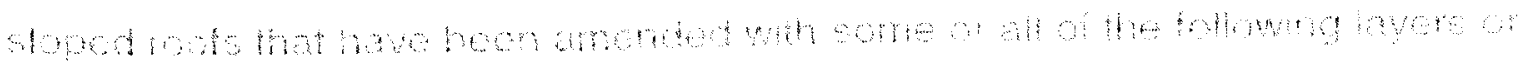

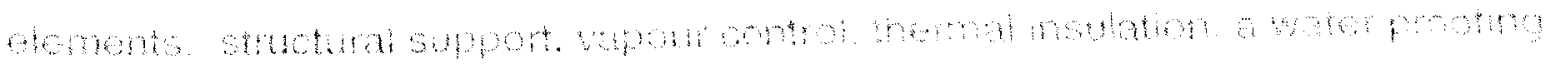

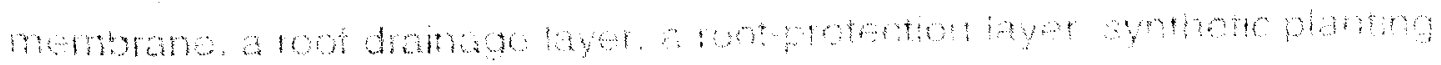

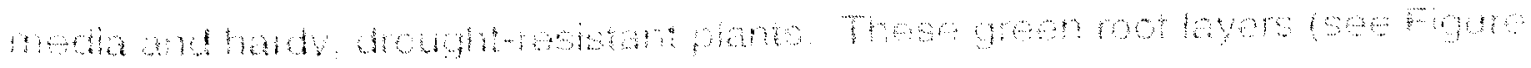

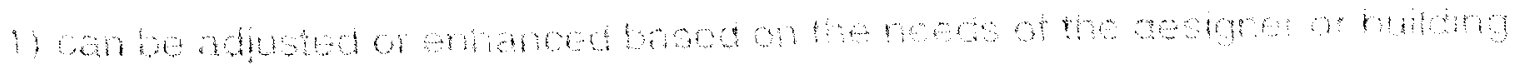

owmer

Ficue : Greer Foot Lavers

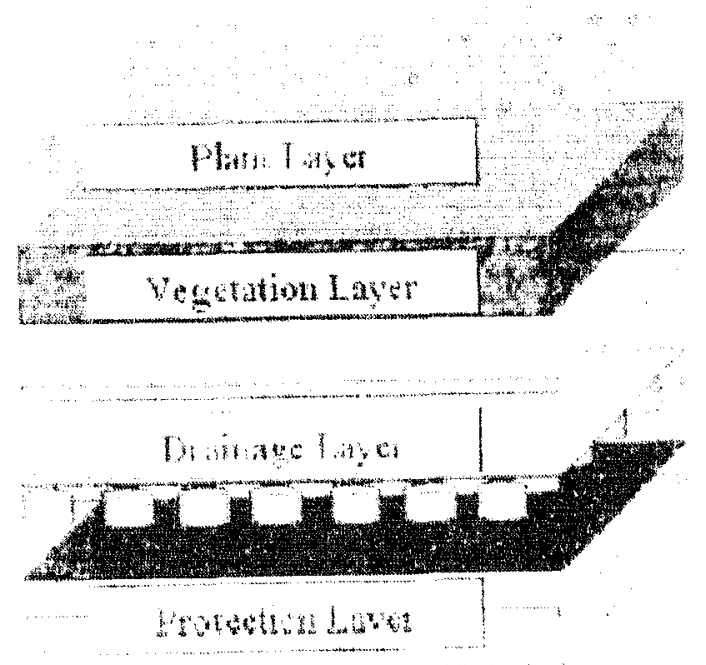

\section{Green Root Terminology}

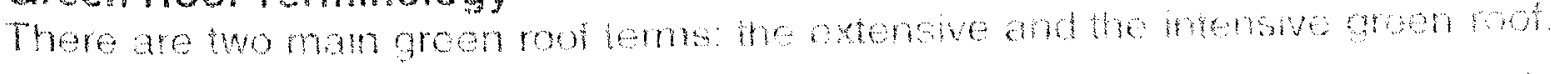

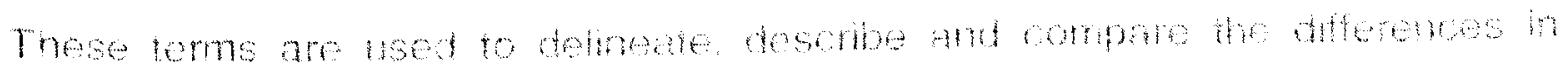

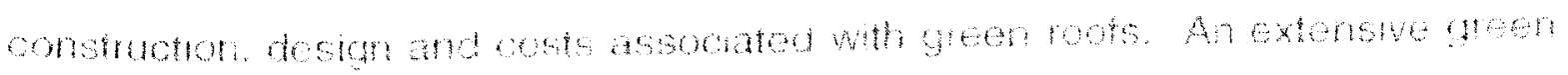

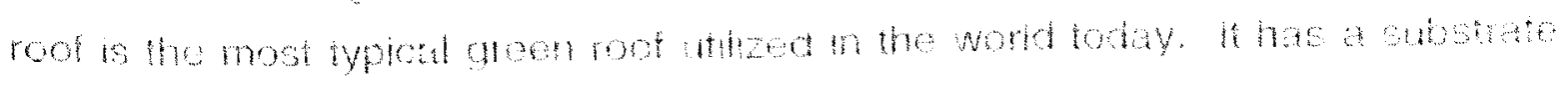

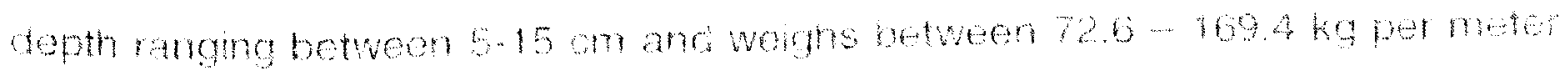


squared (87). A shallow soil or a soil-less synthetic planting medium is required on most roofs to decrease loading weights and meet acceptable building code und structural demands. These low-weight synthetic planting media combined with challenging microclimate conditions associated with prevalent wind, drought and high temperatures present on an elevated surface, necessitate plant species choices that are hardy, low in height, and drought-resistant. According to many authors, minimal technical expertise or practical experience is required to install and maintain an extensive green roof; however, the success of any roof is measurf, d by the survivability of the plants therein. Ongoing plant and substrate research is contributing to green roof success across North America $(11,31,38$, $39,43,46,81,85,93,101,111,120)$.

Their heavier weights, deeper planting media, irrigation systems, landscaping planning and design and complex roof engineering characterize intensive green roofs. In contrast to extensive green roofs, intensive roofs are eligible for a much broader plant species selection (including trees and shrubs), as well as other design features such as ponds and decorative landscaping formations. Intensive green roofs require costly roof structural upgrades and necessitate higher overall maintenance costs as they are often installed by an experienced landscaper and require heavy equipment including overhead cranes to convey materials up to the roof.

Table 1 delineates the major characteristics that differentiate extensive green roofs from intensive green roofs. Of particular note are the differences in weight, cost, structural preparation, water retention, predicted thermal benefit and public versus private benefits. 
Tabie 1: A Protile of Extensive and mrensive Green Roors

\begin{tabular}{|c|c|c|}
\hline Ront Tyos & Extensive creen hoor & Intensive Green Root \\
\hline $\cos$ & 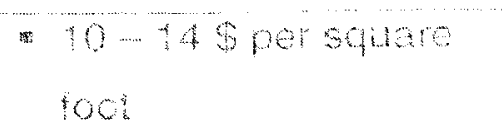 & 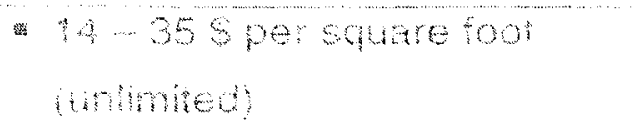 \\
\hline $\begin{array}{l}\text { Growing media and } \\
\text { plant selection }\end{array}$ & 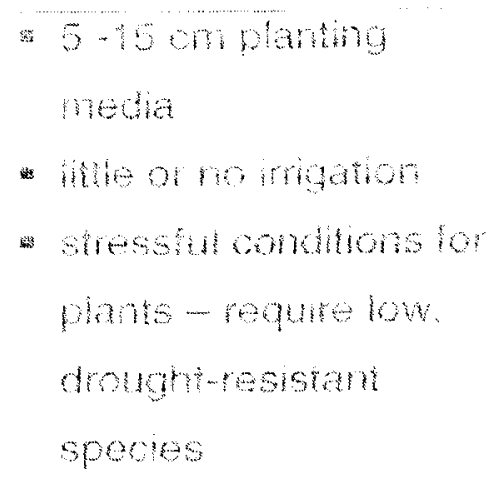 & 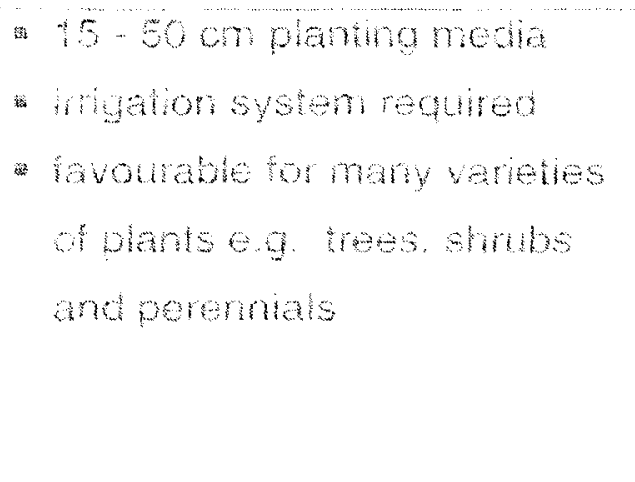 \\
\hline Structural preparation & 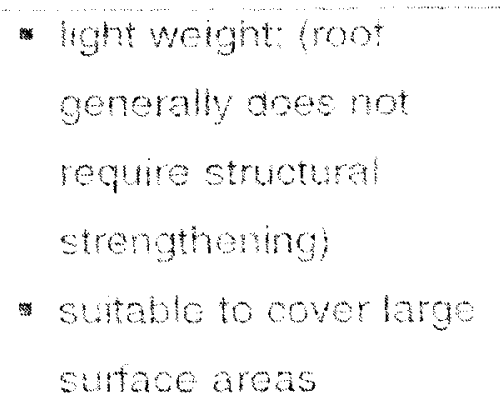 & 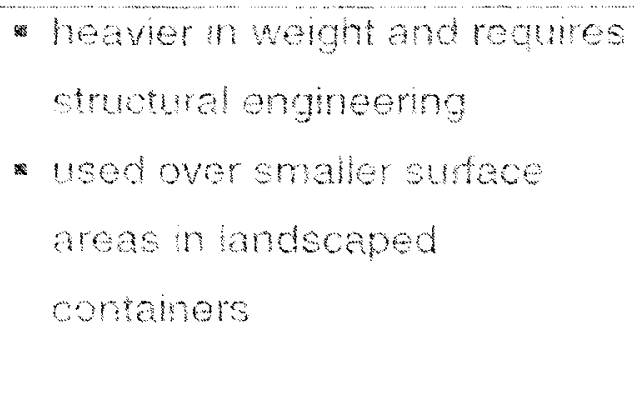 \\
\hline $\begin{array}{l}\text { Insulation value } \\
\text { (energy savings) }\end{array}$ & $\begin{array}{l}\text { So msulation added } \\
\text { valuo for buldng } \\
\text { savmgs (summer } \\
\text { coolnu) }\end{array}$ & $\begin{array}{l}\text { smiar meubton value } \\
\text { commer coolng if covers } \\
\text { samo sumace area }\end{array}$ \\
\hline Stormwater & $\begin{array}{l}\text { - } 5 \text { - } 10 \text { o peak flow } \\
\text { reduced in } 5.10 \mathrm{~cm} \\
\text { phinting dept }\end{array}$ & $\begin{array}{l}\text { not well swidied or compared } \\
\text { on intenswe roots }\end{array}$ \\
\hline Arr pollution & $\begin{array}{l}\text { *migates ar } \\
\text { contamiants }\end{array}$ & 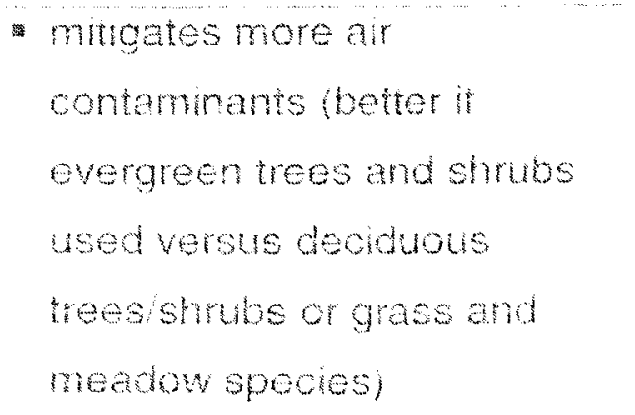 \\
\hline
\end{tabular}




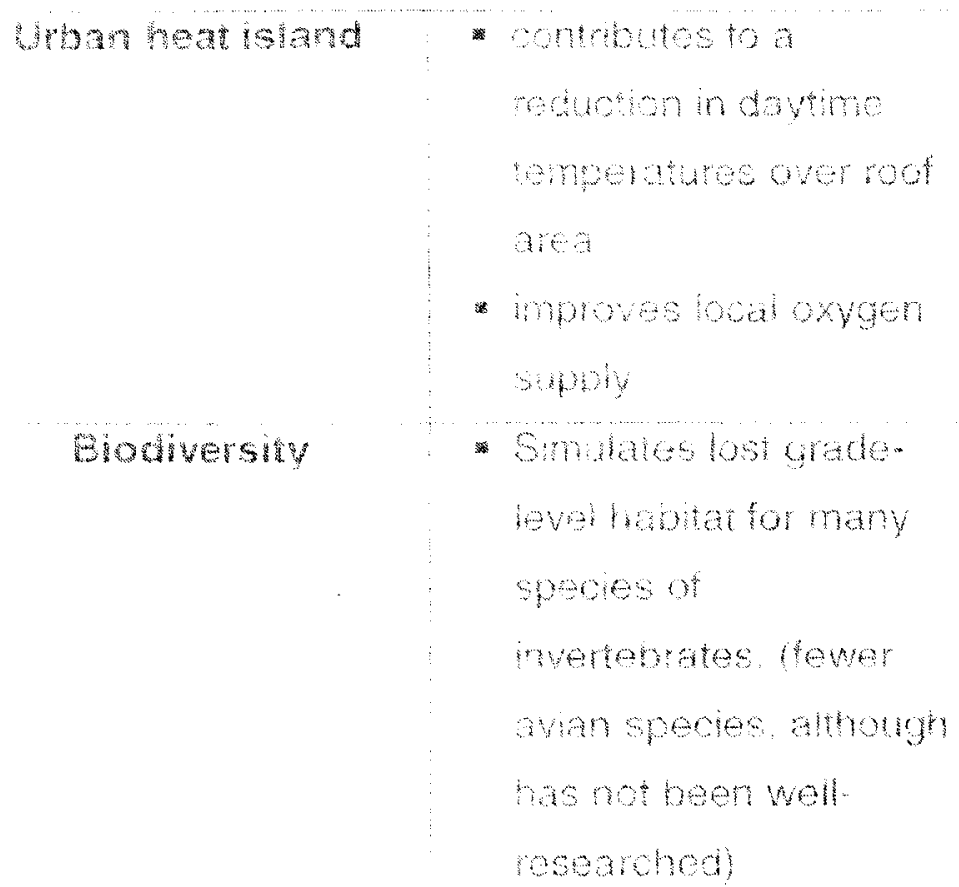

Publit Access
* contribuse 10 greator roduction in daytme lomporature as troes and strubs provide more active cvapotanspiration

* moroves oxygenation

- Allows for greater diversty of plant species and provides habitat for birds (Black Redstarts, starlings: chickadees and sparrows to name but a fow

* beetles spiders and other invertebrates

* Simulates lost habitat for wildite birds and hertage seeds from grade level

" suitable for public access. more aesthetically-positive as roof can be used for meeting recreational need (Singapore. 2003 ) and for food production

* deeper planting media supports, more biodiversity. more overall envirommental benotits and more socialpsychological benefits by accossing recteational roof space 


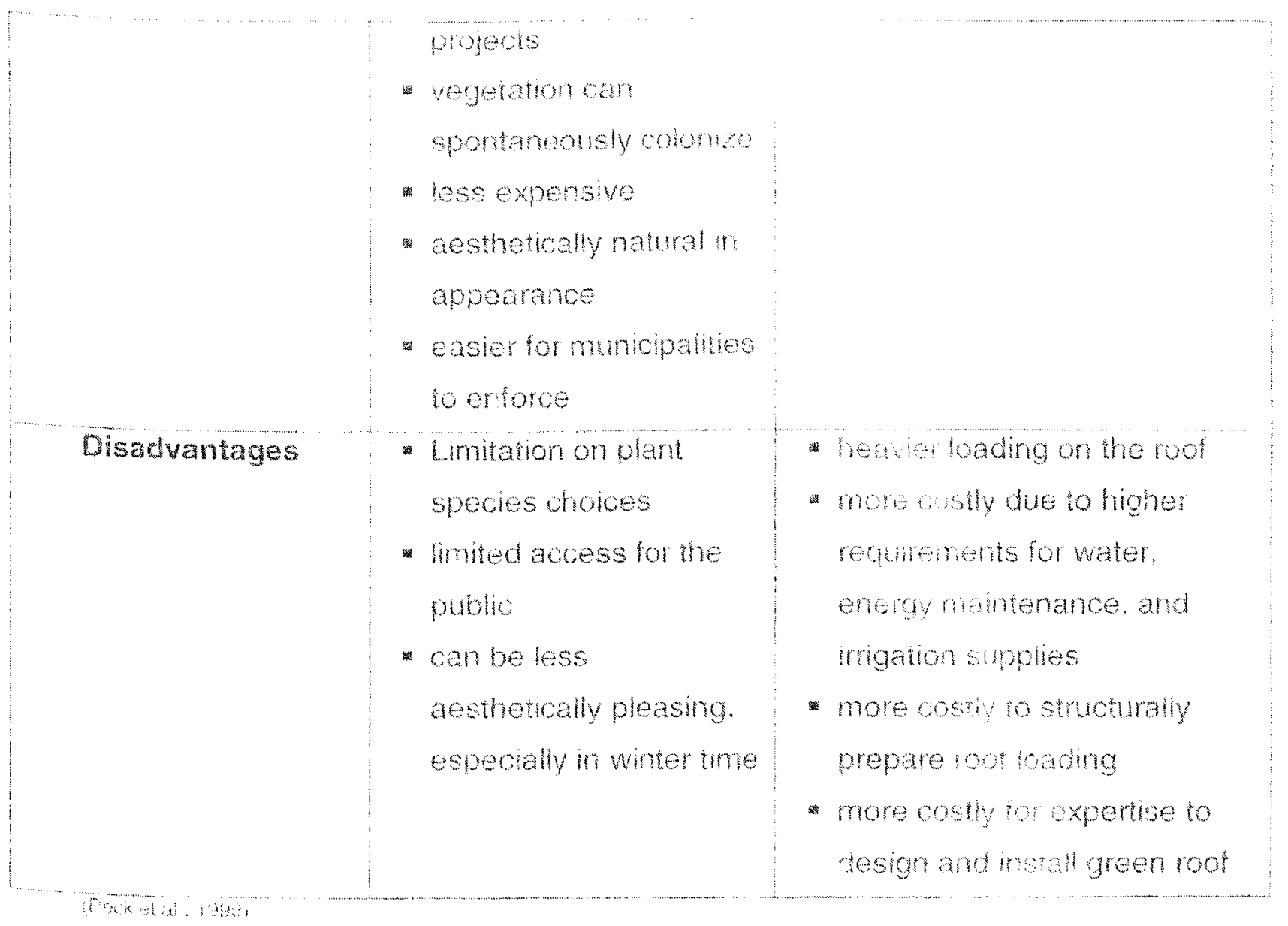




\section{Chapter 3: Literature Review}

\section{Green Roof Research in North America}

As we approach the first decade of scientific exploration, green roof research is slowly becoming more established in North America. Green roof research has been guided by interdisciplinary scientists wishing to establish, compare and analyze the performance of green roofs on environmental parameters in North American climate zones, using North American plants, across varying regions and contexts. For example, the findings of urban stormwater runoff quantity and quality studies can differ between Vancouver, British Columbia and Toronto, Ontario, based on plant species, substrate choices, slope, rainfall patterns and green roof construction materials. Similarly, urban heat island, air pollution mitigation, roof membrane longevity, heat flux, insulation capacity, plant types, soil depths, biodiversity and species conservation can differ by province, region and climatic zone acress North America. As yet, there is no common baseline for comparisons within the Nortn American context.

Green roof research is notably dispersed across a wide range of researchers including: soil and horticultural scientists, civil and construction engineers, architectural scientists, landscape designers, climate change meteorologists, air pollution experts, ecologists, roofing specialists, urban planners and policy developers. North American research, while relatively new compared to Europe, is informing green roof installations, policy development and implementation as well as achieving measurable penetration in the marketplace. Market expansion is especially observable in cities like Chicago, Illinois, Portland Oregon, Washington, D.C., New York City, Atlanta, Georgia, Vancouver, British Columbia and Toronto $(10,16,37,42,43,46,51,70)$. Comparatively, European countries have lead the world in green roof research as a response to urban sprawl, polluted stormwater runoff, lost green space, air pollution, urban heat island effects and species at risk. Consequently, Europe has more mature and tested green roof municipal regulations and financial incentives to promote the installation of green roofs. 


\section{Barriers to Canadian Market Development}

One of the barriers to widespread adoption of green roof technology in Canada is the lack of technical data on green roof performance and longevity within the Canadian context. In the absence of technical data, it is difficult for developers, lenders, roofing contractors and building owners to acquire education and awareness, and those who do receive it, are hesitant to adopt the technology. Moreover, the additional 'up front' cost (see Table 1, chapter 1) associated with installing a green roof compared to a conventional roof is a real financial barrier that has yet to be removed. Nonetheless, ongoing contributions by technical and scientific green roof research facilities, with carefully instrumented green roofs for data collection and comparison, coupled with an academic commitment for knowledge transfer, are expected to build baseline data across North America. Canada has three established research facilities, while the remainder are located in the United States $(8,10,43,58)$.

\section{Green Roof Policy; Europe and North America}

In European countries such as Switzerland, Austria and Germany, developers are less concerned by the perceived added costs associated with the installation of green roofs $(13,14)$. It seems that Europeans are guided by a longer-term vision for the performance and longevity of built form compared to that of North Americans. In Europe, buildings are designed to last approximately 50-100 years, compared to the 20-25 year projections currently used in North America (13). In Switzerland, the building code necessitates that new developments possess a cement roof. Cement is a building material that can be reclaimed and recycled from other buildings that require demolition. Cement not only strengthens the building and adds to its longevity, but also makes the roof ideal for the additional loading requirements of an intensive green roof. In Basel, Switzerland, the building code necessitates the incorporation of a green roof that protects and sustains the biodiversity of native invertebrate species. The Basel, Switzerland building regulation specifies that a developer must incorporate a green roof, and consult with Dr. Stephan Brenneisan, a scholar in the design and study of biodiversity on Swiss green roofs, in all new building projects in the 
city $(13,14)$. Other environmental pressures, such as a lack of available urban space for development, air/water pollution and an over-reliance on drinking water sources that have traversed several countries and their waste water treatment plants before reaching the down stream water purification facility, have motivated European governments to adopt mitigation strategies such as green roof technology and sustainable building design.

Some European governments have amended their building codes and developed regulations while others have used financial incentives to encourage builders and developers to consider green roof technology. For example, the Split Waste Water Act (SWWA) in Germany allows municipalities to change the tax structure levied to building owners based on the amount of stormwater runoff generated by a particular property (103). In these countries, a stormwater fee is calculated by the percentage of a building's total impervious surface area comprised by parking lots and rooftops, compared to that of its total footprint area. Hence, the addition of a green roof decreases a building's impervious surface area and curbs the costs associated with the SWWA $(88,103)$. This policy direction places a share of the responsibility for abating water pollution in the form of stormwater runoff directly on the building owner.

Throughout North America, a system called Leadership in Energy and Environmental Design (LEEDTM) is helping to raise the profile of sustainable building practices more common in Europe (49). LEEDTM is a USA-based, nongovernmental rating system for developers that is administered by the National Green Building Council. LEEDTM criteria have been established to ensure that building projects meet a variety of environmental design goals, such as water and energy conservation, in-door air quality, reduced urban heat island impacts, reduced impact on wildlife and many other criteria. Throughout North America, municipalities like the City of Portland, Oregon and the City of Chicago, Illinois have begun to promote LEED'M certification on their public buildings. Green roofs are a recognized mechanism to attain credits on the LEED ${ }^{\text {TM }}$ rating scale 
(28). Some authors suggest that LEED ${ }^{\mathrm{TM}}$ certified buildings have a stronger marketing edge over others in a similar market (88). Other incentives that fostered green roof policy development in the City of Chicago include the Energy Conservation Code. This ordinance was passed in 2001 and made all new and retrofit roofs meet a minimum standard for solar reflectance (48). The ordinance was shaped in response to a severe heat wave (1996) in Chicago that contributed to a significant number of deaths, particularly in senior citizens. Green roofs became an accepted form of low reflectivity and helped to mitigate urban heat island effect and thereby improve Chicago's air quality (48). In addition, Chicago grants a density bonus option to developers in the form of a floor area premium. To qualify for more intense development or more floors, a minimum of $50 \%$ of the roof surface area or a minimum of 2000 square feet (whichever is greater) must be covered by vegetation (38).

According to some authors, the City of Portland, Oregon, leads North America in supportive green roof policy (113). In 2001, Portland's Bureau of Environmental Services and the Office of Sustainability combined forces and created financial incentives to encourage green roof research on local demonstration projects. Currently, the City of Portland offers technical assistance, access to accumulated research data and access to grant monies to further the development and installation of green roof demonstration projects. Similarly, the City of Portland's City Public Works Code 17.38 now requires that stormwater runoff be managed at source. Green roofs, or eco-roofs as they are called in Portland, meet water quality and peak flow control requirements of this new code (51). Finally, Portland's Floor Area Ratio (FAR) Bonus allows green roofs or eco-roofs to support an application to develop more space. For example, if an eco-roof is projected to cover up to $30 \%$ of the roof surface area, one square foot of bonus space is allowed for each square foot of eco-roof. Moreover, where an eco-roof is expected to cover greater than $60 \%$ of the roof surface, each square foot of eco-roof generates three square feet of density bonus (51). 
Policy development in Canada lags behind that of Europe and the United States. The cities of Vancouver, Toronto and Ottawa have green roof research facilities integrated at the academic level with demonstration projects that are contributing to a greater understanding of the environmental benefits offered by green roofs. In 2003 the Greater Vancouver Regional District (GVRD) completed a GIS-based inventory of green roofs and was purported to be the first database of its kind in North America (22). The GVRD has established a working group where municipal, provincial and federal levels of government will coordinate green roof research and provide a forum for exchanging technical data on green roof performance, explore policy options and promote green roofs in the Vancouver Region. In October 2004, the British Columbia Institute of Technology (BCIT) opened its green roof research facility to 1,200 square feet of research roof area. Green roof data from BCIT will be shared with researchers in Ontario, in particular, the Toronto Region Conservation Authority-based consorlium and the Ottawa-based National Research Council, Institute for Research in Construction, Field Research Facility (53). Toronto's green roof demonstration projects, a first for Canada, are located at Eastview Community Centre and on the podium roof at Toronto's City Hall. Environmental benefits are being quantified via extensive instrumentation within the roof membranes and growing media on green roofs in Toronto and Ottawa.

Policy incentives that directly impact the development and installation of green roofs are currently lacking in Canada. According to some authors, the use of direct or indirect public incentives for green roofs is preferable over more traditional regulatory approaches, as evidenced in Chicago. Regulatory approaches shift the burden of additional capital costs associated with green roofs directly on to the building owner or developer - while direct or indirect incentives may stimulate the market using traditional municipality-based funding mechanisms. A large number of criteria influence the choice of design and implementation of a particular policy instrument. Factors such as how quickly the instrument needs to be implemented, how expensive the instrument will be for 
tax payers and building owners, as well as the overall cost consideration for the municipality will influence the outcome, especially if enforcement, inspection or monitoring is part of the implementation strategy (34). The challenge for any Canadian jurisdiction will be to determine which green roof policy instruments (government grants, subsidies, low interest loans, or tax expenditure) will promote local industry.

In the next sections of the literature review, a summary of research reports that quantify the environmental benefits associated with green roofs will be profiled.

\section{Stormwater Management}

Impervious urban surfaces contribute to the diversion of stormwater or runoff rainwater away from land into engineered municipal systems. Impervious dark surfaces also contribute to the solar gain and subsequent urban heat island effect noted in urban areas throughout the world $(2,3,8,14,15,23,27,28,33$, 54,58 ). According to studies by the Toronto and Region Conservation Authority, approximately $25 \%$ of urban land development area in new subdivisions in Ontario replaces native or green natural habitat with impervious surfaces (58). Similarly, according to a study by the City of Portland, Bureau of Environmental Services, American cities are comprised of as much as $30-90 \%$ impervious surfaces. Impervious surfaces include rooftops and other asphalt surfaces (51).

Impervious surfaces create problems for municipalities, human and natural communities in urban areas for the following reasons:

- In a rain event, stormwater runoff becomes contaminated with pesticides, oil, grease, heavy metals, rubber, and garbage from roads, driveways, parking lots and roofs as it hits surfaces, accumulates and travels toward engineered urban storm drains. Polluted water journeys untreated and unchecked toward local rivers, wetlands, lakes and other bodies of water (20). 
- Combined sewage overflows (CSOs) and sanitary sewage overflows (SSOs) occur when stormwater systems (combined sewer and storm systems) reach maximum capacity and overflow during heavy rainfall or in a typical spring runoff. In Toronto, diluted raw sewage may be discharged into local streams and rivers that feed contaminated water to Lake Ontario with a resulting host of negative environmental and human health impacts $(20,58)$.

- A steady drop in local water tables (related to the lack of infiltration from urban impervious surfaces) has been affected by the engineered storm water redirection into viaducts, underground concrete conduits, and stormwater outflows, which terminate in major bodies of water $(104,106)$.

- Stormwater runoff increases shoreline water temperatures, particularly during summer months and impacts the habitat for aquatic plants, fish and animals and encourages algae blooms along stormwater outlets.

- Shoreline erosion results as the speed, turbidity and volume of engineered stormwater runoff follows a storm event $(20,58,110,106)$.

Research on the stormwater benefits attributed to green roofs is being conducted at several facilities across the United States and Canada. According to North American Wetland Engineering, Pennsylvania, one of the most tangible benefits of green roofs is their ability to retain stormwater runoff during the first hour of a storm event and thereby reduce the amount of runoff water reaching combined sewer networks $(17,60)$. The City of Toronto incurred over 22 CSOs during the summer of 2004 and incurred financial penalties not only from the Ministry of the Environment but from lost revenues that accompany beach closures related to Public Health advisories (20). Municipalities are particularly concerned about the first 1-2.5 cms of stormwater runoff, referred to as the first flush. According to some research, this initial runoff water carries the most concentrated pollutants from impervious surfaces (28). 
Green roofs are estimated to absorb, filter, retain and store an average of about $50-75 \%$ of the precipitation that falls on them, especially during the first hour of a rainfall event. The water retention capacity of a green roof varies according to the type of growing media used - that is, if the growing media include a lightweight, water-retaining aggregate in the matrix - its water-retaining ability will be higher than those that do not. Growing media comprise an area of current study at green roof research facilities, where competing companies are involved in comparative studies that examine water retention, volume, load, quality of stormwater runoff and plant nutrition capability between product groups. Many stormwater studies indicate that a layer of planting medium 6-8 cms deep in an extensive green roof can absorb about up to $2.5 \mathrm{cms}$ of water, or in some cases up to $50 \%$ of the water that falls in a rain event $(28,51,58,70,96)$.

\section{United States Stormwater Regulations and Green Roof Development}

The United States passed Phase II Final Rule of the National Pollutant Discharge Elimination System (NPDES) in 2001 and intensified the requirements for stormwater permits by emphasizing the importance of stormwater Best Management Practice $\approx$ r BMPs. BMPs such as bio-retention areas, wet and dry detention ponds, swales, constructed wetlands and sand filters are now commonly utilized throughout Canada and North America $(51,20)$. The Phase II Rule challenged developers and planners in dense urban areas like Raleigh, North Carolina to think about how green roofs could contribute to stormwater management and stimulated the need to support green roof research at the University of North Carolina (UNC). At UNC, researchers compared green roof retention and runoff rates, differing soil depths and sloped roofs to conventional urban roof performance. Findings from South Carolina support Canadian research by Liu and McMillan where green roofs significantly reduced first flush peak flow runoff rates and retained on average about $50 \%$ more rainwater than conventional roofs $(53,58)$. Research by Thompson demonstrated that green roofs can retain up to $60-100 \%$ of the stormwater they receive especially when soils are dry and unsaturated before a rainfall event (107). Many researchers 
concur that green roofs perform best at retaining rainwater when there has been adequate time for evaporation to occur between storm events $(107,70,58,110$, 104, 96).

Interestingly, researchers have reported that stormwater runoff quality may be hindered by green roofs. Two reports note that green roof runoff leachage levels tested for nitrogen and phosphorous were higher in green roof stormwater runoff data compared to conventional roof data $(51,70)$. This complements work by MacMillan who reported that runoff water quality parameters such as nitrogen, phosphorous, e-coli, heavy metals and copper were higher from the green roof runoff at York University, Toronto, compared to the reference roof. Findings like these have researchers and regulatory bodies responding to synthetic media supply companies for more stringent testing and research on leachate runoff quality over time before bringing products to market (58).

Rowe's (2003) investigations at the Centre for Green Roof Research compared green roof parameters against conventional roofs by varying types of growing media including PEPP (porous expanded poly propylene), using different planting media, varying depths, slopes and testing these differences against several varieties of Sedum. These data were compared to pre-existing German studies by Liesecke (41), who noted that differences in rainwater retention were commensurate with depths of plant media, such that more robust plant communities on green roofs contributed to a greater ability to retain stormwater. Rowe (2003) has demonstrated that in over 24 rain events, the Sedum green roof retained over twice the amount of rainwater as the conventional gravel ballast roof. The conventional roof had a $75 \%$ runoff rate, whereas green roofs resulted in $37 \%$ and $34 \%$ runoff rates, respectively. This translates to $63 \%$ and $66 \%$ retention rates.

Schade (2000) reported that the quantity of roof runoff obtained from a thin (2-3 $\mathrm{cm}$ ) layer of extensive green roof at slopes of $1,2,10,20$, and 30 degrees was commensurate with the slope of the roof. This finding was supported by Rowe 
(2003) such that a more sloped roof provides a greater quantity of roof runoff in a shorter period of time. Overall, leading stormwater researchers concurred that green roofs retained between $50-60 \%$ of their stormwater $(51,53,54,96,98,70)$ and that in all cases, the more rainfall, the greater the amount of runoff that was rendered from all roofs. However, in addition to reducing the total volume of runoff, vegetated roofs also reduced the peak runoff rate and delayed the total runoff volumes $(51,53,107)$.

\section{Canadian Stormwater Research}

\section{Ottawa}

Ottawa-based research completed by Liu and Baskeran provided a groundbreaking report on the effect of green roofs on stormwater runoff. As such, their research is well cited across construction and engineering-based stormwater literature and provides a benchmark for comparisons of green roof performance $(28,58,70,96)$. Results shown in Figure 1 are profiled for stormwater runoff from six inches of planting media (see performance for runoff ' $G$ ') compared to a conventional or reference roof (runoff $R$ ) at the National Research Council, Institute for Research in Construction, Field Research Facility green roof site in October, 2001. It was revealed that after a light rain event (34 $\mathrm{mm}$ ) over 15 hours in October 2001 the green roof provided a significant delay in the start time for rainwater runoff and reduced the rate and volume of runoff available. 


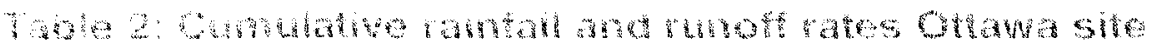

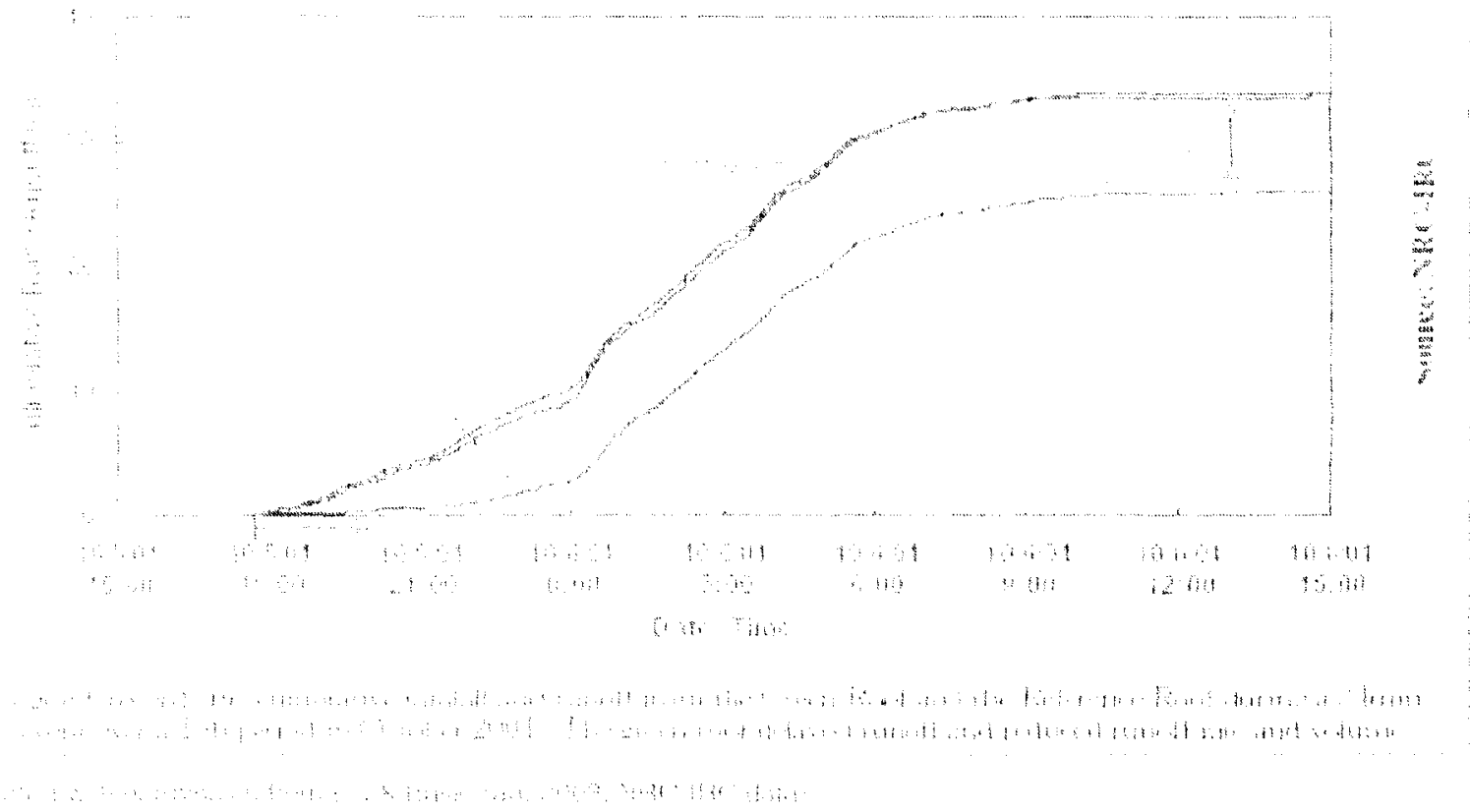

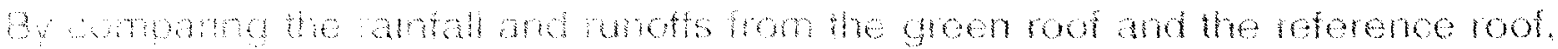

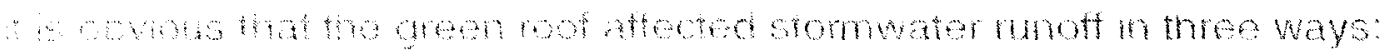

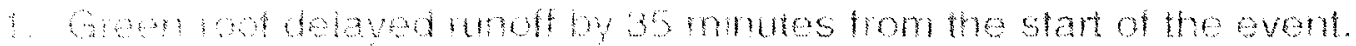

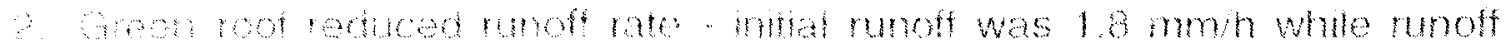
tron the gresn wot was reduced to 0 smmth. The reduction diminghed

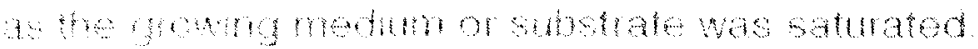

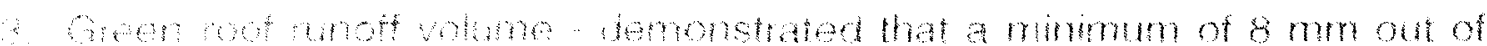

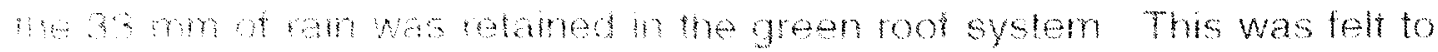
bo a comonam number as the growng medum was not dry lo begin whin $(9,3)$

\section{Toronto}

in November 2003 ww exensve groen roo research sites were established in Fonto Ontano one athe omputer science butding at Yotk University and the

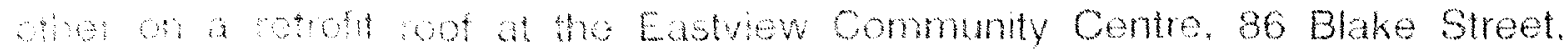
Fonnte. Besench is funded by Toronto and Region Conservation Authority, the Cty of Tomto a Faterat Gron Roof Systems Consothim and Green Roofs for 
Healthy Cities, a non-profit clearinghouse in Toronto (58). This research is also supported by the National Research Council, Government of Canada and particularly by, Karen Liu, the principal NRC construction investigator. The York University and Eastview Centre extensive green roofs are instrumented and connected via a web-based monitoring system (hardware and software) with real-time monitoring of all climate and hydrometric parameters. The system collects signals from sensors and stores and publishes them through the website. The green roof research site at York University is approximately 500 meters square (5000 sq. $\mathrm{ft}$ ). It has two test plots, one with vegetation and one as the control where each plot is approximately 100 meters square. Specific vegetation and substrate characterizations as well as irrigation and storm runoff storage tanks have been installed as part of the study. The slope of the roof garden is approximately $10 \%$. The ability to quantify stormwater data in Toronto is a principal research aim of the York University facility, as results from this site will inform decision makers at the Toronto Regional Conservation Authority and City of Toronto watershed management offices (58).

\section{Vancouver}

A modeling study in the Greater Vancouver Region (GVR) demonstrated that green roofs can protect streams and reduce flooding risk in mountainous urban regions. Researchers there developed a scenario-modeling tool, the Water Balance Model (WBM) ${ }^{\mathrm{TM}}$ in order to evaluate the performance of green roofs (28). Their modeling efforts show that green roofs are potentially very effective at reducing the volumes and peak rates of runoff from heavily developed areas in the GRV, especially in the southern parts where rainfall is typically lower. Vancouver-based research reports that even thin extensive green roofs were effective at reducing peak runoff rates during short high-intensity storms such as summer 'cloudbursts'. An inventory of Vancouver's green roofs revealed that there are many more extensive than intensive green roofs (19). Thicker intensive green roofs were found to be more effective at mitigating runoff from prolonged winter Vancouver storms (28). These researchers predict, based on modeling 
souts tron a soycar waterhed retroh scenaro. that re-development of

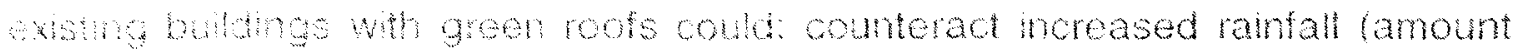

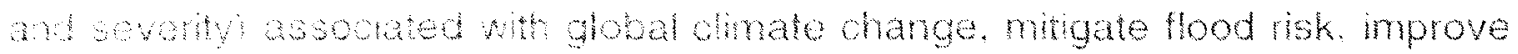
nater oraty an prevent turber degadation of fish habitat. This is especially Govat no wban pamers are wokng with the assumpton that the GVE population chutid cowble in the next 50 years (33).

Hancuer stomwwer research reveals hat:

3. Fnot volumes decrease with increased sol depth but tend 10 diminish atter about 10 crn espectally for higher rantall locations (figure? and 3 ).

2. about $25.30 \mathrm{~cm}$ of sol depth is needed to stabilize runolf rates from large prolonged whiter stoms inat rypically occur in the region (figure 2).

3. Sighicant reductons in runot rates result from short intense storms (ie. cout bursts that ocou in dry weather periods $\mathrm{n}(10 \mathrm{~cm})$ of sol depth figure 3

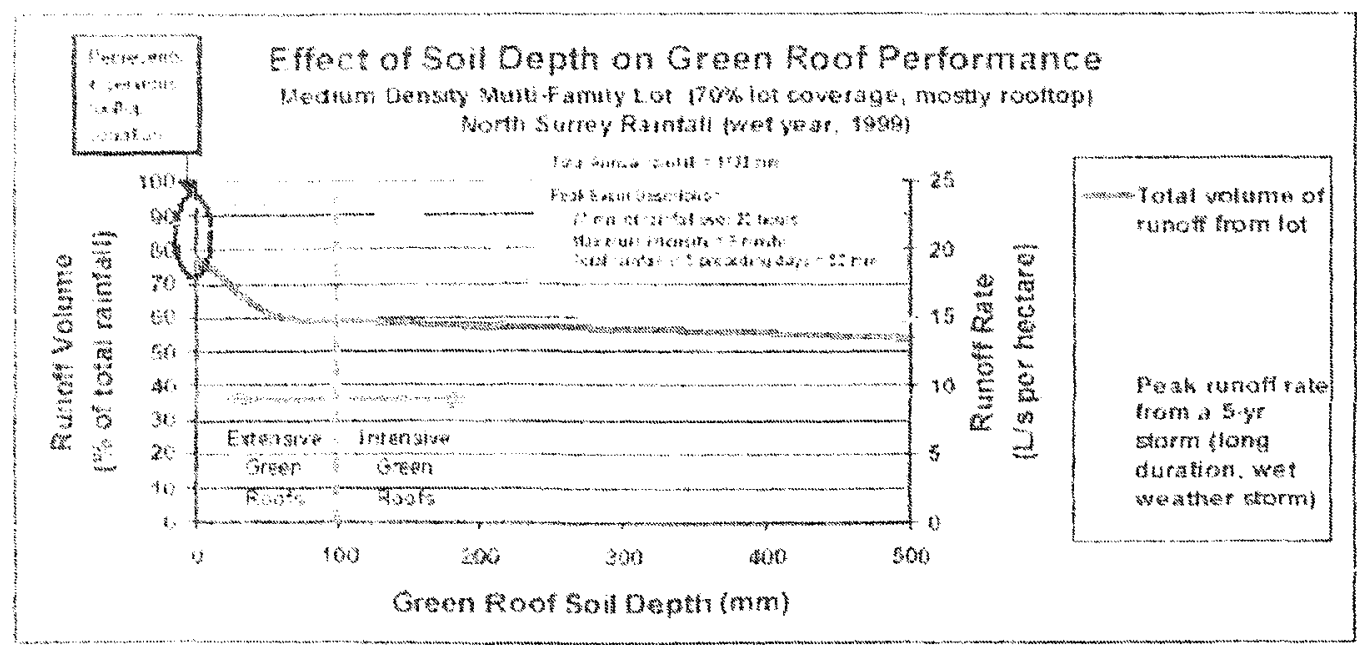

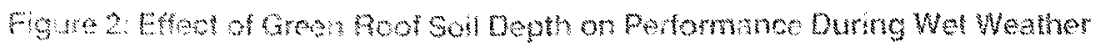

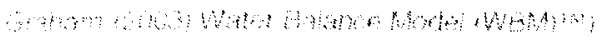

According to this lesearch, green roofs provide more significant reductions in numf volumes whe total annual rainfall depths are lower in average ffigure 4 below. The nunf volumes achieved by green roofs appear to be directly related 
to the amount of evapotranspiration that hes occured from the rooftop plants. Their modeling illustates that as the total anmual ramall decreascs, potential evepotranspitation becomes more significant relative to total raintall. These researchers suggested that green roots would be most effective in drier pats of the GVR (White Rock or Delta) in cher years as opposed to wetter years.

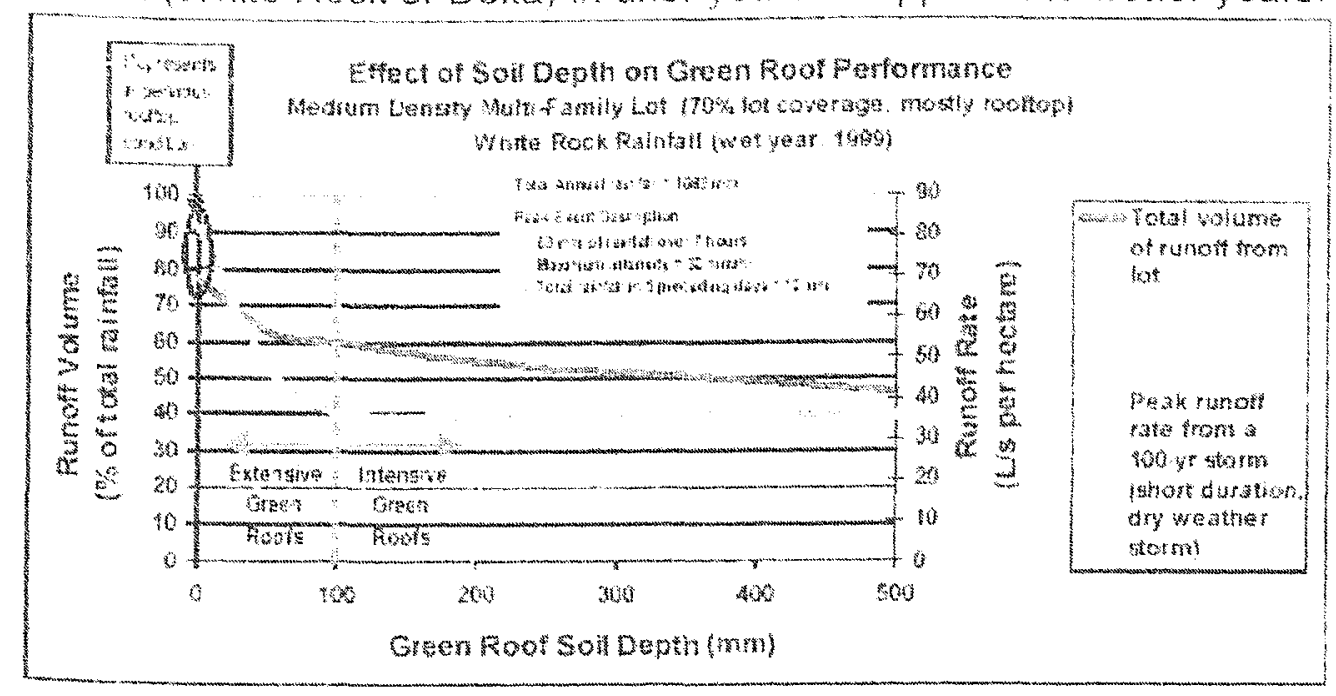

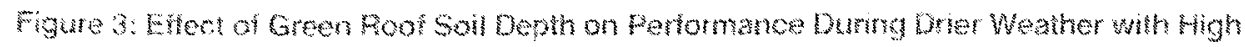
intensity cinudburstas

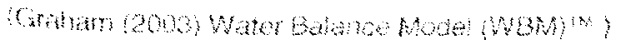

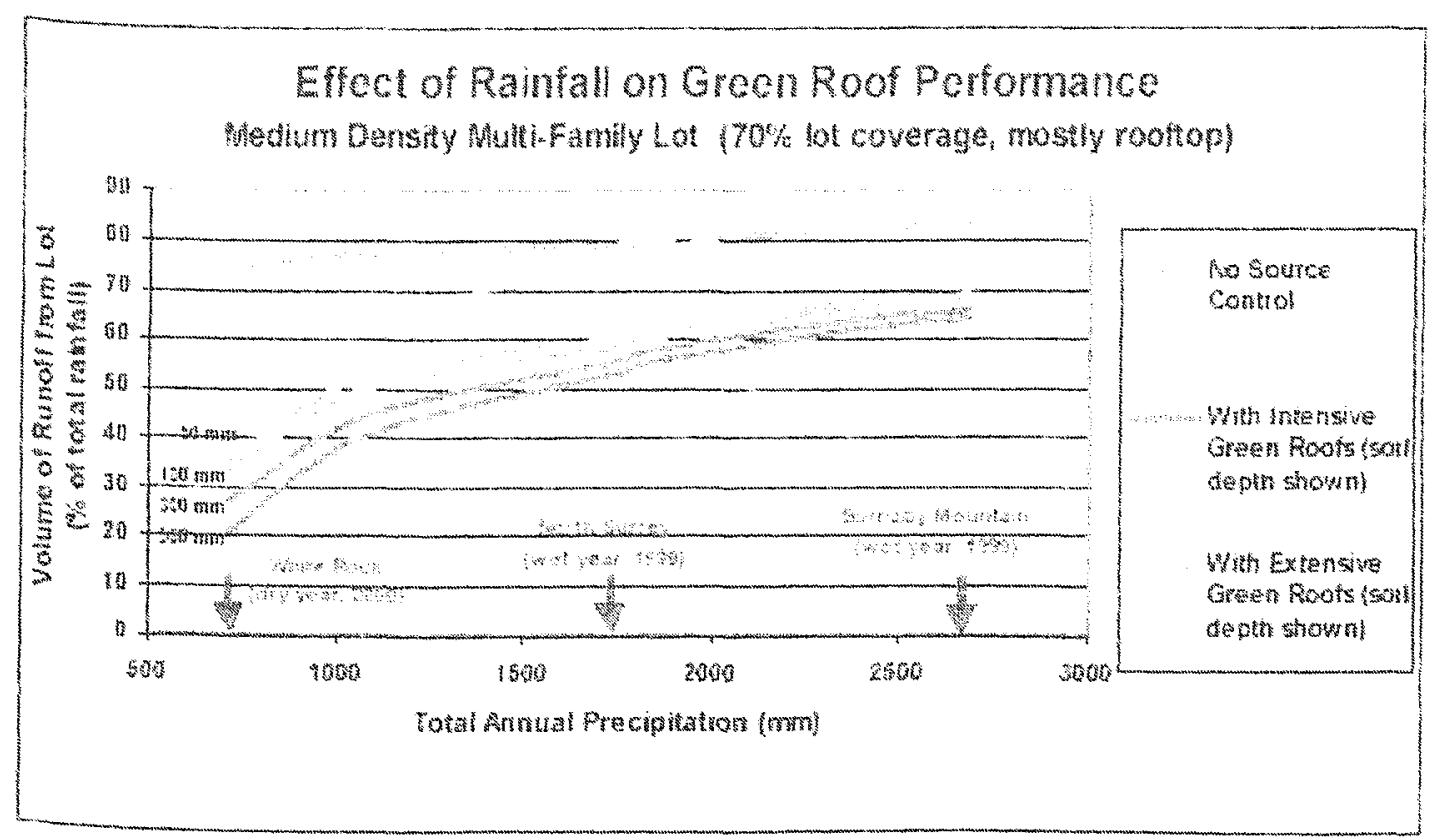

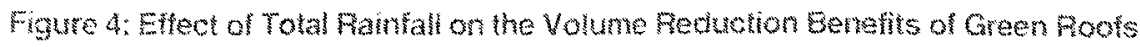


Graham suggested that the green roof-related reductions in volume and rate of runoff are probably most significant when planned for dense urban areas, such as those with a higher ratio of roof top coverage to ground level impervious areas, such as high-density multi-family or commercial buildings without substantial parking lot surfaces (33).

\section{Urban Heat Island Effect}

Urban heat island (UHI) is a phenomenon that results when green vegetated land areas are replaced by non-porous surfaces typically found in cities (26). Urban heat islands occur when the summer sun's ultraviolet rays are absorbed by dark, impervious urban surfaces and radiated back into the air as heat energy. Hence, many cities in the USA and Canada generate downtown air temperatures that are as much as 5.6 degrees Celsius warmer than their surrounding rural areas (8). When trees and vegetation are removed from a city, the natural cooling effects of shading and evaporation of water from soil and leaves (evapotranspiration) is lost. As previously stated in the section on stormwater management, plants provide a source of moisture through evapo-transpiration, or the movement of water back into the atmosphere as water vapour. Urban heat islands are created when solar energy is trapped in non-porous surfaces and released as heat throughout the day.

"Greater partitioning of absorbed solar energy into evapotranspiration reduces the amount of energy stored in urban materials and released as heat, thereby reducing the temperature of the vegetated surface and the low-level air" (8, p. 45).

Tall buildings and narrow strzet corridors can trap hot air that further reduces and restricts natural airflow. In addition, waste heat energy from cars, trucks, factories, cooling towers and air conditioners adds more heat to the urban air and contributes to urban heat island effect $(3,6)$.

Typically, heat islands are influenced by a city's proximity to water and the direction of the prevailing wind conditions. In Toronto, offshore winds and rain 
can 'flush out' hot air from the city center and reduce the heat island effect. On the other hand, sunny windless days can exacerbate the heat island effect, as hot polluted air is trapped in the urban core of Toronto $(6,7,3,4)$. Higher temperatures associated with the heat island effect act to threaten public health, as noted by several speakers at the Toronto Urban Heat Island Summit (8). Chiotti reported that there are specific health risks associated with living in the urban heat island effect such as stresses associated with high summer temperature, poor summer air quality and exposure to UV radiation. These stresses were reflected in increased morbidity, increased hospital admissions and increased death rates related to exacerbations in respiratory and cardiac conditions. While heat-related mortality is difficult to measure Chiotti estimated that the total death rate from hot summer temperatures in Toronto ranged from $9.63-33.65$ per 100,000 population during summer heat waves (17).

Currently, the literature reveals little primary research on the effect of green roofs on urban heat island effect beyond a significant reporst by Bass, Akbari and Konopacki $(2,3,8)$. Bass cites other authors, who compare temperatures between various urban surfaces. For example, summer temperatures on urban paved roads ranged between 45 and $60^{\circ} \mathrm{C}$ compared with surface temperatures in forests, wooded areas and grasslands that fell below $30^{\circ} \mathrm{C}$. While intuitively this work and others would support a vigorous urban tree planting policy to reduce urban heat island effect, Bass posits that green roofs are a more realistic urban planning tool for reducing surface temperatures. One reason is that urban roof surfaces are plentiful and, in many cases, unimpeded by overheard wires, streets, sidewalks or paved surface areas (8). Data collected from conventional gravel and tar roofs suggest day time temperatures can reach between $60-80^{\circ} \mathrm{C}$; hence, when one adds up the thousands of square feet of conventional roof coverage in Toronto, it can be argued that conventional roofs are exacerbating the urban heat island effect and the vertical movement of suspended particulates, dust and pollutants into the local atmosphere within the city $(3,9$, $18,23)$. 
According to Bass urban heat island exists in different layers, one of them being the urban boundary layer (8). This is a layer extending roughly from the rooftop level up to the level where the urban influence is no longer felt. Temperatures in the boundary layer can impact temperatures at canopy level, that is, the level where most people live. The temperature and chemistry in the boundary layer drives the several chemical reactions that create ozone and further degrade air quality levels. It is speculated that summer temperatures on rooftops at high elevations can affect the chemistry occurring in the boundary layer.

Conventional rooftops are often hotter than surrounding grade level temperatures $(3,6,8)$. This finding not only exacerbates the urban heat island effect but also serves to heat up the top floors of tall buildings, homes and office structures. In turn, higher temperatures in buildings cause discomfort to tenants or occupants, especially on the uppermost floors. These warm temperatures exacerbate a reliance on fossil fuels to power air conditioning units that make conditions more tolerable inside buildings. Concomitantly, warm temperatures cause an increase in the electricity demand for refrigerators that struggle to maintain cool temperatures in tall, hot buildings. Overall, building energy demand increases due to the added solar thermal load that is transferred through a conventional roof into the uppermost floors of a building (95). As such, rooftop heat loading and increases electricity demand from local coal-fired generating plants with a resultant increase in emission of air pollutants including, greenhouse gases, nitrous oxides and particulates $(8,3,53,54)$. Conversely, reviews by Wong et al. and Kohler et al. have shown that indoor temperatures under a green roof system are at least $3-4^{\circ} \mathrm{C}$ lower than outside temperatures of 25 to $30^{\circ} \mathrm{C}(47$, 115).

In order to accurately model Toronto's urban heat island, Bass (2001) utilized a mesoscale meteorological model called the Mesoscale Compressible Community Model (MC2) (6). Bass reported that the during testing, the model revealed a 
weak urban heat island in Toronto, and this had implications for the overall green roof effect on surrounding air temperatures. Toronto's green roof coverage was modeled as $5 \%$ of total land use and was spread evenly over the city. Bass was able to examine commercial and residential high-density areas in Toronto and add irrigation to their green roofs by modeling the effect of irrigation at ground level. When irrigation was added to $5 \%$ of the green roofs, the temperatures were reduced by at least $2^{\circ} \mathrm{C}$ over the green roof areas. Studies on thermal movement of air have shown that there is less vertical air movement over grassy surfaces (106). According to the work of Minke and Witter grassy surfaces do not heat up to more than $25^{\circ} \mathrm{C}$. This is mostly due to the fact that with evapotranspiration there are large amounts of solar radiation converted into latent heat which prevents the temperature from rising $(67,106)$.

\section{Urban Heat Island and New York City}

The New York City Ecological Study (NYCES,) started in New York City in 2003, appears to be one of the most sophisticated studies of the green roof effect in North America. Currently, Phase 1 involves the completion of a cost-benefit analysis of green roof development (1). Other green roof components of the study include an analysis of: urban heat island; energy and regional warming; hydrology; health impacts; building and urban infrastructure; and policy. The urban heat island research is conducted by Dr. Cynthia Rosenzweig of the NASA Goddard Institute for Space Studies, Dr. William Solecki of Montclaire State University and Dr. Stuart Gaffin of the Columbia Earth Institute. This team plans to document the existence of the New York City urban heat island by comparing meteorological station data in urban and suburban regions of the New York metropolitan region. They plan to present their multi-year findings at the International Greening Sustainable Cities conference in Washington 2005 (30).

These researchers have developed a regional climate model that has been used to test the role of green roofs as "cooling engines" and "runoff traps" for the region as a whole. Using loca! New York City scenarios, they plan to conduct an 
analysis of how temperature, urban heat island, cloud cover and wind speed might change over the region in response to global warming; results may provide further justification for green roofs as a useful urban adaptation strategy. Finally, these researchers plan to make linkages between green roofs and temperature reduction, air quality and energy benefits apparent by modeling scenarios that demonstrate simple green roof results can be aggregated to form neighbourhoods that will help to estimate long-term changes to the city's temperature, air quality and building energy consumption rates (16).

\section{Building Roof Membrane Performance}

The Ottawa-based National Research Council, Institute for Research in Construction, Field Roof Facility work collaboratively with the North American Roofing Industry, in support of green roof research on building performance. These researchers have examined building energy parameters and roof membrane protection studies. Liu suggests that green roofs not only protect roofing membranes from damaging weather and heat conditions, but most notably, green roofs reduce membrane exposure to intense ultraviolet (UV) radiation (54). In effect, vegetation on green roofs serves to moderate temperatures along the roof membrane so that daily fluctuations in temperature are less damaging to the structural matrix or integrity of the roof membrane. Similarly, green roofs shade and protect the roofing membrane from extreme fluctuations in temperature that follow the hottest summer days and the frigid temperatures in winter conditions. According to Liu and other authors, temperature fluctuations lead to the micro and macroscopic contractions and expansions within the membrane layers, which promote cracking and premature aging of the membrane $(54,99,80,95)$. The lifespan of consentional roofing membranes is predicted to be 20 years $(19,21,27,60,62)$. Some authors accept that green roofs extend the lifespan of the roofing membrane to an estimated 40 years (28). According to European researchers Liesecke and Johnson a London (UK) department store installed a green roof in 1939 and 50 years later the membrane was inspected and found to be in excellent condition 


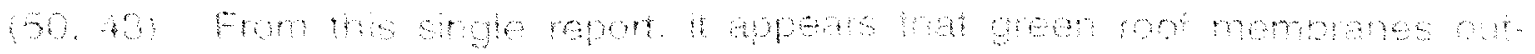

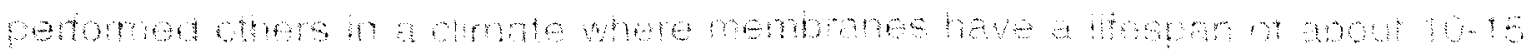

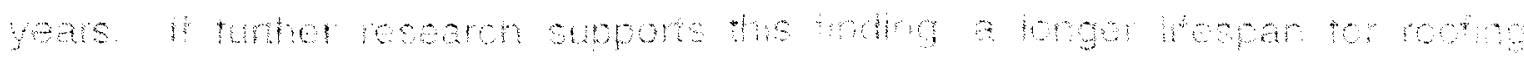

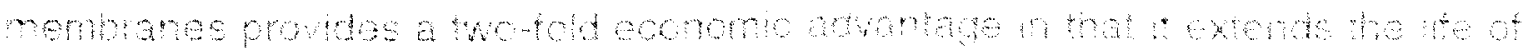

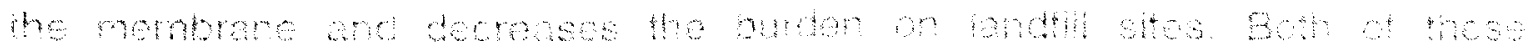

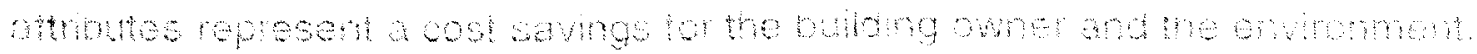

\section{Buildng Energy and teat Fhx}

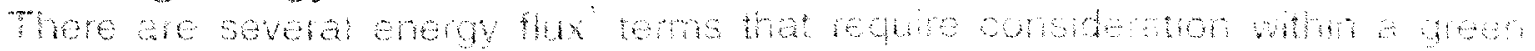

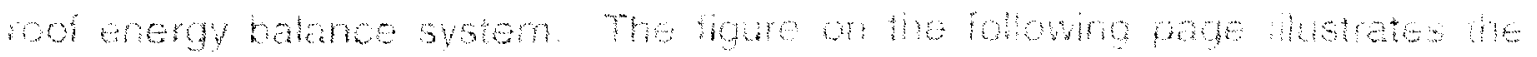

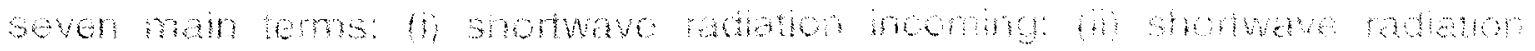

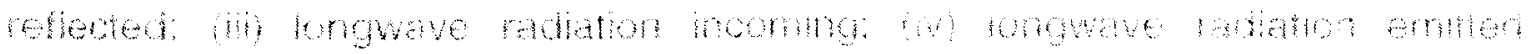

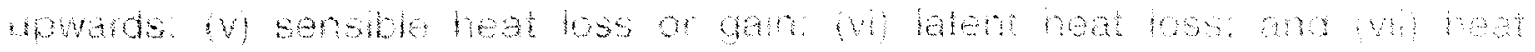

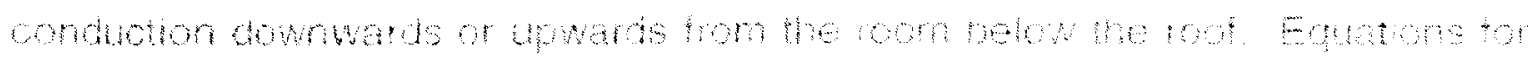

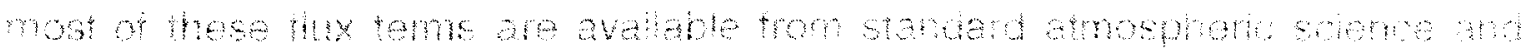

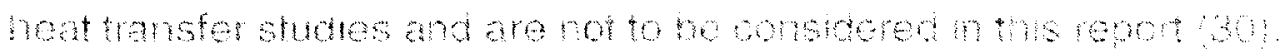

\section{Figure 5: Basic roof energy balance}

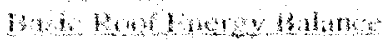
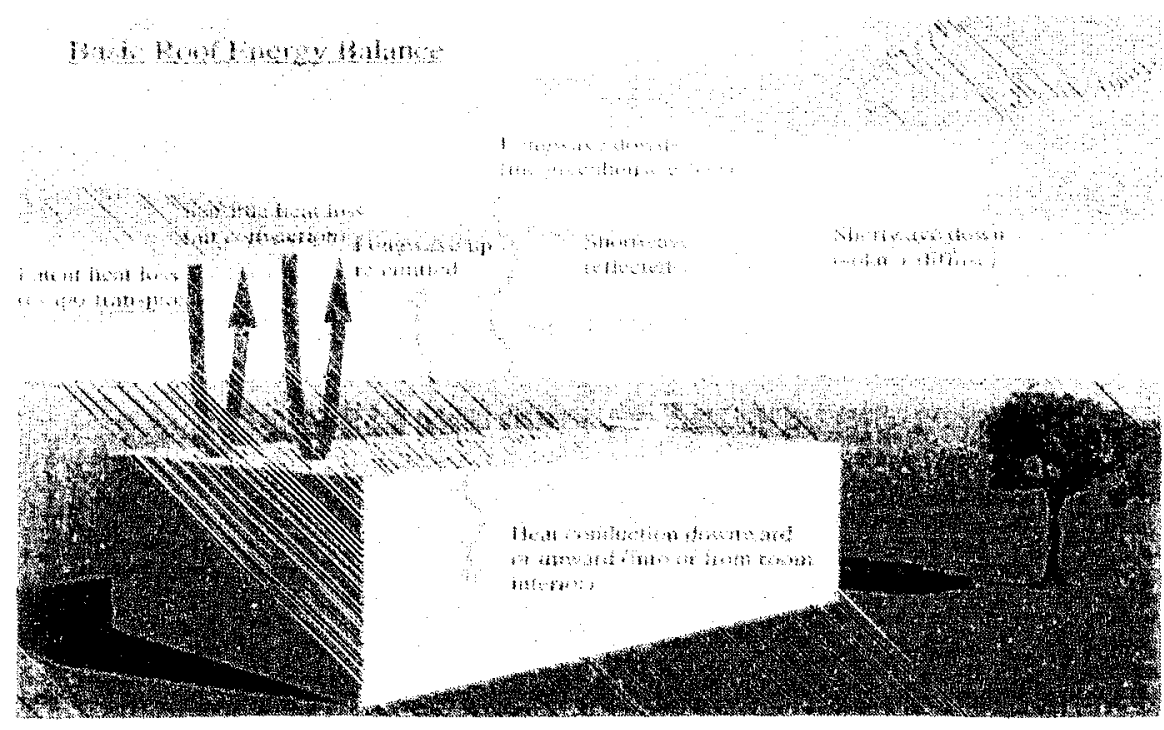

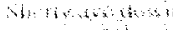
ins

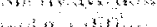
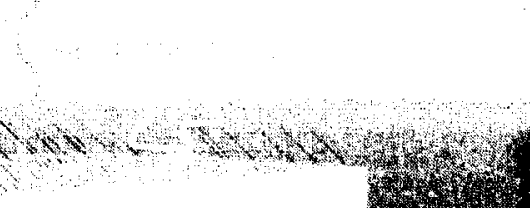

What a

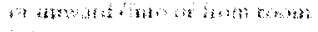
mit? 


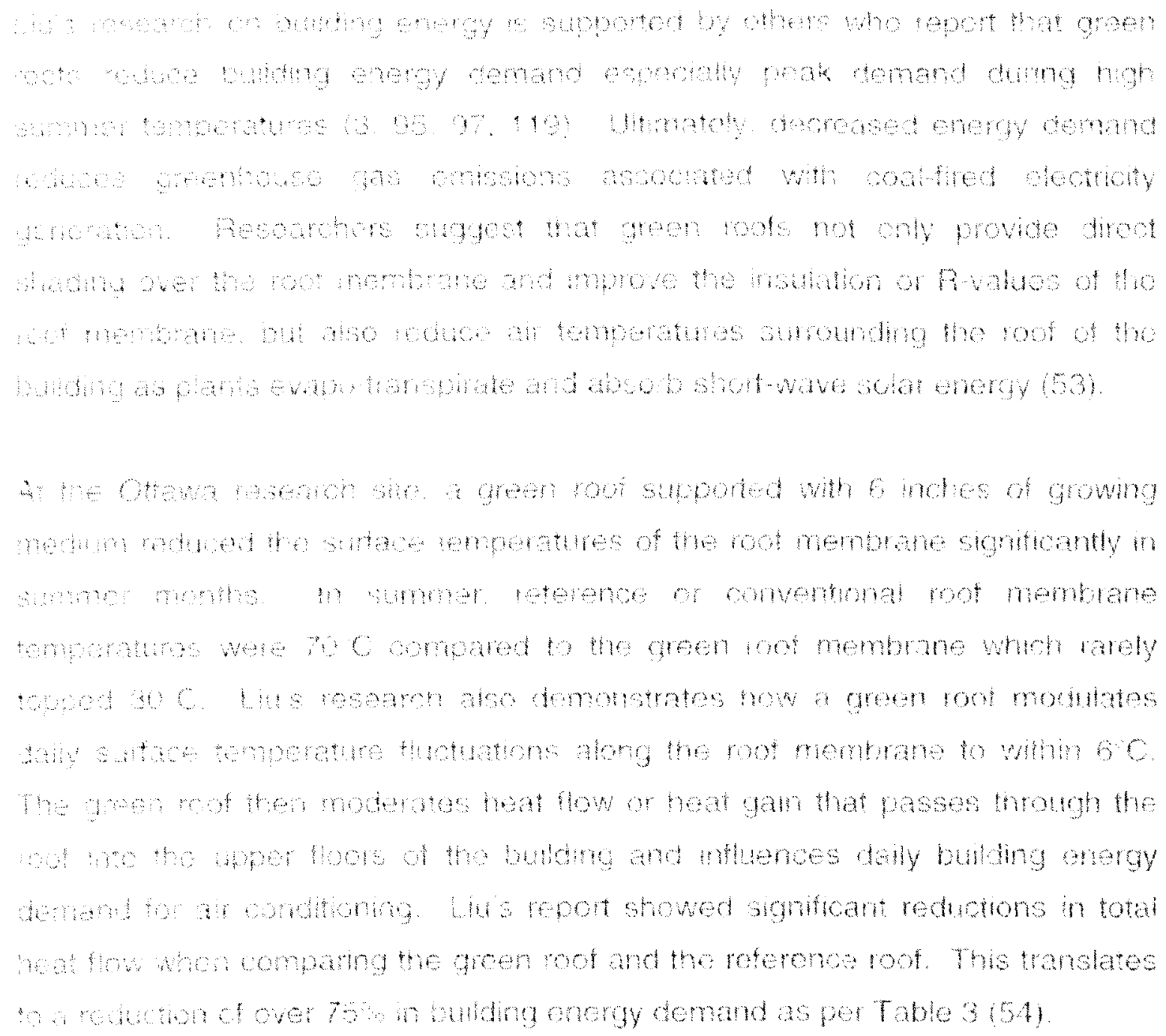

Table 3: Thermal comparisons between reference and green roof. Ottawa şte

\begin{tabular}{|c|c|}
\hline & Peference Rool \\
\hline Heat Gam & $103 \mathrm{kWhm}$ \\
\hline Heat Loss & aA.1 kWmm \\
\hline kat Heat Flow & $63+4$ Whm" \\
\hline
\end{tabular}

\begin{tabular}{c|c} 
Green Root & Peduction \\
$09 \mathrm{kWhm}$ & 95 \\
$328 \mathrm{kWhm}$ & $26^{\circ}$ \\
$33.7 \mathrm{kWhm}$ & 47
\end{tabular}


Heat fluctuations between roof membranes in the figures on the following pages illustrate that there are notable temperature differences between the conventional or reference roof and the green roof. A significant thermal benefit is provided by the green roof and fewer kilowatts of energy are required to maintain indoor temperatures at a steady state. The next three figures are adapted from Lui and Baskeran's research at the Ottawa research facility and show comparisons in heat gain and heat transfer between the green roof and the reference roof. The figures also illustrate the differences in thermal benefit between a green roof and a reference roof (54). 
sin

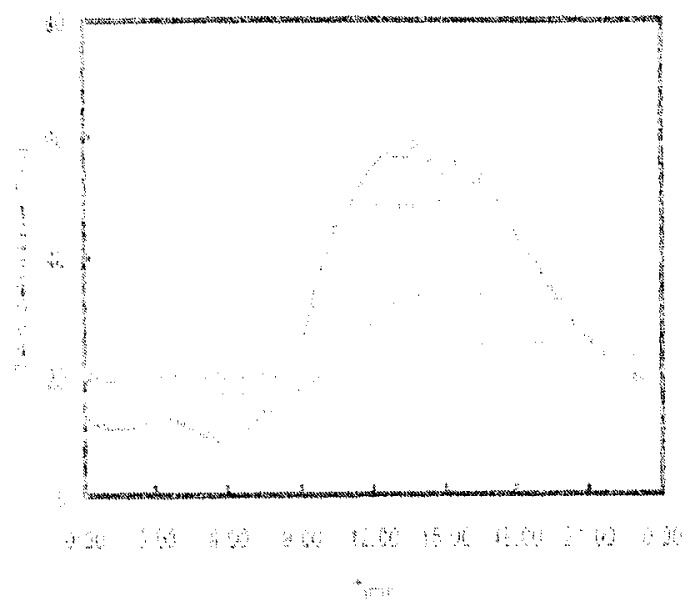

ising

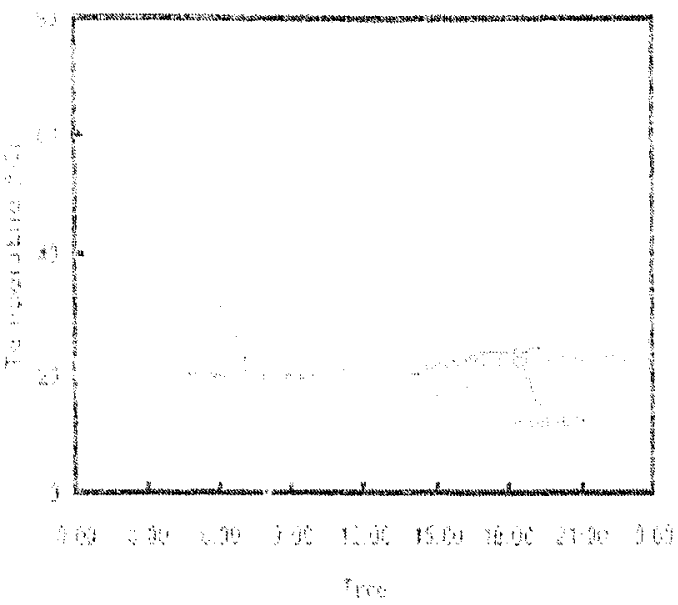

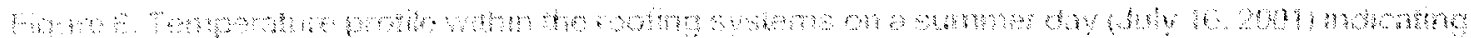

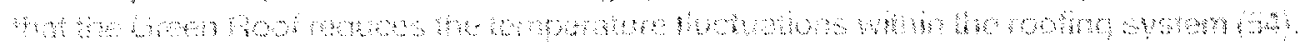

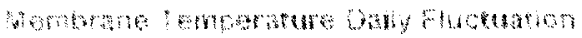

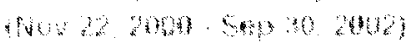

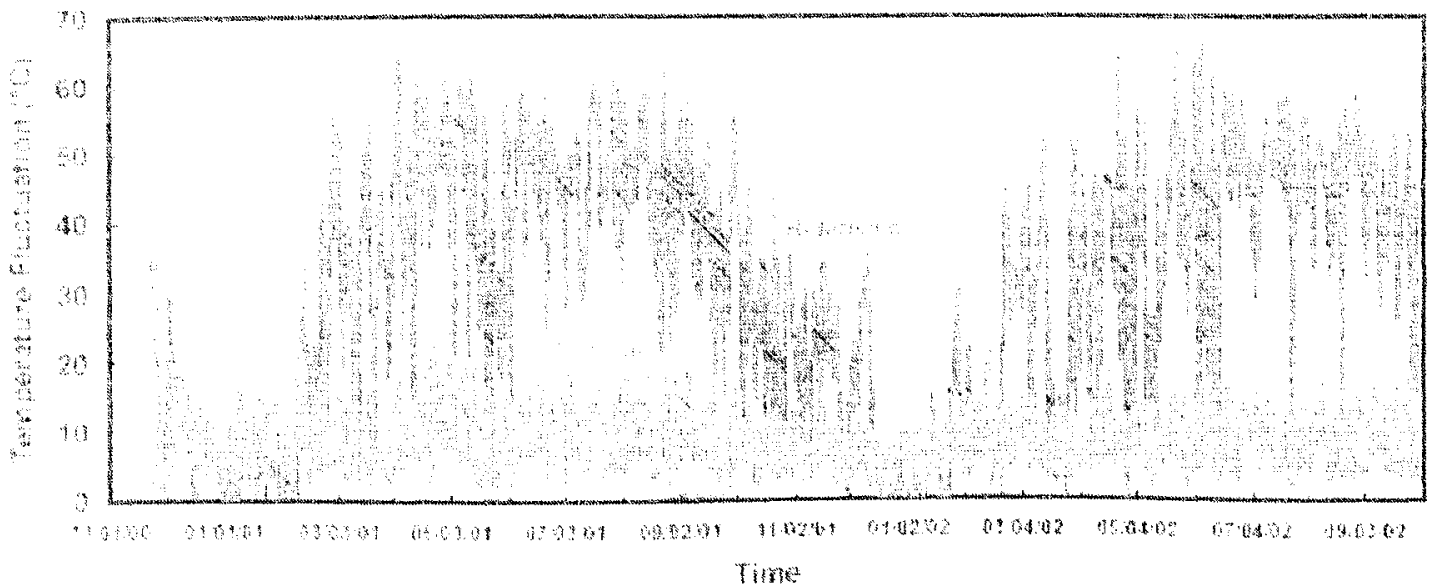

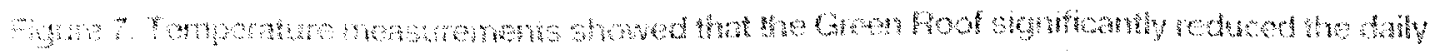

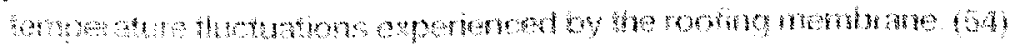



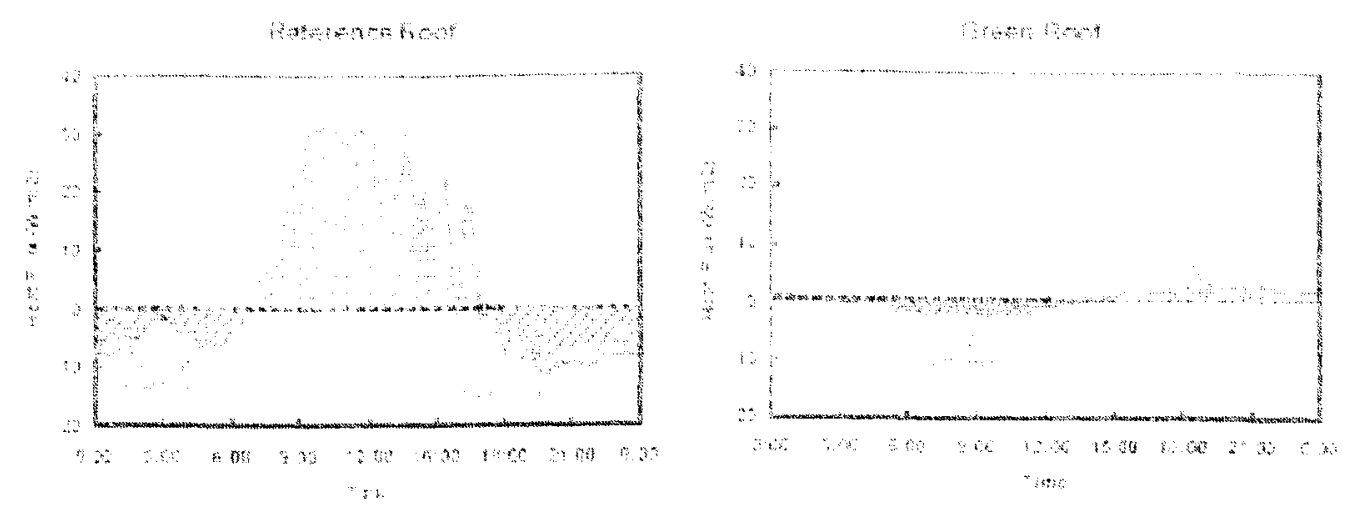

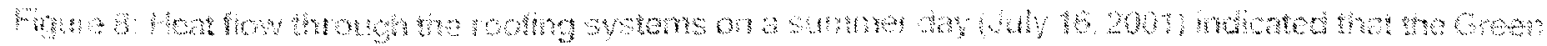

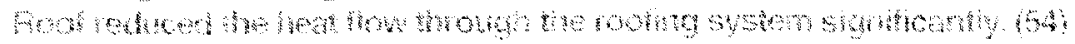

These Otrava studies are suppored by a consontum of researchers at the Natonal Unversty of Smgapone Centre for Total Buiding Pertomanoe and the

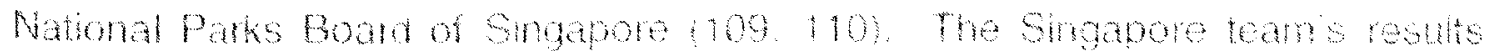
strenghen provous findings that heat gan thumgn the roof under the green roof Was sgntwonty reduced compared to an exposed leterence not. In shropore. exposed paved root potwons peked at $57 \mathrm{C}$ with dimal thewations up to 30 C. In contrat the temperatues under the folage of vatious low pam speces peaked at $27 \mathrm{C}$ whth a maxmum duma huchation of $3 \cdot \mathrm{C}$. The vegetated rootiog also reduced ambint an temperature the mean redant lemperature and the temperature of reflected radation to the ambient emvitoment. This study suppors othe evidence that rotop gardens can mitgate the urban heat istand effoct that may be more accentuated in a trophal clinate (30.97).

A study by Saz and Bass (2005) described how the ESP. model (Emirommental Systoms Pefomance - research ilustmated the effects of ateen roots on buiding energy demand in a muli-storey restdence $n$ Madrid span in sumer and whiter condition the annual energy consumption was calculated for ths residence acooring to thee diterent scenaros a basio fat root (FP) a green roof (GR), and a Alibe root (AR). Alibe reters to Spanish green roof tochmology 


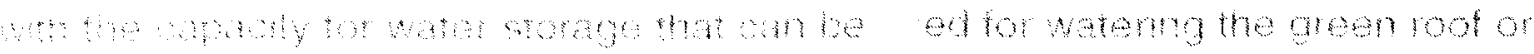

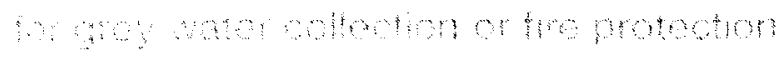

Table 4: Comparison between the total anvul energy consumed for hearing and cooling

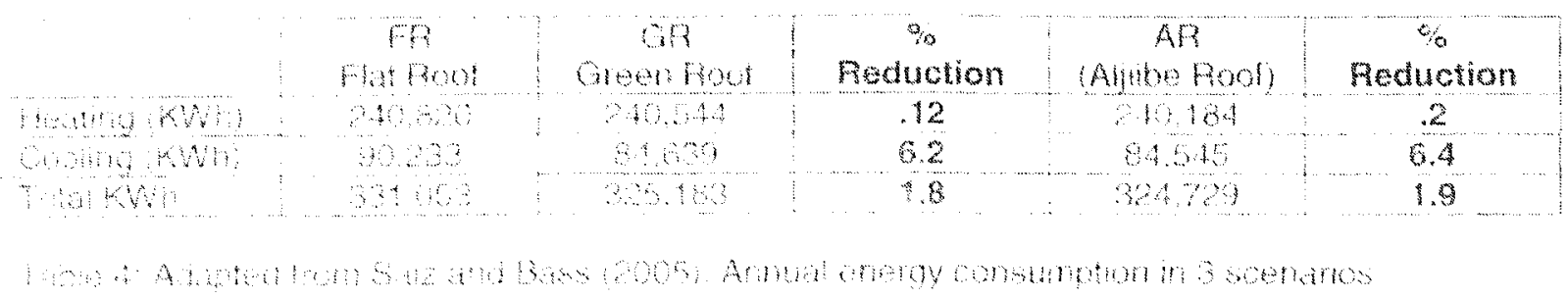

The rewtion m energ consumption are hue to the combined effect of lower

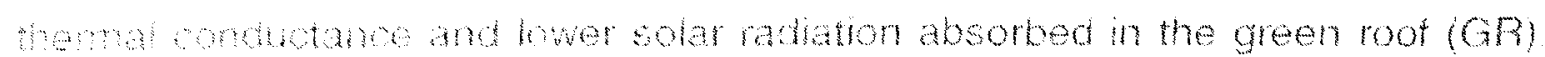
Eve" moun the onary savigs can be considered small tess man 20 , in is nownty that the handmg toot ara was only 16 of the lotal buding and

Omma et conducted field measurements on a series of planted roots in Gom (s2) They repoted that an evaporative cooling effect created by the oftop law garden showed a $50^{\circ}$ reduction in heat flux into the rooms below the genden Their researh repored a reduction in surtace temperature from 60 S to 30 dung the day and heped to strengthen the role played by heathy plants and evpo-transpiation m reducing the butding heat flux.

\section{Peak Energy Values}

saz and Bass (2005) examined the effect of green roof systems on a building's peak enegy onsumption in summer. in Madrid. Span. The resultant total oncry consumption tor the pow days dropped by $12 \%$ under the green roof systene commared to a common flat roof. Two vypes of green roof systems - a bpol geen roof (GA) and an Ajbe roof (AB) - had diferent conductance values $10^{\circ}$ bwer in the AR) but the difference in energy consumption between these cases was amost negligible (1\% lower in the building with the AR). These 
results show the reduced effect of differences in the thermal roof conductance values on the overall thermal performance of the building and highlight the significant role of green roof vegetation in absorbing solar radiation, especially during peak energy consumption.

Saiz and Bass calculated peak energy consumption for each zone in a multiresidential building to evaluate the effect of the green roof on building energy consumption within floors of the building (figure 9) (97). They reported that energy flow is not uniformly distributed in buildings and that the reductions in peak energy consumption throughout a building vary from floor to floor. The largest reduction in cooling energy consumption of $25 \%$ was achieved in the floor directly under the green roof. From there, the cooling effect progressively decreased from the top floors down to the basement of the building.

Figure 9: Summer cooling reductions achieved within multi-story building

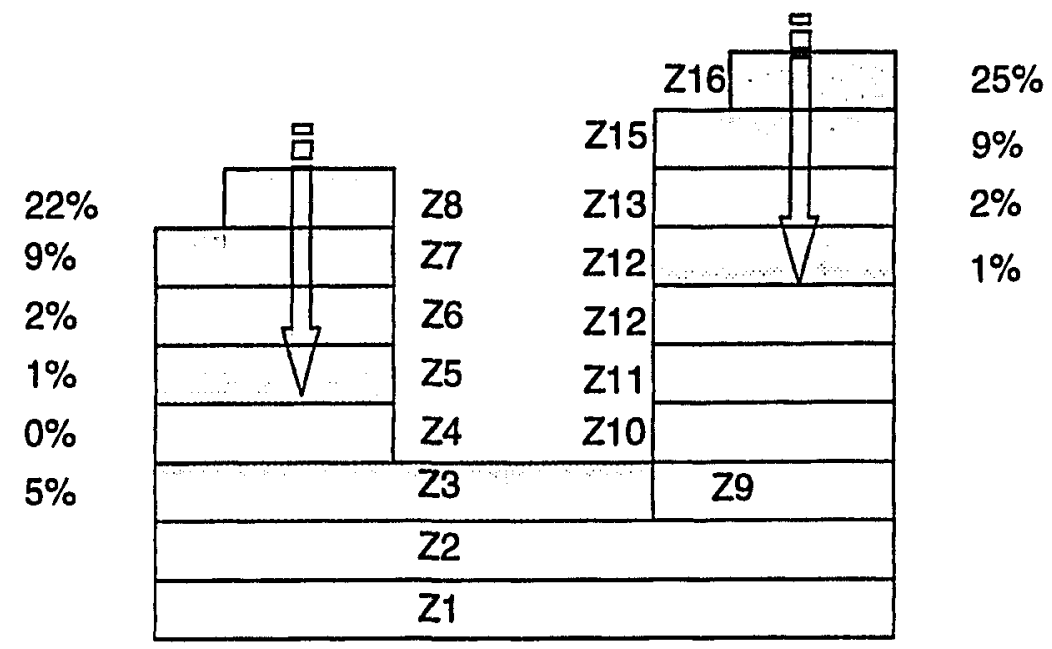

(Figure 9: Adapted trom Siaz and Bass (2005). Peak summer cooling energy reductions achieved within the 8 storeys of the study building. A green roof is located over zone 8 and zone 16)

Building energy savings are predicted to arise from green roof vegetation in the following ways: it absorbs solar radiation; it shades the roof membrane; it increases the thermal resistance of the membrane; and it provides a cooling effect by releasing moisture in evapo-transpiration. Of note in this study, a green 
roof added to merely $16 \%$ of the building roof surface resulted in a total annual energy consumption reduction of $1 \%$ in the heating season and a $6 \%$ reduction in the cooling season. However in the upper floors, a significant energy reduction of $25 \%$ was noted during the peak summer demand and $12 \%$ during the winter (97).

\section{Habitat Restoration and Conservation}

A dictionary definition for habitat suggests that it is a specific surrounding within which an organism, species or community lives. It includes physical elements (temperature, humidity, moisture and light) biological factors (species diversity, breeding partners) and the presence of food and predators $(59,93,43)$. As urban development encroaches on surrounding habitats like rivers, wetlands, forests, meadows and grasslands, these habitats can be extirpated or destroyed. Loss of habitat threatens species evolution, differentiation and survival of native plants, animals and insects. Green roofs provide an elevated vegetated platform that may in time serve as an adapted urban habitat for some of the displaced native plants, animals and insects.

Green roofs as habitats are being studied in Europe (13, 32, 31). Green roofs have been found to be stepping-stone habitats that can connect natural isolated pockets of biodiversity to one other. This is particularly valuable when isolated communities within a green roof can communicate with each other overland using bridges provided by logs or sticks. Green roofs can also be reached by air pathways that can be used by migrating birds, nesting birds, insects and airborne seeds. Researchers suggest that green roofs serve as connecting habitats as part of a larger system of wildlife corridors that protect species within urban areas across Europe $(13,14)$. Studies available on habitats at elevation describe them as isolated or island habitats, as compared to habitats at grade level. Green roof findings to date support the notion that island or rooftop habitats have become home to specific plants whose seeds have blown there or have been 
deposited by visiting birds, invertebrates and other animals that can climb to access the green roof $(13,14,31,32)$.

Green roof studies in Switzerland and Canada have revealed that urban green roof habitats can mimic endangered ecosystems and restore habitat for species that were thought to have been lost to development and urban sprawl $(11,13$, 14, 25). In Germany, over $20 \%$ of all endangered plants are arid/semi-arid grassland plants. These species are resistant to dryness, intense heat, frost, intense sunlight and wind - ironically all the conditions which prevail on a green roof. Habitat replacement for species at risk on green roof installations is a direction that ecologists and green roof planners are promoting $(25,29)$. Green roofs support many different prairie grassland species throughout the Midwest United States $(60,73)$ while others in Canada support rocky alvars from the Great Lakes Region $(87,90)$. Green roofs on the Mountain Equipment Co-op and York University Computer Science Buildings in Toronto, Ontario support prairie meadow species and several native Ontario grass species (87).

Frith and rarell of the UK's Greater London Authority Regeneration and policy team state:

"green roofs of all types attract some wildlife. Natural colonization by a variety of lichens, mosses, plants and animals will occur over time, although they will be dependent on the roof's size, shape, aspect, location, climate and the species' mobility and tolerance. The use provision of shelter, nest and roost boxes and voids will also help to attract wildlife. We are only just beginning to realize the benefits of greening roofs for biodiversity." $(29,2003$ p. 5)

Brienneisen's studies on biodiversity report findings of rare and common insect species on green roofs. This research is the most comprehensive to date on the study of habitat and biodiversity. Bitenneisen studied samples of 11 extensive green roofs and found 172 species of beetle (10\% of them in the Swiss Red Data Book of rare species) and 60 species of spider ( $40 \%$ of them equivalent to the Swiss Red Data Book) $(13,14)$. This research marked that older roofs had 
species types and more numbers of species compared to younger newer roofs. Similarly, roofs with greater structural diversity or variances in topography (rocks, sticks, logs, berms, and other changes in elevation among the substrate) revealed the most diversity among species and a higher density of beetle species. This research also showed that the ability of the roof to retain water was a key factor in attracting species and that the number of rare beetles and spiders was increased on green roofs by varying the depth of substrate $(13,14)$

Extensive green roofs also offer safe havens for butterflies, which have been observed on roofs as high as $19^{\text {th }}$ to the $23^{\text {rd }}$ floor in England (43). English Nature), the British Government's Advisory Body on nature conservation, commissioned an invertebrate survey on existing green roofs across England (29). The study identified 14 animal species on green roof habitat and spawned a research group called 'Green Roofs for Black Redstarts' (31). This research partnership seeks to address the issue of conserving biodiversity and black Redstarts in London by rotecting brownfield land and the substrates therein that contain native seeds, invertebrate colonies and nesting grounds for Black Redstarts. Brownfields are the contaminated industrial lands that, according to the Government of the day, are preferred choices for development in preference to 'green land' which surrounds cities. There is an assumption that protecting green space is a better mechanism for supporting wildlife. Research by Gedge has shown that brownfield land is often more diverse than green field land (31). Gedge and the UK-based Biodiversity Partnership are asking green roof developers to consider utilizing brownfield substrates for green roof planting media $(31,32)$. The Biodiversity Partnership advocates for the use of industrial waste material as part of the green roof planting substrate and that it be allowed to rest at the building site during the early building phase. By resting the industrial waste on pallets close to the building site (at grade level), a local seed base and available invertebrate species can access the soil, build up and colonize once elevated to the roof. Othenwise, it is very difficult for some species to colonize these aerial locations. This ground level colonization process ensures that the 
local biodiversity in the brownfield site are more easily replicated on the roof when the material is laid $(31,32)$.

The first such brown roof was constructed in Laban Dance Centre in Deptford and more are to follow across London. Another roof on the Creekside Centre, Deptford used a mix of crushed brick and concrete from a local source to provide the substrate base of the roof. In fact, this is how the black redstarts have been rejuvenated in London, England. Details of more than 15,000 square meters of green roofs are to be constructed for Black Redstarts over the next few years that are known about by the Partnership.

\section{Air Pollution and Green Roofs}

Research from the USDA Forest Service in Syracuse, New York, among others, support the role of urban forests, trees and shrubs in improving air pollution, reducing urban surface temperatures and improving property values in North American cities $(74,75,79)$. Little research to date has isolated or reviewed the effect of green roofs on air pollution when added to commercial, residential or institutional buildings in urban areas. As shown throughout the literature review, many North American green roof research facilities investigate the effect of varying prarameters on stormwater management, building energy and urban heat island eifects; however, few studies to date have examined the role of green roofs in reducing air pollution in urban areas.

\section{The Problem with Air Pollution}

A study by Toronto Public Health Unit (2000) estimated that exposure to five common smog-related air pollutants contributed to over 1,000 premature deaths and about 5,500 hospitalizations each year in Toronto. One of the major components of smog is ground level ozone, a gas that is created when nitrous oxides (NOX) and volatile organic compounds (VOCs) mix with the atmosphere in sunlight. The Ontario Medical Association (OMA) reports that each day in Canadian cities we are exposed to a chemical "soup" that contains several poisons, particularly, ground level ozone and particulate matter, otherwise known 
as acidic water droplets (83). The OMA estimates that air pollution costs Ontario more than one billion dollars per year from hospital admissions, emergency room visits and absenteeism. Health-related consequences of inhaling smog and particulates include; breathing difficulties, cardiac exacerbations, asthma, particularly in children, and sudden death, which peaks right after air pollution levels peak particularly in hot summer temperatures. According the OMA, levels of ozone and inhalable particulates are increasing in Ontario, despite warnings positioned at several levels of government. While public health responses to a predicted or sudden peak in air pollution levels can be planned at the municipal level, a bigger concern is the chronic, long-term effect of air pollution on residents in urban areas. It is well documented that air pollution can aggravate existing breathing and heart problems to such an extent that medical treatment is necessary (83). Of particular concern is asthma, which surrently affects about $12 \%$ of children and $6 \%$ of adults in Canada (118).

Toronto-based hospitalization data reveal that children account for the largest number of asthma-related hospital admissions. This finding circumscribes the vulnerability of children to air pollution (118). Health researchers have developed risk coefficients to estimate the economic costs or burden of illness, associated with the lost productivity, risk of mortality, hospital admissions, emergency room visits, doctors office visits, medication costs and decreases in quality of life associated with air pollution. When these coefficients are applied to Torontospecific data, the number of persons who are predicted to die or be hospitalized from air pollution levels contribute to about 1,700 premature deaths and 6,000 hospitalizations on an annual basis (118). This estimate is based on the health risks associated with exposure to ozone, nitrogen dioxide, carbon monoxide and sulphur dioxide, as well as the health risk associated with chronic exposure to fine particulates $\left(\mathrm{PM}_{2.5}\right)$. 


\section{The Economics of Air Pollution}

The OMA estimates that air pollution contributed to 1,900 premature deaths, over 22,000 hospital visits and some 47 million minor illnesses in the year 2000 (84). To better estimate the economic and health damages associated with air pollution, the OMA developed a model called ICAP (IIIness Costs of Air Poilution). In the year 2000, ICAP forecast that air quality in Ontario contributed $\$ 600$ million in costs to the health-care system and another $\$ 560$ million in direct losses to employers and employees. This represents over one billion dollars in direct costs to the people of Ontario (84). Conservative estimates of value for pain and suffering and loss of life add five billion and four billion dollars respectively to the total. These calculations predict a total annual economic loss of $t \in n$ billion dollars in $\mathbf{2 0 0 0}$ with a forecast that it will rise to twelve billion dollars by the year 2015 .

\section{Air Pollution and the Natural World}

While air contaminants are a risk to human health, so too is their effect on the health and viability of the natural ecosystem. Air pollution can impact the sustainability of all living things, but in particular the integrity of built form in urban areas, the health and viability of lakes, rivers, agricultural and food growing areas, as well as the health of animals, invertebrates, fish and forests (57). Climate change and atmospheric variability are predicted to generate severe weather events and precipitate more frequent flooding and summer heat waves in Canada. Warmer average temperatures in cities will trigger the chemical reactions involved in smog formation and potentiate a rise in greenhouse gas emissions from coal-fired electricity plants as buildings respond with surges in air conditioning demand. Environment Canada predicts that the number of days when temperatures climb above 30 degrees Celsius will rise from 10 to 50 days per year if atmospheric carbon dioxide levels double (57).

\section{Vegetation and Air Pollution}

In response to urban environmental problems some authors have studied the effects of vegetation, particularly trees, on cooling ambient urban air, shading 
buildings and absorbing gaseous air contaminants $(4,2,6)$. Researchers in Los Angeles measured the effects of tree planting and re-roofing in cooler colours, on ambient temperatures and air pollution. Their research confirmed that combining trees with cool roofs could lower the ambient temperature in Los Angeles by $3^{\circ} \mathrm{C}$ and cool the air surrounding buildings (4). Cooler air in urban areas is more comfortable and reduces the vertical movement of warm, polluted air, hence concentrating the smog precursors in smaller volumes. Smog formation is accelerated when nitrogen oxides (NOx) react with volatile organic compounds that are released from the incomplete combustion of fossil fuels at high ambient temperatures (18). Akbari et al. calculated that daytime temperature reductions would decrease reliance on air conditioning and reduci: emissions of NOX (nitrous oxides) from coal fired electricity plants for an estimated $10 \%$ reduction in smog precursors or a reduction of 350 tons of NOx per day (4). Los Angeles has a smog offset trading mark that trades NOx at 3,000\$ per ton. To convert this to $\mathrm{c} / \mathrm{kWh}$ of peak power, the researchers multiplied by $0.5 \mathrm{~kg} / \mathrm{MWH}$ to get $.15 \mathrm{c} / \mathrm{kWh}$. Hence, the 350 tons/day of avoided "equivalent" NOx is then worth about one million US dollars per day to a city like Los Angeles (4).

Other researchers reported that air pollution levels are reduced when wind blown particulates ( $P M_{2.5}$ and $\left.P M_{10}\right)$ stick to the leaves and stems of plants. Similarly, gaseous air pollutants can be dissolved or sequestered, particularly carbon dioxide, through stomata on plant leaves $(64,65,76,77,78)$. Johnson et al. estimated that 2,000 square meters of un-mowed grass on a roof could remove as much as $4,000 \mathrm{~kg}$ of particulates in their leaves and stems (43). Peck cites German research (un-translated) and suggests that one square meter of uncut grass on a roof would create enough oxygen to meet the needs of one human over one year (67). More recently, Tan and Sia sampled roof temperatures, roof glare and other air quality parameters both pre- and post-green roof installation in Singapore (105). They used light sensors, mini-volume aerosol samplers, particle counters, an aethalometer for black carbon mass concentration and an НOBO weather station to report that acidic gaseous pollutants, glare, ambient green roof 
surface temperatures and black carbon mass (or soot) levels all dropped significantly after the installation of the green roof. This research supports the notion that further use of urban vegetation in any form would be a benefit to urban air quality (105).

\section{Conclusion}

Given this significant and growing body of global green roof literature, it seems obvious that green roofs contribute positively to a myriad of complex environmental problems associated with densely populated urban areas. Benefits include the reduction of ambient urban surface temperatures or urban heat island reduction, reduction in heat flux into buildings, improvements to stormwater runoff quantity and quality, protection of roof membranes, habitat restoration with species conservation and reduced building energy demand in low rise or commercial buildings, particularly in the summer months. Nonetheless, more specific research is required to support the potential benefits of green roofs and their role in mitigating urban air pollution.

Currently, it is hypothesized that adding urban vegetation, particularly green roofs, will reduce the level of gaseous pollutants measured in urban air. By extension improved air quality would eventually provide a benefit to human health and potentially save lives. Ultimately, adding vegetation to urban surfaces might reduce the public health costs associated with increased doctor's visits, hospitalizations and pharmaceuticals that result from poor air quality in urban areas $(118,57,83,84)$.

The following research will address the current jap in research on quantifying the effect of green roofs on urban air quality. The study will investigate the effect of adding different types of roof top vegetation through a variety of scenarios in a study area located in Midtown Toronto, Ontario, Canada. It is beyond the scope of this investigation to quantify the effects of improved air quality on human health outcomes and the economics of health care. 


\section{Chapter 4: Method}

\section{Study Method}

It is well known that trees, shrubs and other natural vegetation affect urban air contaminant levels, and, by extension, air quality and the overall experience of health and well-being of humans living in urban areas $(2,6,7,16,17)$. Quantifying the contribution of green roofs in reducing air contaminant levels within an urban neighbourhood, however, is a relatively new application within the emerging discipline of green roof study.

A geographic study area known as Midtown was selected within the Greater City of Toronto. Midtown is constituted by parts of Ward, 22 (St. Pauls), Ward 27 (Toronto central-Rosedale) and Ward 20 (Trinity Spadina) and bounded by Spadina Avenue in the west, Bloor Street in the south, Eglinton Avenue in the north and the Don Valley ravine, Bayview Avenue, Moore Street, Frobisher Street and Chaplin Street in the east.

In order to complete this study, previous research by Kenny on the economic and environmental profile played the urban forest in Midtown was scrutinized (44). Kenny quantified the urban forest characteristics that could be estimated by the four main modules (A, B, C, and D) within the UFORE (Urban Forest Effects) Model. In consultation with the UFORE modellers in Syracuse, New York, Kenney collected data from 72 randomly selected on-the-ground study plots within the Midtown neighbourhood as per the UFORE field collection tool (77). Kenny's report provided a profile or urban forest health and a subsequent analysis that forestry managers in the City of Toronto still use today (44).

This researcher obtained permission from Kenny to utilize the original criterion plot data from the 72 randomly selected plots in Midtown. Using UFORE - D. The researcher was able to manipulate specific data elements and develop scenarios to investigate the effect of urban vegetation, particularly green roofs on air contaminants levels in Midtown. The researcher visited the 72 randomly 


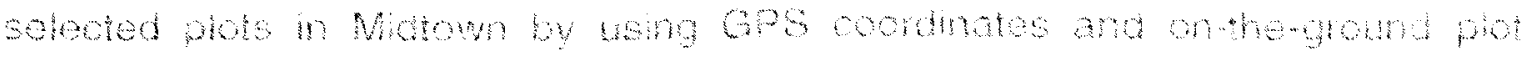

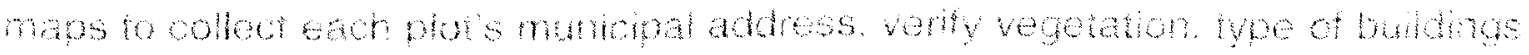
and other plot ratures that vere demedrelevat wo the study.

\section{Figure 10: Toronto Wards}

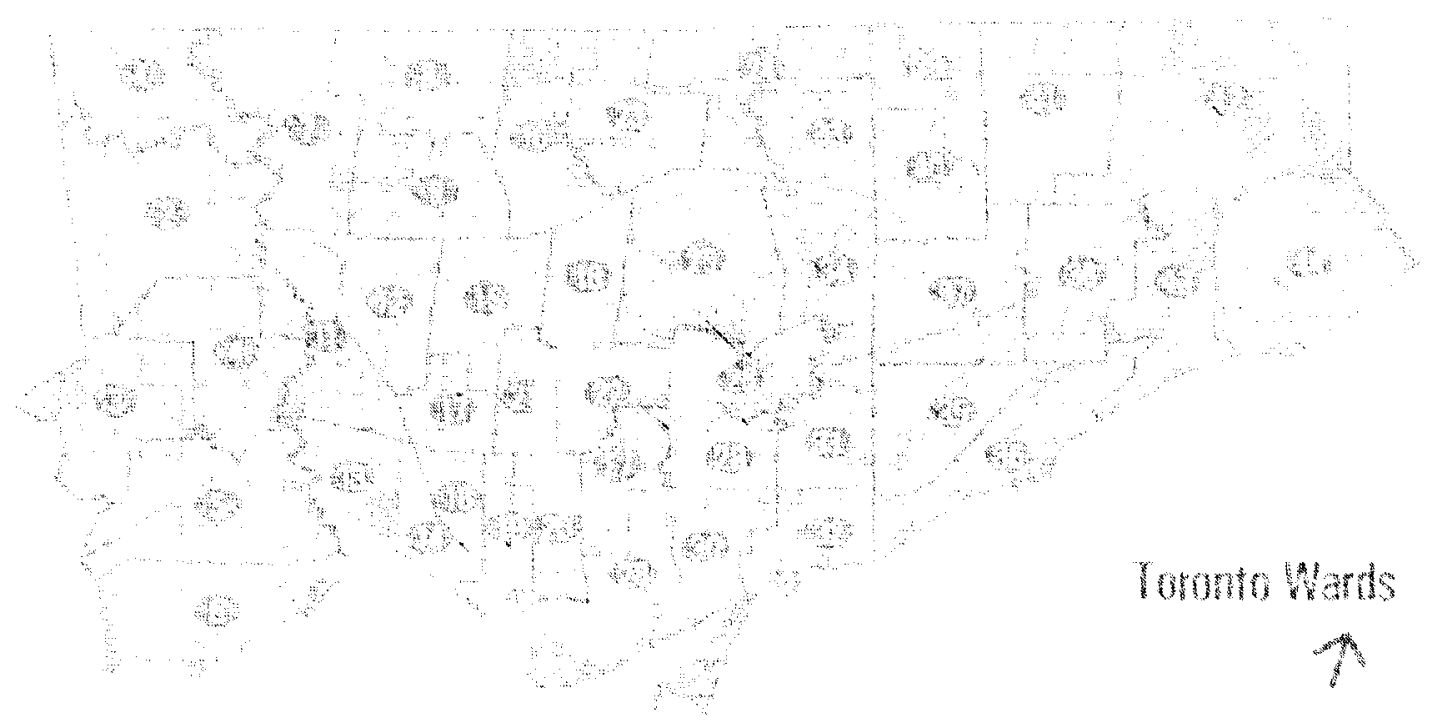

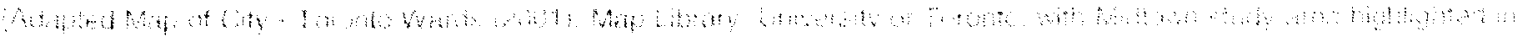

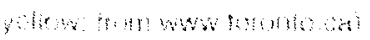

Each sample plot was croular with a radius of $1+287$ meters and provided a total suntace area of $400 \mathrm{~m}^{2}$ or 0.94 ha per plot. The tota sampled area was 28,800 m" or 288 ha with Midtown. The totel area of the Midown netghboumood was approximately $\{, 216$ ha within the City of Toronto. Plots were selected from land-use lypes by randomly selecting points from a $50 \mathrm{~m} \times 50 \mathrm{~m}$ gnd, overlaid on a GIS-based map of Midtown, using Aro View GIS 31. Colour onhophotos of the area were analyzed using Aro View as 3.1 to calculate plot detals as required. Each orthophoto was examined separately at a scale of approxmately 1 s000. Wimin each plot a forest suveyols lransit was utilized to detemme the soordinates of each Yeature within the plot relative 10 a GP-established plot onter (44). Using this method, the UTM (Unversal Transverse Merotor) comorinates of each plot center were known by the researcher. 
Fince 11: Sample Plot mintown
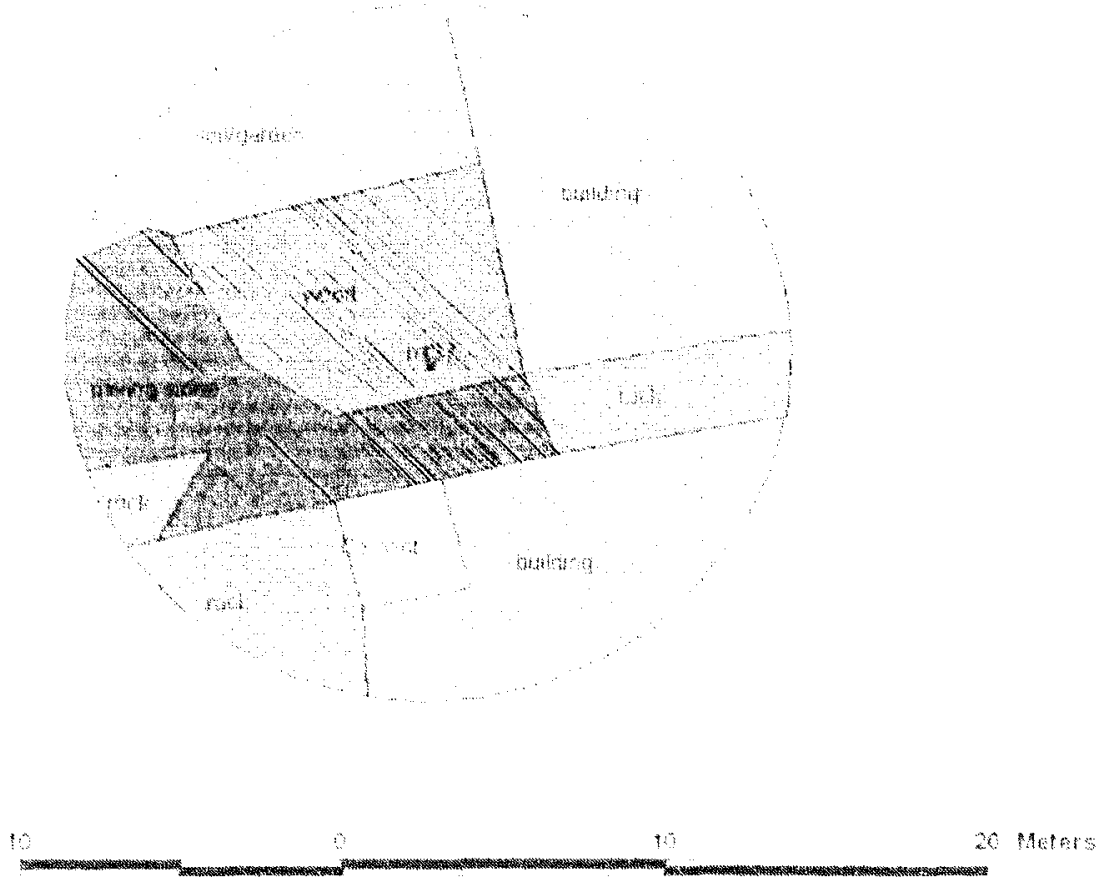

The Betwe to phot dasstiodion whin Motown was developed by Nowak and

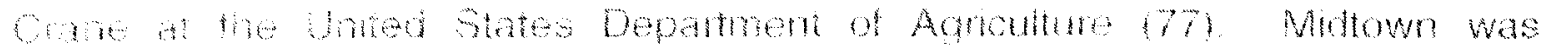
strated into ent knduse chases low medum and high residental:

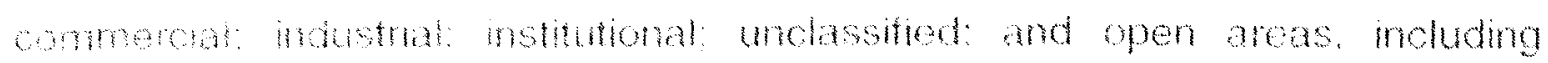
oske, rames cemeteries, iranspontaton comdons and golt courses. These

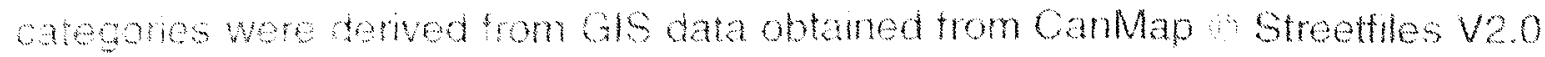
rom OMT Spmar $2000(44)$

\section{UFORE Computer Model}

The Unam Forest Etects (UFORE; computer modol was developed to help spowty magers and researchers quantify uban forest stucture function. and Winorativ sost masion based on standard inputs of field meteorological and polition tata. 
In this research, a UFORE-based field collection tool guided researchers on the collection and measurement of plot features such as buildings, amount of cement, tar, impervious material, soil, rock, duff/mulch, herbaceous, grass, wild grass, water, shrubs and other ground cover (44). Other plot features were recorded as point items including: trees; shrubs; telephone poles; light standards; traffic signs; sewer grates; fire hydrants and other above ground point utilities; or as polygons with each vertex recorded: shrub beds; grass; wild grass; soil; duff/mulch; herbaceous (excluding grass and shrubs); water; buildings; asphalt; cement; rock; wood; and other impervious material.

On each of the 72 plots, the following additional information was recorded:

- Land use

- Plot tree cover (\%)

- Ground cover (\%)

- Building information (wall material, roof material, building height in meters)

- Shrub information (species, height (meters), percent missing, and percent of coverage of the plot)

- Tree information including species, diameter at breast height (dbh) taken at 1.37 meters, total height, bole height - height to base of live crown, crown width, missing crown, health of tree and distance to buildings (44).

The UFORE D computer model also necessitated the collection manipulation of one year of local hourly meteorological data and air pollutant concentration measurements from the City of Toronto. Meteorological data and air pollutant concentration data from Toronto in 1998 was used for this study for several reasons. Firstly, it was 1998 Toronto data that was used in the Kenny study in 2001. The meteorological data had been collected for use by the UFORE model and then stored at the Northeastern Forest Research Station in Syracuse, New York. The 1998 meteorological data was easily accessed and utilized by this researcher. The UFORE modellers recommended that the researcher use this 1998 Environment Canada meteorological and pollutant data from Toronto as a 
significant amount of time had already been dedicated to its manipulation to fit the requirements of the UFORE model for the Kenny study (44). Nonetheless, the use of 1998 hourly meteorological data marks a limitation in the study. If possible, a profile of local hourly meteorological data and air pollutant concentrations from 2004 within the Midtown neighbourhood itseif would have produced a more accurate pollutant analysis for the current study.

There are several modules within the UFORE computer model that facilitate research. They include:

UFORE-A: Anatomy of the Urban Forest - quantifies urban forest structure (species composition, density, tree health, leaf area, leaf and tree biomass).

UFORE-B: Biogenic Volatile Organic Compound (VDC) emissions - quantifies hourly urban forest VOC emissions (isoprene, monoterpenes and other VOC emissions that contribute to ozone formation) and ozone and $\mathrm{CO}$ formation based on VOC emission.

UFORE-C: Carbon Storage and Sequestration - calculates total carbon (C) storage potential and gross and net $C$ sequestered annual by the urban forest based on field data.

UFORE-D: Dry Deposition of Air Pollution - quantifies the hourly amount of pollution removed by the urban vegetation and the associated per cent improvement in air quality through out a year. Pollution removal is calculated for $\mathrm{O}_{3}, \mathrm{SO}_{2}, \mathrm{NO}_{2}, \mathrm{CO}$ and $\mathrm{PM}_{10}(74,77,75,6)$.

\section{UFORE-D}

UFORE-D calculates the level of dry deposition of air pollution, (that is, the amount of pollution removed during non-precipitation periods) on urban 
vegetation. The module also estimates the hourly dry deposition of $\mathrm{O}_{3}, \mathrm{SO}_{2}$, $\mathrm{NO}_{2}, \mathrm{CO}$ and $\mathrm{PM}_{10}$ on urban vegetation throughout a year. UFORE calculations are based on vegetation cover data, hourly weather data and pollution concentration data. This hourly weather and pollution data were collected and collated from three Environment Canada weather stations: Toronto's Pearson International Airport; Buttonville Airport; Richmond Hill; and Toronto Island Airport in downtown Toronto. The researcher chose one year of hourly pollution data from Environment Canada data due to the logistics of converting hourly data to a UFORE-compatible format.

Figure 12: UFORE- $D$ and Plants

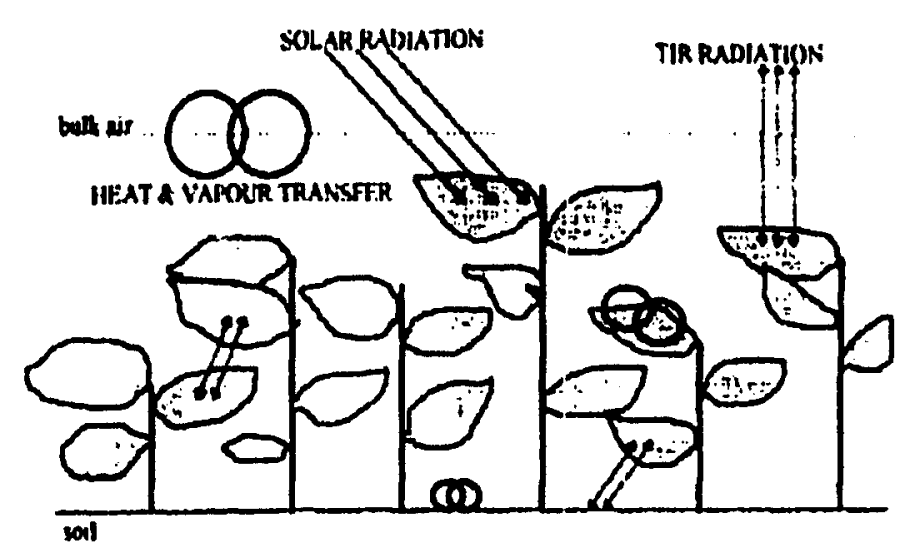

(Del Barrio (1998) (23) p. 184)

In this basic green roof schemata, note that several natural systems occur simultaneously between the atmosphere and the surrounding green roof canopy. Firstly, solar energy is delivered by the sun and this activates a plant's internal energy system. This heat energy drives many cellular processes like photosynthesis, evapo-transpiration and the opening and closing of stomata themselves. Leaf stomata act at doorways into internal plant structures and determine what air contaminants or particulates to accept or reject. Gaseous air contaminants flow down a diffusion gradient through the leaf stomata and into the internal plant structures. Heat energy can be transferred within and between the leaves and the soil on the ground below and the surrounding air via longwave 
radiation (shown as TIR radiation in figure 12). Evapo-transpiration also occurs within leafs via three phenomena: water evaporates inside the leaves via stomatal cavities; vapour diffuses up to the leaf surface; and convective vapour transport occurs from the leaves to the surrounding air as each leaf cell controls its own moisture levels within and outside their cellular environment and the surrounding atmosphere. Finally, there is an element of heat and vapour transfer to and from the soil layer beneath the plant canopy (23).

UFORE-D derives pollution outputs by using the hourly pollution input data from Environment Canada combined with predicted or default plant species measurements derived from known systems to estimate the amount of air contamination a particular leaf will absorb. Calculations are aggregated in order to predict pollution reductions over given vegetated surface areas. UFORE D utilizes daily hourly temperatures, humidity, barometric pressures, hourly pollutants, plant surface areas, and many other characteristics including height, species, general health, leaf area index, to determine calculations as explained below.

\section{Calculations in UFORE-D}

In UFORE-D the pollutant flux $\left(F ;\right.$ in $\mathrm{g} \mathrm{m}^{-2} \mathrm{~s}^{-1}$ ) is calculated as the product of deposition velocity $\left(V_{d}\right.$; in $\left.\mathrm{m} \mathrm{s}^{-1}\right)$ and the pollutant concentration $\left(C\right.$; in $\left.\mathrm{g} \mathrm{m}^{-3}\right)$ :

$$
F=V_{d}^{\star} C
$$

Deposition velocity is calculated as the inverse of the sum of the aerodynamic resistances $\left(R_{a}\right)+$ laminar boundary layer $\left(R_{b}\right)+$ canopy $\left(R_{c}\right)$ resistances:

$$
V_{d}=\left(R_{a}+R_{b}+R_{c}\right)^{-1}
$$

Hourly meteorological data were used in estimating $R_{a}$ and $R_{b}$. The aerodynamic resistance is calculated as (45): 


$$
R_{a}=u(z)^{*} u^{-2}
$$

where $u(z)$ is the mean windspeed at height $z\left(\mathrm{~m} \mathrm{~s}^{-1}\right)$ and $u$ - is the friction velocity $\left(\mathrm{m} \mathrm{s}^{-1}\right)$.

$$
U:=\left(k^{\star} u(z-d)\right)\left[\ln \left((z-d)^{\star} z_{0}^{-1}\right)-\Psi_{M}\left((z-d)^{\star} L^{-1}\right)+\Psi_{M}\left(z_{0}^{*} L^{-1}\right)\right]^{-1}
$$

where $\mathrm{k}=$ von Karman constant, $\mathrm{d}=$ displacement height $(\mathrm{m}), \mathrm{z}_{0}=$ roughness length (m), $\Psi_{M}=$ stability function for momentum, and $L=$ Monin-Obuhkov stability length. $L$ was estimated by classifying hourly local meteorological data into stability classes using Turner classes and then estimating $1 / L$ as a function of stability class and $z_{0}(70)$.

When $L<0$ (unstable):

$$
\Psi_{M}=2 \ln [0.5(1+X)]+\ln \left[0.5\left(1+X^{2}\right)\right]-2 \tan ^{-1}(X)+0.5 \pi
$$

where $X=\left(1-28 z L^{-1}\right)^{0.25}(4)$.

When $L>0$ (stable conditions):

$$
u \cdot=C_{D N} u^{\star}\left\{0.5+0.5\left[1-\left(2 u_{O} /\left(C_{D N}^{1 / 2 \star} u\right)\right)^{2}\right]^{1 / 2}\right\}
$$

where $C_{D N}=k\left(\ln \left(z / z_{0}\right)\right)^{-1} ; v_{0}^{2}=\left(4.7 z \diamond \theta_{*}\right) T^{-1} ; g=9.81 \mathrm{~m} \mathrm{~s}^{-2} ; \theta \cdot=0.09\left(1-0.5 N^{2}\right)$; $T=a i r$ temperature $\left(K^{\circ}\right)$; and $N=$ fraction of opaque cloud cover $(108,109)$. Under stable conditions, $v$. was calculated by scaling actual windspeed with a calculated minimum windspeed based on methods given in EPA (1995) (109).

The quasi-laminar boundary-layer resistance was estimated as (89):

$$
R_{b}=2(S c)^{2 / 3}(P r)^{-2 / 3}\left(k^{*} u_{*}\right)^{-1}
$$


where $k=$ von Karman constant, $\mathrm{Sc}=\mathrm{Schmidt}$ number, and $\mathrm{Pr}$ is the Prandtl numbor.

In-leaf, hourly tree canopy resistances for $\mathrm{O}_{3}, \mathrm{SO}_{2}$, and $\mathrm{NO}_{2}$ were calculated based on a modified hybrid of big-leaf and multilayer canopy deposition models. Canopy resistance $\left(R_{c}\right)$ has three components: stomatal resistance $\left(r_{s}\right)$, mesophyll resistance $\left(r_{m}\right)$, and cuticular resistance $\left(r_{t}\right)$, such that:

$$
1 / R_{c}=1 /\left(r_{s}+r_{m}\right)+1 / r_{t}
$$

Mesophyll resistance was set to zero $\mathrm{s} \mathrm{m}^{-1}$ for $\mathrm{SO}_{2}(20)$ and $10 \mathrm{~s} \mathrm{~m}^{-1}$ for $\mathrm{O}_{3}$ (41). Mesophyll resistance was set to $100 \mathrm{~s} \mathrm{~m}^{-1}$ for $\mathrm{NO}_{2}$ to account for the difference between transport of water and $\mathrm{NO}_{2}$ in the leaf interior, and to bring the computed deposition velocities in the range typically exhibited for $\mathrm{NO}_{2}$ (52). Base cuticular resistances were set at $8,000 \mathrm{~s} \mathrm{~m}^{-1}$ for $\mathrm{SO}_{2}, 10,000 \mathrm{~s} \mathrm{~m}^{-1}$ for $\mathrm{O}_{3}$, and $20,000 \mathrm{~s} \mathrm{~m}^{-1}$ for $\mathrm{NO}_{2}$ to account for the typical variation in $\mathrm{r}_{\mathrm{t}}$ exhibited among the pollutants (52).

Hourly inputs used to calculate canopy resistance are photosynthetic active radiation (PAR; $\mu \mathrm{E} \mathrm{m}^{-2} \mathrm{~s}^{-1}$ ), air temperature $\left(T_{\mathrm{a}}\right)$, windspeed $\left(\mathrm{s} \mathrm{m}^{-1}\right), u\left(\mathrm{~s} \mathrm{~m}^{-1}\right)$, CO2 concentration (set to $360 \mathrm{ppm}$ ), and absolute humidity $\left(\mathrm{kg} \mathrm{m}^{-3}\right)$. Air temperature, windspeed, $u$, and absolute humidity are measured directly or calculated from measured hourly meteorological data. Total solar radiation is calculated based on the METSTAT model with inputs from the meteorological data set (63). PAR is calculated as 46 percent of total solar radiation input (68, 69).

As $\mathrm{CO}$ and removal of particulate matter by vegetation are not directly related to transpiration, $A_{c}$ for $C O$ was set to a constant for in-leaf season $\left(50,000 \mathrm{~s} \mathrm{~m}^{-1}\right)$ and leaf-off season $\left(1,000,000 \mathrm{sm}^{-1}\right)$ based on data from (12). For particles, the 
median deposition velocity from the literature (8) was $0.0128 \mathrm{~m} \mathrm{~s}^{-1}$ for the in-leaf season. Base particle $V_{d}$ was set to 0.064 based on a LAl of 3 and a 50-percent re-suspension rate of particles back to the atmosphere (122). The base $V_{d}$ is adjusted according to actual LAI and in-leaf versus leaf-off season parameters.

\section{Pollution Deposition}

Particle collection and gaseous deposition on deciduous trees in winter assumed

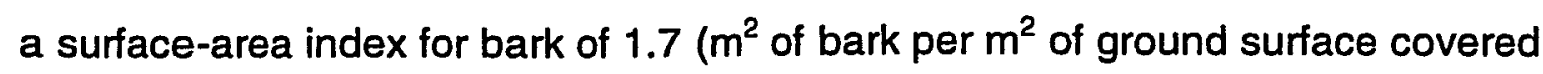
by the tree crown) (74). To limit deposition estimates to periods of dry deposition, deposition velocities were set to zero during periods of precipitation.

Hourly pollution concentrations (ppm) for gaseous jollutants in Toronto were obtained from the Ministry of the Environment (6 monitors at 3 sites). Hourly $\mathrm{ppm}$ values were converted to $\mu \mathrm{g} \mathrm{m}^{-3}$ based on measured atmospheric temperature and pressure. Average daily concentrations of $\mathrm{PM}_{10}\left(\mu \mathrm{g} \mathrm{m}^{-3}\right)$ were also obtained from the Ministry of the Environment (6 monitors at 3 sites). Missing hourly meteorological or pollution-concentration data were estimated using the monthly averages for that specific hour.

Average hourly pollutant flux ( $\mathrm{g} \mathrm{m}^{-2}$ of canopy coverage) among the pollutant monitoring sites was multiplied by Midtown's grass coverage $\left(\mathrm{m}^{2}\right)$ to estimate total hourly pollutant removal across Midtown. Bounds of total removal of $\mathrm{O}_{3}$, $\mathrm{NO}_{2}, \mathrm{SO}_{2}$, and $\mathrm{PM}_{10}$ were estimated using the typical range of published tree and shrub in-leaf dry deposition velocities (52).

To approximate boundary-layer heights in the study area, mixing-height measurements were used. Daily morning and afternoon mixing heights were interpolated to produce hourly values using the EPA's PCRAMMIT program (108). Minimum boundary layer heights were set to $150 \mathrm{~m}$ during the night and $250 \mathrm{~m}$ during the day based on estimated minimum boundary layer heights in cities. Hourly mixing heights $(m)$ were used in conjunction with pollution 
concentrations $\left(\mu \mathrm{g} \mathrm{m}^{-3}\right)$ to calculate the amount of pollution within the mixing layer $\left(\mu \mathrm{g} \mathrm{m}^{-2}\right)$. This extrapolation from ground-layer concentration to total pollution within the boundary layer assumes a well-mixed boundary layer, which is common in daytime (unstable conditions) (15). The amount of pollution in the air was contrasted with the amount removed by the vegetation on an hourly basis to calculate the relative effect of vegetation in reducing local pollution concentrations as shown by:

$$
E=R(R+A)^{-1}
$$

where $E=$ relative reduction effect $(\%) ; R=$ amount removed by vegetation $(\mathrm{kg})$; $A=$ amount of pollution in the atmosphere $(\mathrm{kg})$.

The ability of individual vegetation (trees, shrubs and grass) to remove pollutants was estimated for each diameter class using the formula (79):

$$
\mathrm{IX}=\mathrm{R}_{\mathrm{t}}(\mathrm{LAx} / \mathrm{Lat}) / \mathrm{Nx}
$$

where I $x=$ pollution removal by individual units e.g. trees in diameter class $x$ $\left(\mathrm{kg} /\right.$ tree); $R_{t}=$ total pollution removed for all diameter classes $(\mathrm{kg}) ; \mathrm{LAl}=$ total leaf area in diameter class $x(\mathrm{~m} 2)$; LAI $=$ total leaf area of all diameter classes $\left(\mathrm{m}^{2}\right)$; and $N x=$ number of trees in diameter class $x$. This formula yields an estimate of pollution removal by individual trees, shrubs and grass based on leaf surface area (the major surface for pollutant removal).

\section{Scenario Development}

The researchers created seven scenarios that represented simulations of natural vegetation levels within the Midtown Toronto study area. These varying amounts of natural vegetation were created by manipulating the number of trees, shrubs and grass species within the 72 study plots in Midtown. UFORE-D was used to quantify the impact of varying urban vegetation on air pollutant levels. Air 
pollutant levels affected by vegetation that can be simulated by UFORE-D include: carbon dioxide, sulphur dioxide, nitrous oxide, ozone, and carbon monoxide as well as particulate levels for example, dust and lead.

\section{Scenario 1}

BASELINE: this scenario was based on the reductions in pollutants provided by existing trees and shrubs in Midtown.

\section{Scenario 2}

Green Walls: this scenario examined the effest on air pollutant reductions in Midtown when existing trees and shrubs were removed and vertical "hedges" or walls of Juniper ${ }^{2}$ species were added within 3 meters of residential (medium and low) houses.

\section{Scenario 3}

No Big Trees: this scenario examined the effect on air pollutant reductions in Midtown when all big trees with a diameter-at-breast-height $>22 \mathrm{~cm}$ were removed.

\section{Scenario 4}

No Trees: this scenario examined the effect on air pollutant reduction in Midtown when all trees were removed and only shrubs remained. In some data runs, shrubs were replaced on flat roofs ie. commercial, institutional and high residential in Midtown.

\section{Scenario 5}

Trees off Buildings: this scenario examined the effect on air pollutant reduction in Midtown when trees that provided shade to buildings (within 3-5 meters) were removed.

\footnotetext{
${ }^{2}$ Walls of Juniper trees were chosen to represent a green wall, as UFORE is able to estimate the impacts of this green wall on energy consumption, which was utilized in a parallel study. Although vines can be selected for green walls, UFORE does not simulate the impacts of vines on energy consumption. Vines would not have a significantly different impact on air quality as their LAI is similar to that of the Juniper species selected for the green walls.
} 


\section{Scenario 6}

Trees Low Residential: this scenario examined the effect on air pollution in Midtown when baseline trees and shrubs were augmented with an extensive green roof or grass application on commercial, industrial, high residential and institutional buildings. The surface area available for this grass or green roof application represented approximately $9 \%$ of surface area within the 72 sample plots and was derived by summing the total building surface areas in each plot with a predicted flat roof. For purposes of this research, it was assumed that these roofs would be structurally sound for a green roof application.

\section{Scenario 7}

Grass Roofs: this scenario examined the effect on air pollution in Midtown when baseline trees and shrubs were augmented with an extensive green roof or grass application on all available buildings in Midtown. Hence roof surface areas were calculated by summing all building surface areas in the 72 plots including, commercial, industrial, institutional, low, medium and high residential buildings. The surface area consumed by buildings was approximately $20 \%$ of the total plot surface area available in Midtown. This was approximately double the surface area available for green roofs compared to scenario 6 . For purposes of this research, it was assumed that these roofs would be structurally sound for a green roof application.

Data obtained from the manipulations of these aforementioned scenarios will be discussed in the results section of the report.

\section{Limitations of UFORE Model}

For the grass roofs scenario, the $V_{d}$ was adjusted based on a predicted LAI of 3 for grasses (79). The model is programmed for individual species of tree and shrub LAl data as well as the predicted percent tree and shrub leaf areas calculated from UFORE-A data. Local leaf-on and leaf-off dates are given to the model so that deciduous-tree transpiration and related pollution deposition are 
limited to the in-leaf period; seasonal variation in removal can be illustrated for each pollutant. As the main interest in this study was a grass-only scenario, UFORE was set to a local leaf-on deciduous tree-transpiration rate for the Canadian in-leaf period. The leaf-on and leaf-off dates were adjusted to represent Canadian deciduous-tree transpiration and related pollution deposition in the in-leaf period. This represents the main experimental portion of the study, and hence a limitation. The UFORE model is biased toward scientific default values for all tree and shrub species values that are available in the model.

As mentioned previously, the study would have been more accurate had local Environment Canada meteorological and air contaminant data been collected at a weather station within the Midtown study area. Instead, Environment Canada data from 1998 was used to provide air pollution estimations in the study.

Another limitation was that the dollar values associated with the removal of pollutants over the year were provided by an externality process not well explained to the researcher. The monetary values were based on American externality values that were derived from work done by Murray (1994) in New York State's energy department. These values incorporate the perceived cost to society of pollution emissions based on predicted air pollution consequences to health and the environment. Although the relative dollar values are applicable to other regions, the exact values, even using Murray's assumptions, would most likely differ between countries with different government priorities for funding health care. There are other limitations including the UFORE model's inability to predict reduced building energy demand from green roofs. These limitations reduce the scope of using the UFORE to assess the overall benefits of green roofs, however, a fuller critique of the UFORE model is beyond the scope of this study. 


\section{Chapter 5: Results}

Results of the study are presented in figures $13-18$ below. Throughout figures 13-17, the histograms illustrate the UFORE model's estimates among scenarios and vegetation groupings concerning the amount of a particular air contaminant that was reduced. The air contaminants in the model here included: carbon monoxide, nitrogen dioxide, sulphur dioxide, ozone and particulate matter. In figure 18, the histogram reflects the amount of US $\$$ predicted to be associated with the overall reduction of the five major air contaminants measured by the UFORE model. The vegetation groupings were described in more detail in the method section above.

As might be predicted, the UFORE model illustrates that trees and shrubs remove air contaminants more effectively when compared to other vegetation groupings. Further, when trees are compared with shrubs, trees out-perform shrubs in their ability to reduce pollutants. This result is expected, based on the number of functioning leaf units that provide maximal surface area in contact with air and particulates. Despite the strong performance of trees and shrubs, it is neither practical nor plausible to seed most elevated roof surfaces with these heavy, tap and fibrous-rooted species.

The UFORE model illustrated that when grassy species were added to selected vegetation groupings, they too contributed to air contaminant reductions. Adding grass resulted in significant reductions across all five air contaminant levels measured by the UFORE model. Grass was chosen as a proxy unit for green roofs not only because it is are a known quantity in seed mixtures for green roof planting but also because the UFORE model was able to predict a leaf area index and evapo-transpiration rates in its calculation of air pollution values (Figures 13-17). 
Also of note throughout figures 14-17 are the results for scenarios with 'No Trees'. In figures 14-17, shrubs data were augmented by $9 \%$ in Midtown by adding equal surface area of shrubs to buildings with flat roofs -just as was done in scenario 6. Results indicate that a significant amount of air pollution is mitigated across contaminant groups when shrubs alone are at work in Midtown. This is a noteworthy finding in that shrubs are lighter, portable, are both evergreen and deciduous and can be placed among other appropriate plant groupings on extensive roofs in urban areas.

In figure 18 , the histogram illustrates a derived monetary value for each air contaminant removed by trees, shrubs and grass on roofs in the seven scenarios created by the researcher. These values were estimated using a median externality value for the United States based on calculations by Murray et al. (1994). The following values were set as default in the UFORE-D module and were based on dollars per metric ton $(t)$ :

$$
\mathrm{NO}_{2}=\$ 6,752 \mathrm{t}^{-1}, \mathrm{PM} 10=\$ 4,508 \mathrm{t}^{-1}, \mathrm{SO}_{2}=\$ 1,653 \mathrm{t}^{-1} \text {, and } \mathrm{CO}=\$ 959 \mathrm{t}^{-1} \text {. }
$$

Externality values for $\mathrm{O}_{3}$ were set to equal the value for $\mathrm{NO}_{2}=\$ 6,752 \mathrm{t}^{-1}$ (71).

These results illustrate that a significant amount of air contamination is contained by the natural systems contained in trees, shrubs and grass species on roofs. Air contaminant reductions that would accompany the addition placement and installation of vegetation in urban areas would help achieve Canadian Kyoto Protocol objectives, and serve to improve the quality of life and health of all citizens in urban communities. 
Figure 13: Total Co removal (Mg) by trees, shubs and grass in Midrown per Antum

Total Co removal (Mg) by trees, shrubs and grass in Midtow

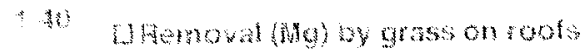

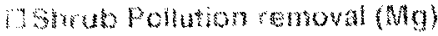

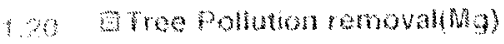

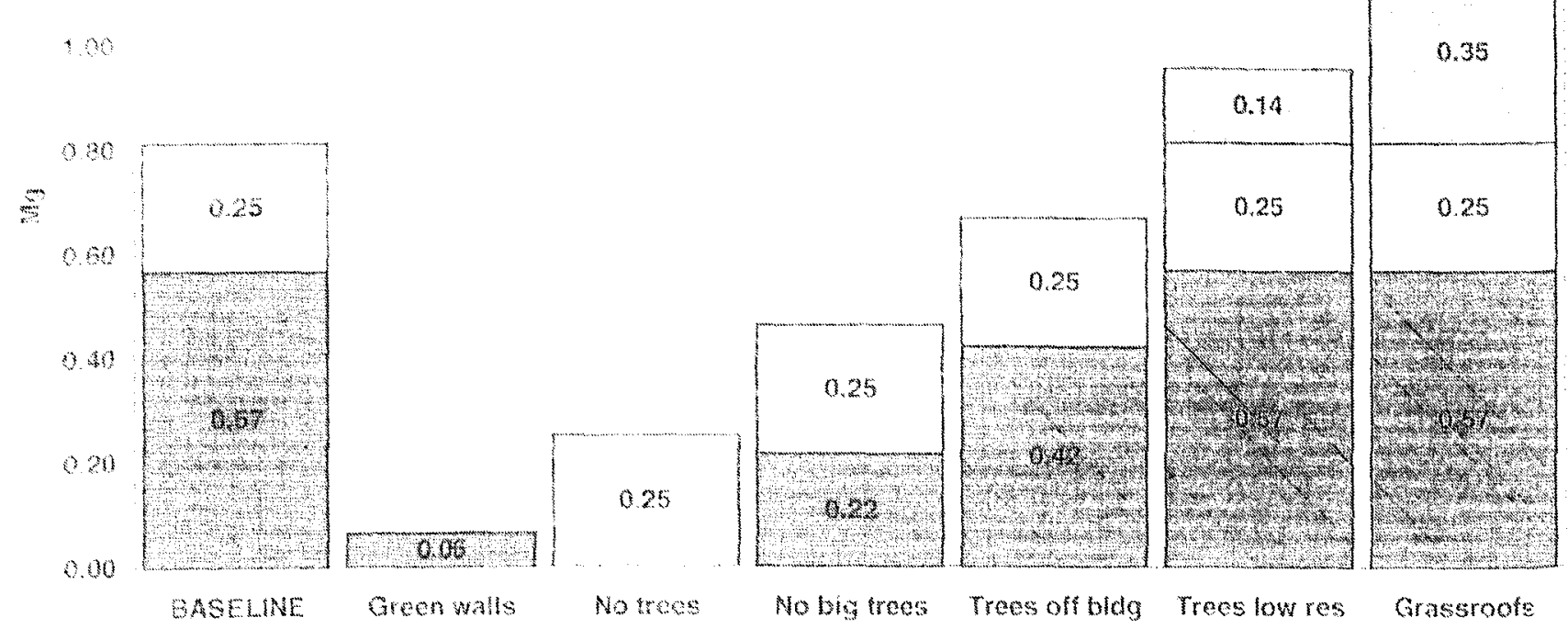


Figure 14: Total NO. removal (Mg) by trees. shrubs and grass in Midtown per Annum

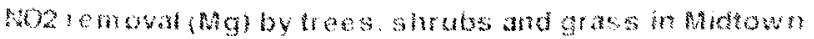

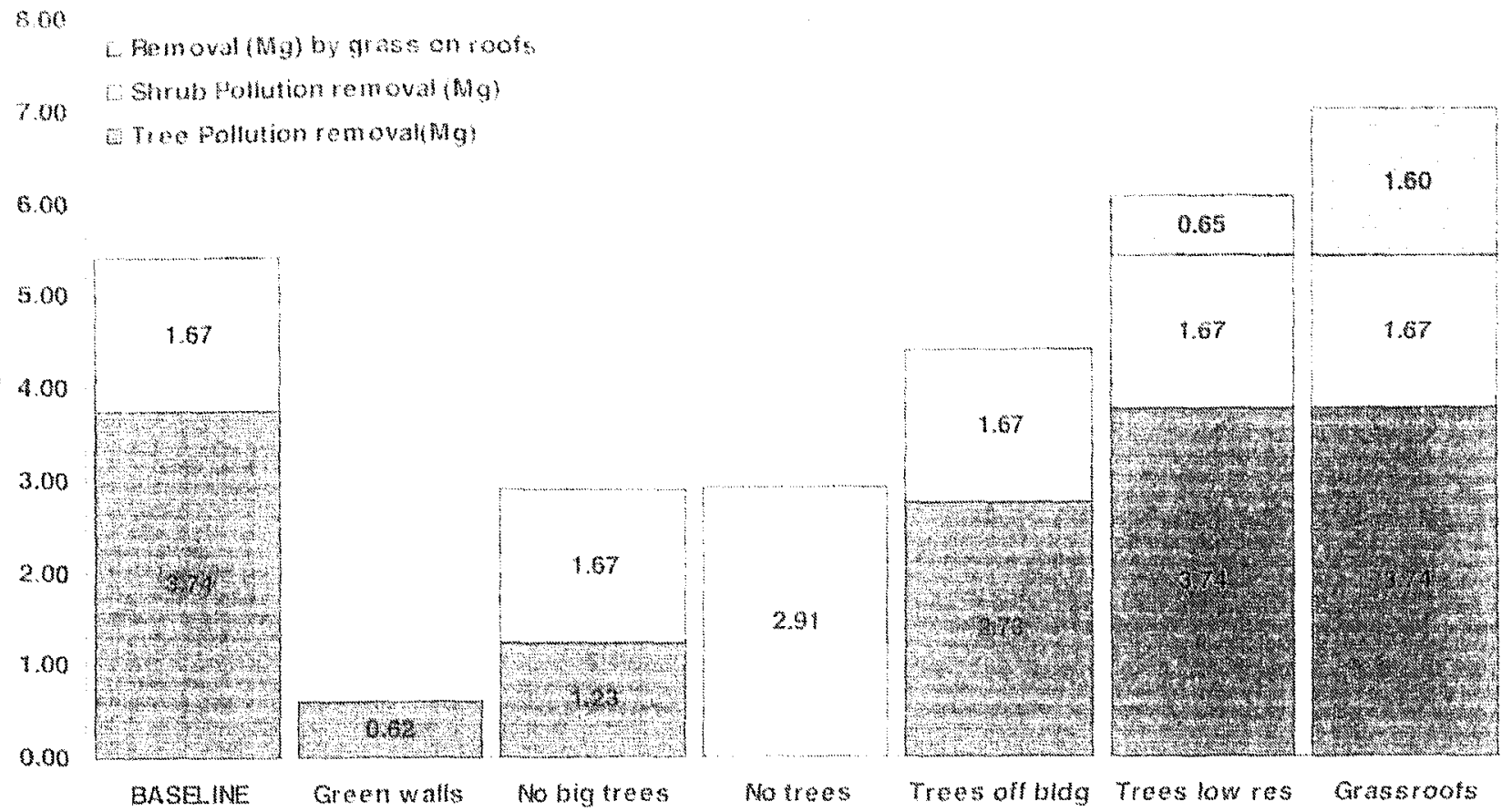


Figure 15: Total O removal (Mg) by trees, shrubs and grass in Midtown per Annum

\section{O removal (Mg) by lrees. shrubs and grass in Midtown}

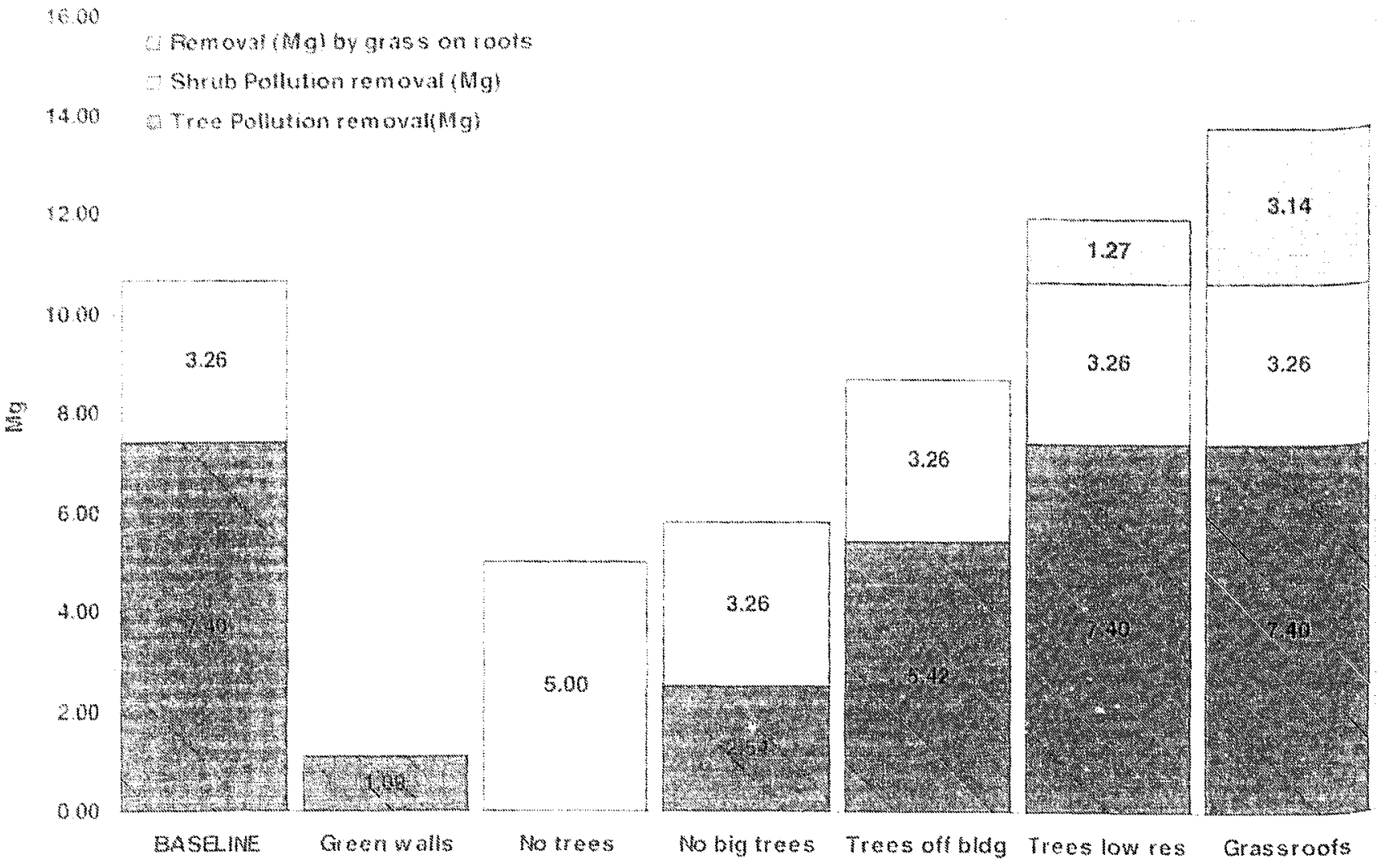


Figure 16: Total $\mathrm{PM}_{10}$ removal (Mg) by trees, shrubs and grass in Midtown per Annum

PM10 removal (Mg) by trees. ahrubs and grass in Midtown

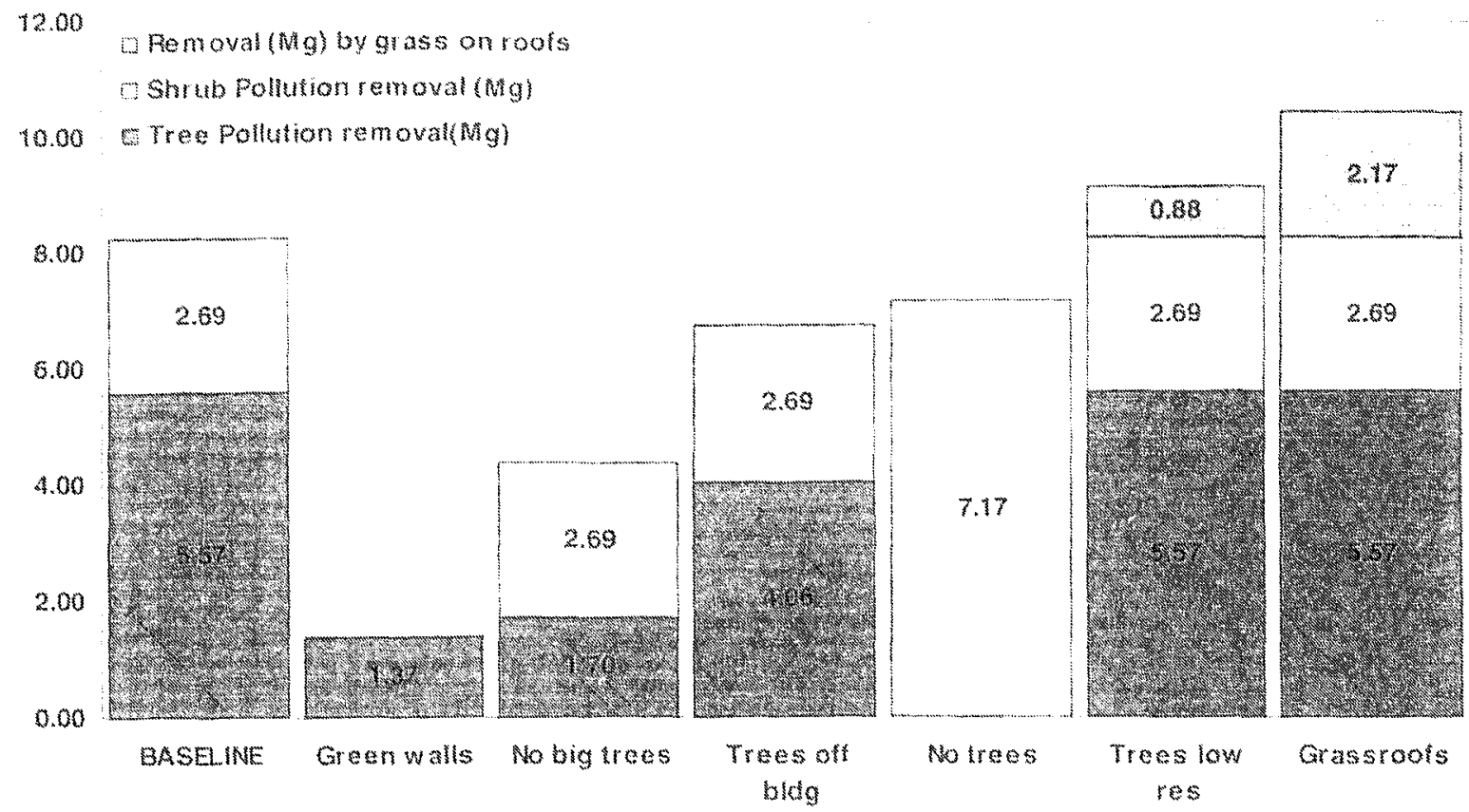


Figure 17: Total $\mathrm{SO}_{2}$ removal (Mg) by trees, shrubs and grass in Midtown per Annum

So2 removal (Hg) by trees. shubs and grass in Midtown

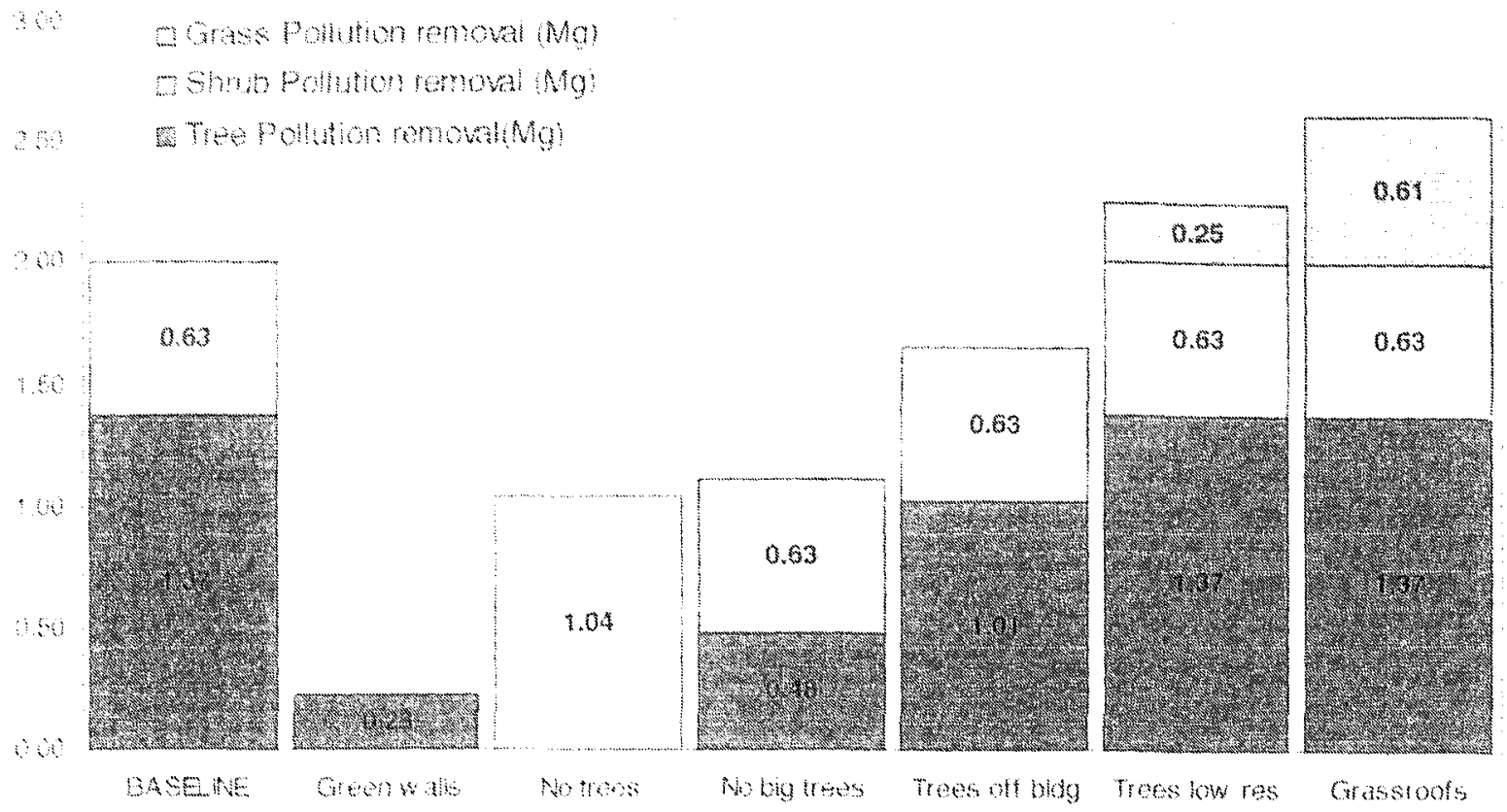


Figure 18: Total pollution removal value (US\$) by trees, shrubs and grass in Study Area per Annum

Total pollutant removal value (\$) by trees. shrubs and grass (rooftops) in Midtown.
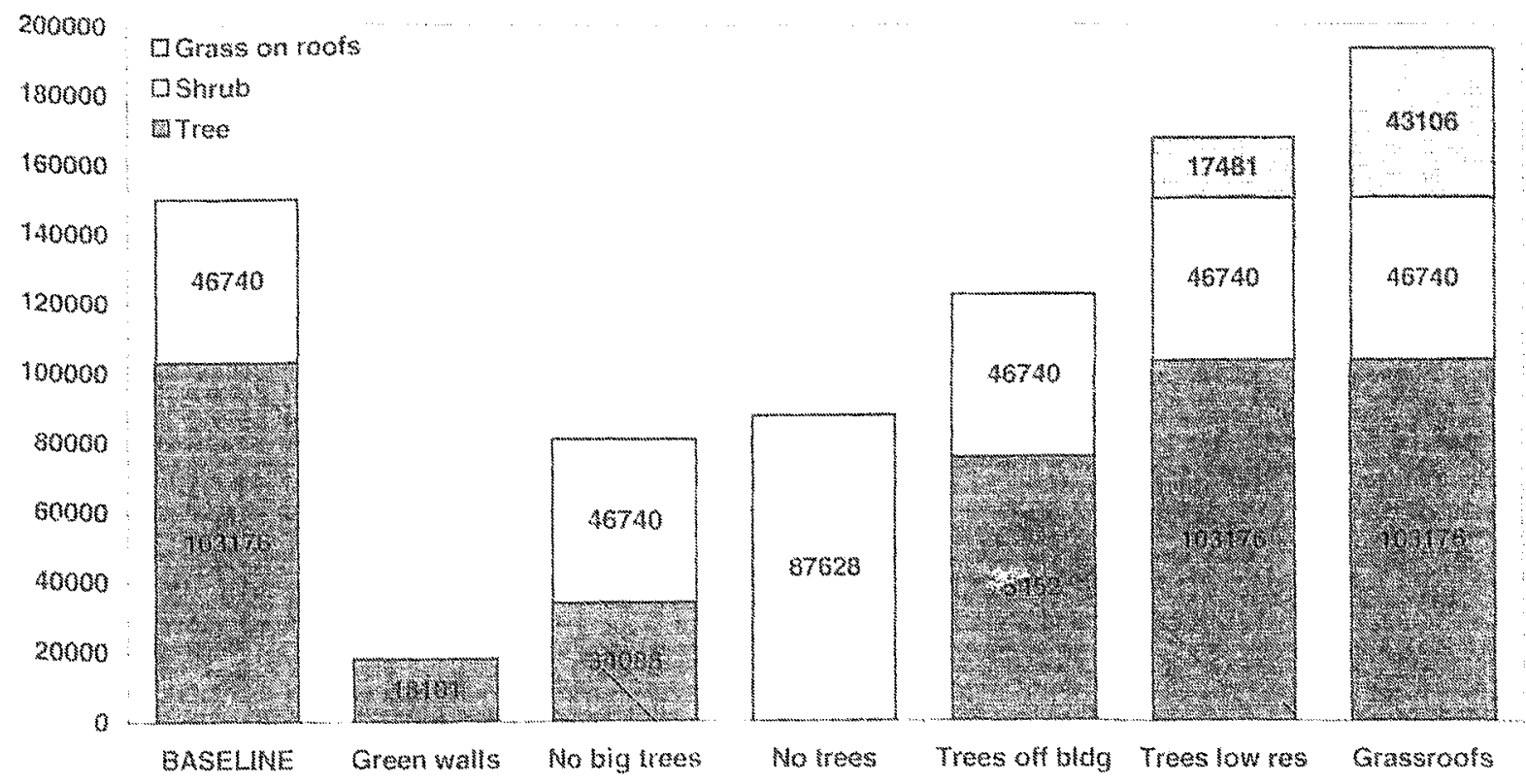
Figure 19: Proportional Removal Values for the Effect of Grass Poofs on Air Contaminants in Midtown per Annum

Proportional removal values for $\mathrm{CO}, \mathrm{NO}_{2}, \mathrm{O}_{3}, \mathrm{PM}_{10}$ and $\mathrm{SO}_{2}$ in Midtown with grass roofs.

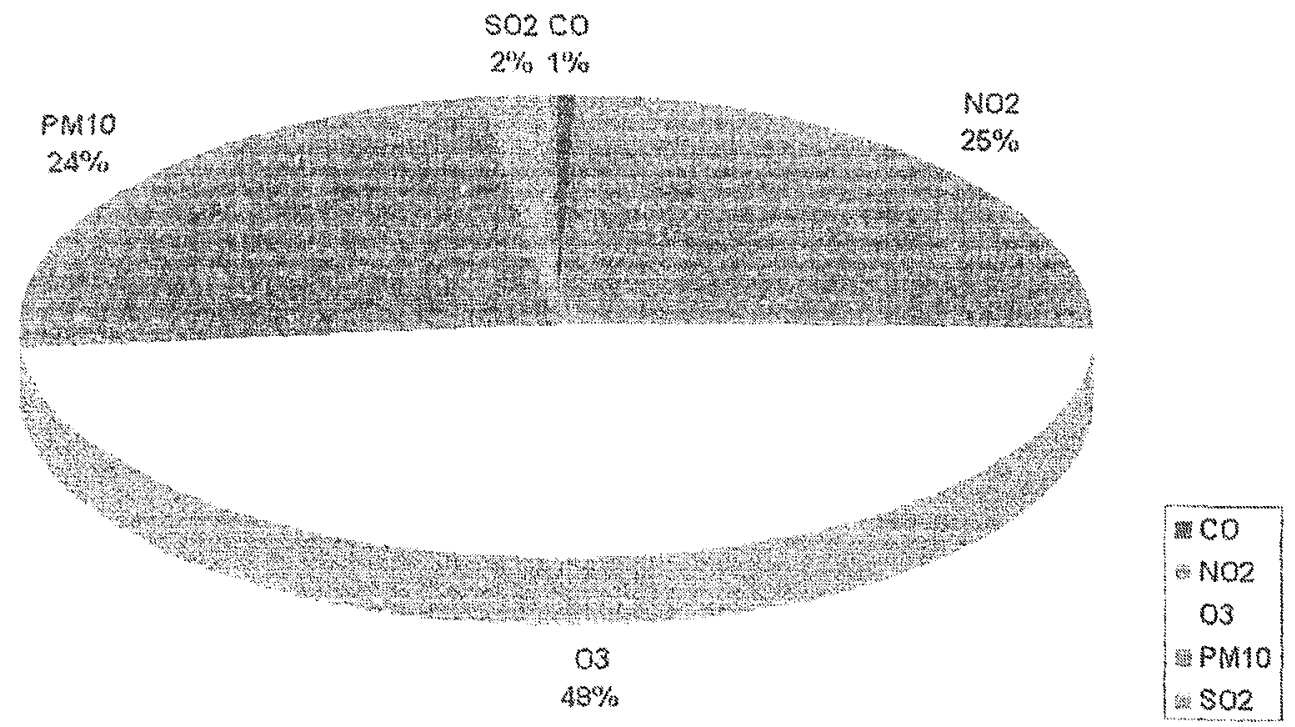




\section{Chapter 6: Discussion}

The results of this study clearly demonstrate that when roof surfaces are installed with green roofs or an application of grass on roofs there is a significant reduction in air contaminant levels over one year in Midtown. The UFORE model reports that across all 7 vegetation scenarios there are significant reductions in $\mathrm{CO}, \mathrm{NO}_{2}$, $\mathrm{SO}_{2}, \mathrm{PM}_{10}, \mathrm{CO}_{2}$ and ozone levels in Midtown over one year. Trees, however, clearly out perform shrubs and grass on roofs when comparing the amount of air contaminants reduced in Midtown over one year. This is not surprising given the large surface area provided by tree leaves compared with smaller shrubs and even smaller grass species. Shrubs however, were clearly a strong performer in the reduction of contaminants as well.

When grass was placed on every available building roof surface (approximately $20 \%$ of plot surface areas including low and mecium residential or sloped roofs) as shown in scenario 7 , air contaminant reductions were more than twice the amount of those in scenario 6 . In scenario 6, grass was applied to approximately $9 \%$ of plot surfaces as represented by flat roofs on commercial, industrial, institutional and high residential buildings. Scenario 6 presents a more realistic estimate of air contaminant reduction within a neighbourhood as green roof placement is better suited to flat roofs. Building owners and developers are more likely to install green roofs on buildings with flat roofs that are deemed structurally adequate to support the added weight of a green roof. As mentioned in the literature review, green roofs are best placed on flat roofs with a slope of less than $25 \%$; nonetheless, slopes up to this range have proven equally beneficial to the environment in European studies to date. As future building codes and green roof policies come to fruition in Toronto, and Canada, prescribed green roof design parameters including type of growing media, depth of media, choice of plant species and slope of roof will serve to maximize the environmental benefits prioritized within a particular jurisdiction. 
Of particular note in the results section is that the level of carbon monoxide removed by grass roofs exceeds the level of carbon monoxide removed by shrubs over one year in Midtown. Grass on every Midtown roof (scenario 7) removed $0.35 \mathrm{Mg}$ of $\mathrm{CO}$ per annum compared to $0.25 \mathrm{Mg}$ by existing shrubs. Further, the amount of $\mathrm{NO}_{2}$ removed by grass on roofs (scenario 7) at $1.60 \mathrm{Mg}$ per year was comparable to levels reduced by shrubs at $1.67 \mathrm{Mg}$ per annum. For ozone and $\mathrm{PM}_{10}$ grass on every roof (scenario 7) performed comparably well at $3.14 \mathrm{Mg}$ of ozone and 3.26 Mg for shrubs over one year in Midtown. Similarly for $\mathrm{PM}_{10}$, while grass of roofs proved 2.17 Mg per annum, shrub provided 2.69 $\mathrm{Mg}$ of reduction in one year in Midtown.

These results suggest that shrubs on roofs may be another option for urban planners and designers who are working to shape urban policy to mitigate air pollution with green roofs. In the case of $\mathrm{PM}_{10}$, reduction, study results report that shrubs performed better than trees and grass on roofs. Shrubs, particularly evergreen species, are physiologically active all year and as such, expose more leaf surface area to gaseous air contaminants for longer periods of time compared to deciduous shrub varieties that drop their leaves in winter months. Shrubs are also lighter than trees and less invasive in their root system therefore another strong plant choice for future green roof applications in urban areas that are concerned about reducing particulate matter.

The study results also support previous studies where urban trees out-perform other forms of urban vegetation in air contaminant reduction (44). While this may be true, this researcher would suggest that green roofs with shrubs may be a better choice for urban planners and designers than urban trees in some cases. Urban trees offer many benefits when provided with dedicated space for growth and maturity, such as in parks, on recreational lands or riversides. However, urban trees in dense downtown locations are more difficult for municipalities to manage and maintain compared to installing grass or shrubs on roofs. Trees need to be carefully sited and maintained in densely populated and polluted 
urban areas where grade level space is often co-opted by developers for built form. Similarly, almost $40 \%$ of newly planted urban trees succumb to heat stress, drought, air pollution or mechanical trauma in their first year (44). Also, urban trees need to be carefully permitted by municipalities so they do not interfere with overhead wires, below-ground infrastructure or the general safety of people walking on streets. Finally, trees, while aesthetically valued, take several dozen years before reaching their pinnacle in terms of air pollution mitigation. Nonetheless, as shown in the UFORE model, mature trees, compared to shrubs or grasses, possess a robust total leaf area index, and hence, expose more working leaf cells to gaseous contaminants and mitigate air pollution more profoundly than other plant species.

According to the OMA, ozone and particulate matter are two contaminants that are proven to negatively impact human health and increase costs to health care. Ozone and particulates impact humans differently depending on their age, preexisting illness and their geography throughout Ontario. It seems that a choice to live and work in some urban areas (e.g. Toronto) for some at-risk persons is choosing to exacerbate existing health conditions due to air pollution. In the year 2000 , the OMA reported that 33 million dollars worth of Ontario taxpayer's health care expenses was dedicated to treating air pollution-related phenomena (83, 84). The OMA predicts economic costs associated with air pollution using a sophisticated model called ICAP. The OMA reports that human health outcomes and the economic burdens to society associated with toxic air pollution will further deteriorate over the next decade as the population expands in concert with an insatiable reliance on burning fossil fuels for transportation, industry, heating and cooling. These predictions merge with a seeming general reluctance on the part of Provincial and Federal governments to be aggressive with strategies to reduce Ontario's air pollution and create a dismal picture of Toronto's air quality by 2015 $(83,84)$. 
In dense urban areas where competition exists between built form and green space, pre-planned, zoned or municipally designated areas for green elements could be represented by green roofs (shrubs and grass) on elevated surfaces. Strategic use of these green roofs could be used by urban planners and designers to help meet a city's Kyoto expectations or a Provincial air quality strategy such as the Anti-Smog Action Plan in Ontario.

\section{Application of the Study}

Applications for urban green roofs are shaped by building type, load restrictions, structural capacity of the roof, age of building, municipal policies, incentives, education and awareness of building professionals, architects and roofing specialists as well as the budget and long term vision of the community of building owners in urban areas. Green roofs can be designed, positioned or aggregated to enhance certain environmental benefits as prioritized by any one particular municipality or jurisdiction. Toronto, for example, may wish to consider aggregating green roofs in certain downtown neighbourhoods in order to protect rivers and river habitats in designated sewer sheds known for their combined sewer overflows. Similarly, a municipality like Toronto may wish to prioritize green roofs within existing strategies to improve air quality, reduce urban heat island effects or enhance stormwater runoff quantity and quality, given the unsatisfactory number of beach closures and air quality advisories that are sustained in any one year. Environmental benefits from green roofs can be prioritized by policy makers and shape the amount of roof surface area devoted to greening processes in any one geographic area. Similarly, a desired environmental outcome will guide the design recommendations for a green roof by informing the depth of planting medium as well as the plant species selected for a green roof. Certain benefits such as stormwater control and building energy conservation are maximized when substrate depths exceed or are equal to 15 $\mathrm{cm}$ of growing medium compared with $7-10 \mathrm{cms}$. 
Other environmental benefits such as air pollution mitigation and urban heat island reduction are predicted to be better served by aggregations or geographic clusters of green roofs within certain neighbourhoods. Previous studies report that ambient air temperature reductions and air quality improvements are more significant over aggregations compared with that of an individual green roof on a single building. As shown by the UFORE model in scenario 6 and 7 , aggregations of green roofs clustered within the 1,216 ha Midtown neighbourhood derived significant air quality benefits from green roofs. The amalgamated City of Toronto is approximately 63,203 ha where a predicted and significant range of roof surfaces are appropriate for green roof applications (6). Using approximations one could hypothesize that targeted aggregations of green roofs would significantly improve air quality in jurisdictions with a similar size and geography at Midtown. The City of Toronto might experience significant and unprecedented reductions in ozone and particulate matter by modifying existing planning tools to include the use of green roofs on new or retrofit building projects.

'Up front' costs associated with installing green roofs may be overlooked by a developer or building owner who is eligible for public or private incentives such as density bonuses, tax savings, or energy related subsidies for green roof applications. Green roofs on condominiums for example, provide much needed access to recreational space and can act as a marketing tool for property managers to entice and retain tenants in the long term. Insurance premiums and perimeter fencing costs associated with meeting the Ontario Building Code requirements may be prohibitive to the creation of accessible (intensive) green roofs compared to inaccessible (extensive) green roofs. Nevertheless, green roof design elements can vary among green roof projects and neighb. urhood buildings to influence specific or targeted environmental benefits derived from this simple and natural green technology. 


\section{Summary}

The results of this green roof study are applicable to a wide range of professionals who contribute to the creation of viable and sustainable urban communities including; urban and regional planners, watershed managers, atmospheric scientists, grass roots community leaders, parks and recreation departments, architects, landscape designers as well as urban foresters and landscape management practitioners. It is hoped that this report will spur further investigation on the effect of green roofs on air quality in other municipalities and Canadian jurisdictions as well provide support for the implementation of green roof policies that stimulate green roof installation in targeted or at-risk urban neighbourhoods. A commitment to ongoing primary green roof research will contribute to a body of slowly growing North American literature and will foster comparative studies between municipalities where different roofing membrane technologies, monitoring equipment, clusters or aggregations of green roofs, planting media and plant species have been employed. A Canadian emphasis on green roof research will contribute to the primary research required to support green roof policy development and implementation in Canadian jurisdictions particularly those with green roof research facilities.

UFORE-D reported that grass on roofs in scenarios 6 and 7 could reduce urban air contaminants such as $\mathrm{CO}, \mathrm{NO}_{2}, \mathrm{SO}_{2}, \mathrm{PM}_{10}, \mathrm{CO}_{2}$ and ozone levels contaminants with known deleterious health effects on human populations. Moreover, scenarios 6 and 7 were reportedly additive for air quality improvements compared with existing trees and shrubs at grade level in the urban Midtown study area. This researcher would support green roof technology as a practical and realistic planning tool for urban renewal where improvements in local air quality, ambient daytime temperatures, stormwater runoff quantity and quality, building energy performance and other benefits can be achieved with one targeted application. Green roofs make practical use of a neglected, inaccessible, urban landscape that is currently abundant within all municipalities in Canada and North America. These elevated surfaces do not require 
acquisition permits or legal procurement. They are currently available for green roof assessment - particularly public buildings with government ownership. Depending on the environmental risk or municipal concern, green roofs can be aggregated and targeted within specific jurisdictions and thereby benefit neighbourhoods, communities, watersheds, air sheds as well as the constituents and natural biota therein. This researcher would offer that green roof technology is not only a viable urban air pollution mitigation strategy that can be transferred to other municipalities with equal merit but also that green roofs create a safer and more liveable space and as such, a better quality of life for urban dwellers. 


\section{ChAPTER 7: CONCLUSION}

An 'ideal' urban neighbourhood might include a full range of extensive and intensive green roofs that have been planned, installed and aggregated geographically so as to maximize the environmental benefits predicted to arise from green roofs. To mitigate air pollution the green roof would incorporate a deep organic planting medium for deposition on selected and aggregated conventional flat roofs in a targeted neighbourhood. A mixture of small trees, evergreen shrubs (junipers) and native perennial grasses could be established to work synergistically and seasonally to mitigate air contaminants, even in winter months. Species recommended for green roofs are available in German publications; however, more experience and Canadian research are required to develop recommendations for the North American context. Research on green roof plant species to date reflects that irrespective of global location, plants need to be selected for drought and wind tolerance as well as hardiness to extreme temperatures in winter and summer conditions. Climate change is predicted to bring more extreme weather variations and less predictable rainfall in coming years; hence, green roofs plant species will require ongoing study across different climatic regions in Canada.

As demonstrated in the Midtown study, green roofs could be installed in urban aggregations in certain neighbourhoods, or more importantly along sewer sheds or within watershed areas. Green roofs could also be supported within a broad urban environmental policy framework or plan (as is the case in Toronto), where aggregations of green roofs in down town neighbourhoods could collectively work to reduce the volume and pollution load associated with stormwater runoff to local creeks and rivers. As well, green roofs could contribute to a specific overall urban heat island and air pollution mitigation strategy as well as a framework to meet existing Kyoto obligations. Aggregations of green roofs in targeted neighbourhoods could contribute to a collective improvement in perceived quality of life as well as the public health outcomes of long term residents. 
The UFORE model has provided a strong foundation upon which to base the development of green roof policy for municipal, provincial and federal levels governments. As many jurisdictions consider the types of planning mechanisms that support low impact development and reduce urban sprawl, it is ciear that prioritizing the inclusion of natural or green elements is a well-supported idea. Combining green roof technology with expansions in public transportation and green procurements that shift the burden away from burning fossil fuels is predicted significantly benefit air quality among other environmental outcomes. Similarly, further research and investment in renewable energy sources combined with strategies to improve and protect water quality, are part of the overall a necessary strategy for maintaining and creating sustainable communities. Urban planners would do well to heed the results of this report and others that strengthen the role of trees, shrubs and grasses for improving the quality of life in urban areas. As urban space is limited for tree and shrub planting, roofs now offer a reasonable habitat for the placement of vegetation that can benefit the environment and quality of life for people.

If the environmental benefits that accompany the installation of green roofs is so obvious, why then are green roofs not mandated via the building code of Ontario for every new construction both provincially and in the City of Toronto? Unfortunately green roof installation is thwarted by several barriers, not the least of which is the upfront financial costs. Green roof costs approximately twice as much as a conventional roof; therefore, it is difficult for builders and developers to rationalize this perceived economic liability (87). Similarly, there is perception that a green roof will weaken waterproofing despite there being no evidence of such as occurrence to date. Additionally, the following additional barriers tend to slow or delay the implementation of green roofs in North America:

- a dearth of experience with green roof technology among accredited professional groups who design green roof systems 
- inexperience with projecting installation and maintenance costs associated with long term management of green roofs

- lack of industry standards (ASHRAE, ASTM) or guidelines and specifications in the roof sciences

- lack of qualified contractors who can install green roofs and offer warranties

- lack of incentives to make green roof applications more attractive to developers and building owners

Currently a number of green roof demonstration projects and academic research facilities are moving green roof technology forward across North America. While there are many European projects with proven environmental benefits based on specific parameters and plant species - very few publications are available in English. Many green roof researchers throughout North America are striving to make the case that the myriad of urban environmental and social benefits associated with green roofs negate the added 'up front' costs. If this financial hurdle can be gently moved aside, there could be substantive support for green roof installations across in jurisdictions in Canada, particularly Ontario, where smart growth and low impact design strategies are tantamount.

The Midtown study area was comprised by 1,216 ha within the amalgamated City of Toronto. Approximations using $10 \%$ and $20 \%$ of sampled building surfaces were grassed in order to represent green roofs and derive estimates on the effect of green roofs on air pollutant mitigation using the UFORE model. Green roofs significantly reduced air contaminants in the Midtown study area over one year. If the amalgamated City of Toronto with its 63,000 ha of land base supported a green roof policy that could target green roof applications on $5 \%$ of the available building roof surfaces, the environmental benefits, particularly on air quality and human health would be significant. 


\section{REFERENCES}

1. Acks, K., (2003). A Framework for Cost-Benefit Analysis of Green Roofs: Initial Estimates. Personal Comm.

2. Akbari, H., (2002). Heat Island Reduction: an Overview - Effects of Trees and Implementation Issues. Presentation by Lawrence Berkeley Laboratory at the University of Pennsylvannia, LAPR 760, November 13th, 2002.

3. Akbari, H., \& Konopacki, S., (2004). Energy Effects of Heat-Island Reduction Strategies in Toronto, Canada. Energy, 29, 191-210.

4. Akbari, H., Pomerantz, M., \& Taha, H., (2001). Cool Surfaces and Shade Trees to Reduce Energy Use and Improve Air Quality in Urban Areas. Solar Energy, 70, 3, 295-310.

5. Baldocchi, D.D., Hicks, B.B., \& Camara, P., (1987). A canopy stomatal resistance model for gaseous deposition to vegetated surfaces. Atmospheric Environment. 21: 91-101.

6. Bass, B., (2001). Addressing Urban Environmental Problems with Green Roofs. Encyclopaedia of Global Environmental Change. Vol. 3. John Wiley \& Sons, Chichester, UK.

7. Bass, B., Baskaran, B., (2001). Evaluating Rooftop and Vertical Gardens as an Adaptation Strategy for Urban Areas. National Research Council Canada Technical Report NRCC-46737, http//irc.nrc-cnrc.gc.ca/ircpubs.

8. Bass, B., Krayenhoff, S., Martilli, A., Stull, R.B., \& Auld, H., (2002). The Impact of Green Roofs on Toronto's Urban Heat Island. Proceedings from Greening Rooftops for Sustainable Communities, First North American Green Roof Infrastructure Conference, May 29th and 30th, Chicago, 2003.

9. Bass, B., Stull, A., Krayenhoff, S., \& Martilli, R.B., (2002). Modeling the Impact of Green Roof Infrastructure on the Urban Heat Island in Toronto. The Green Roof Infrastructure Monitor, Vol.4, No.1, 2002.

10. British Columbia Institute of Technology (BCIT) (2004). Green Roof Research Facility Grows at Great Northern Way Campus; Update; a Newsletter for the BCIT Community. Vol. 12, Issue 4, October 26th, 2004 and personal communication with Maureen Connelly Green Roof Research Facility Project Manager. 
11. Benvie, S., (2003) Professor, School of Architecture, Ryerson University, Toronto, Ontario. personal communication July 2003.

12. Bidwell, R.G.S., \& Fraser, D.E., (1972). Carbon monoxide uptake and metabolism by leaves. Canadian Journal of Botany. 50: 1435-1439

13. Brenneisen, S., (2003). The Benefits of Biodiversity from Green Roofs Key Design Consequences. Proceedings from Greening Rooftops ior Sustainable Communities, First North American Green Roof Infrastructure Conference, May 29th and 30th, Chicago, 2003.

14. Brenneisen, S., (2004). From Biodiversity Strategies to Agricultural Productivity. Proceedings from Greening Rooftops for Sustainable Communities, 2nd North American Green Roof Infrastructure Conference, June 2-4, Portland, 2004.

15. Colbeck, I. \& Harrison, R.M., (1985). Dry deposition of ozone: some measurements of deposition velocity and of vertical profiles to 100 metres. Atmospheric Environment. 19(11): 1807-1818.

16. Cheney, C., \& Rosenzweig, C., (2003). Green Roofs and Environmental Restoration: Towards an Ecological Infrastructure for New York City; Earth Pledge Foundation/NASA Goddard Institute for Space Studies; Proceedings from Greening Rooftops for Sustainable Communities, First North American Green Roof Infrastructure Conference, May 29th and 30th, Chicago, 2003.

17. Chiotti, Q., Morton, I., Ogilvie, K., Maarouf, A. \& Hellecher, M., (2002). Toward an Adaptation Action Plan. Climate Change and Health in the Toronto-Niagara Region - Summary for Policy Makers. Prepared for the Science, Impacts and Adaptation Issues Table, Government of Canada, and the Toronto-Niagara Region Study on Atmospheric Change.

18. Chiotti,Q., \& Urquizo, N., (1999). The relative magnitude of the impacts and effects of GHG - related emission reductions. Report prepared by Pollution Probe, for Environment Canada ISBN: 0-662-28845-9. Catalogue N'o: En 56-150/2000E.

19. Council Environmental Services, St. Paul, Minnesota, (2003). accessed on April 2nd, 2003, from: http://www.metrocouncil.org/environment/Watershed/bmp/CH3_RPPImp GreenRoof.pdf

20. Course Notes, (2003). Dr. James Li, ES8904, Water Pollution Control Processes; Ryerson University, Toronto, Ontario. July 2003. 
21. Christian, J. E., \& Petrie, T.W., (1996). Sustainable Roofs with Real Energy Savings. Proceedings of the Sustainable Low-Slope Roofing Workshop, ed. Desjariais, A., Oak Ridge National Laboratory, Oak Ridge, Tennessee, p. 99.

22. Davis, K., \& Kim, M., (2003). Vancouver's Green Roof Inventory and Next Steps. Proceedings from Greening Rooftops for Sustainable Communities, First North American Green Roof Infrastructure Conference, May 29th and 30th, Chicago, 2003.

23. Del Barrio, E.P., (1998). Analysis of the green roofs cooling potential in buildings. Energy and Buildings, 27, 179-193.

24. Dyer, A.J., \& Bradley, C.F., (1982). An alternative analysis of flux gradient relationships. Boundary-Layer Meteorology. 22: 3-19

25. English Nature Report: Green roofs: their existing status and potential for conserving biodiversity in urban areas; www.blackredstart.org.uk.

26. Environmental Protection Agency; www.epa.gov/heatisland; retrieved July 2004.

27. Eumorfopoulou, E., \& Aravantinos, D., (1998). The contribution of a planted roof to the thermal protection of buildings in Greece. Energy and Buildings. 27. 29-36.

28. Federal Technology Alert (2004). A New Technology Demonstration Publication, DOE/EE-0298. US Department of Energy, Efficiency and Renewable Energy. www.eere.energy.gov/femp/

29. Frith, M., \& Farell, J., (2003). Green Roofs and the Urban Renaissance in Britain. Proceedings from Greening Rooftops for Sustainable Communities, First North American Green Roof Infrastructure Conference, Chicago, May 2003.

30. Gaffin, S., Rosenzweig, C., Parshall, L.,Beattie, D., Berghage, R., O'Keeffe, G., \& Braman, D., (2005). Energy Balance Modeling Applied to a Comparison of White and Green Roof Cooling Efficiency. Proceedings from Greening Rooftops for Sustainable Cities Conference, Washington, D.C., May 2005.

31. Gedge, D., (2002). Roofspace - A Place for Brownfield Biodiversity? Ecos 22 (3/4) British Association of Nature Conservationists, Gloucester.

32. Gedge, D., (2003). From Rubble to Redstarts...Black Redstart Action Plan Working Group. Proceedings from Greening Rooftops for 
Sustainable Communities, First North Amorican Green Roof Infrastructure Conference, May 29th and 30th, Chicago, 2003.

33. Graham, P., (2003). Evaluating the Stormwater Management Benefits of Green Roofs Through Water Balance Modeling. Proceedings from Greening Rooftops for Sustainable Communities, First North American Green Roof Infrastructure Conference, May 29th and 30th, Chicago, 2003.

34. Greenbaum, A., Wellington, A., \& Pushchak, R., (2003). Environmental Law in Social Context, A Canadian Perspective. Cactus Press. Concord.

35. Greenroofs for Healthy Cities (GHC). "Public Benefits of Green Rooftops: Water," The Cardinal Group. Accessed on March 29th, 2003, from: http://www.greenroofs.ca/grhcc/index.html

36. Greenroof Infrastructure Monitor, volume 4, no.1, 2002 (GRIM) [Electronic version] Greenroofs for Healthy Cities. Accessed on March 29th, 2003, from: http://www.greenroofs.ca/grhcc/index.html

37. Gutteridge, B., (2003). Toronto's Green Roof Demonstration Project. Proceedings from Greening Rooftops for Sustainable Communities, First North American Green Roof Infrastructure Conference, May 29th and 30th, Chicago, 2003.

38. Hart, A., (2003). Monitoring Protocols for Birds, Insects and Plants, City of Chicago Roof Top Garden. Proceedings from Greening Rooftops for Sustainable Communities, First North American Green Roof Infrastructure Conference, May 29th and 30th, Chicago, 2003.

39. Herman, R., (2003). Green Roofs in Germany: Yesterday, Today and Tomorrow. Proceedings from Greening Rcoftops for Sustainable Communities, First North American Green Roof Infrastructure Conference, May 29th and 30th, Chicago, 2003.

40. Hewings, J., (2001). Air quality indices: A review. A report prepared for Environment Canada by Pollution Probe. ISBN: 0-919764-50-9.

41. Hosker, R.P., \& Jr., Lindberg, S.E., (1982). Review: atmospheric deposition and plant assimilation of gases and particles. Atmospheric Environment. 16(5): 889-910.

42. Hutchinson, D. Abrams, P., Retzlaff, R., \& Liptan, T., (2003). Stormwater Monitoring Two Ecoroofs in Portland, Oregon, USA. Proceedings from Greening Rooftops for Sustainable Communities, First North American 
Green Roof Infrastructure Conference, May 29th and 30th, Chicago, 2003.

43. Johnson, J., \& Newton, J., (1996). Building Green, A Guide for Using Plants on Roofs Walls and Pavement, The London Ecology Unit, London.

44. Kenney, W.A., (2001).The Environmental role of Toronto's urban forest. University of Toronto, Department of Forestry, Toronto, Ontario.

45. Killus, J.P., Meyer, J.P., Durran, D.R., Anderson, G.E., Jerskey, T.N., Reynolds, S.D., \& Ames, J., (1984). Continued research in mesoscale air pollution simulation modeling. Volume $\mathrm{V}$ : refinements in numerical analysis, transport, chemistry and pollutant removal. Publ. EPA/600/384/095. Research Triangle Park, NC: US Environmental Protection Agency.

46. Kohler, M., (2003). Plant Survival Research and Biodiversity: Lessons From Europe. Proceedings from Greening Rooftops for Sustainable Communities, First North American Green Roof Infrastructure - Conference, May 29th and 30th, Chicago, 2003.

47. Kohler, M., Schmidt, M., Grimme, F. W., Laar, M., Paiva, V.L., \& Tavares, S., (2002). Green Roofs in Temperate Climates and in the HotHumid Tropics - Far Beyond the Aesthetics. Environmental Management and Health, Vol. 13, No.4, 382-391.

48. Laberge, K.M., (2003). Urban Oasis: Chicago's City Hall Green Roof. Proceedings from Greening Rooftops for Sustainable Communities, First North American Green Roof Infrastructure Conference, May 29th and 30th, Chicago, 2003.

49. Leadership in Energy and Environmental Design; LEED; www.usgbs.org/LEED/LEED_main.asp; accessed August 2003.

50. Liesecke H., (1998). Potential Water Retention in Greenroofs: Water retentioin Capabilities, storing water, delayed run-off, by products in runoff in greenroofs. Das Retensionsvermogen von Dachbegrunungen; Stadt Und Grun. 47: 46-53. German translation to English, (unofficial)

51. Liptan, T., (2003). Planning, Zoning and Financial Incentives for Ecoroofs in Portland, Oregon. Proceeding, from Greening Rooftops for Sustainable Communities, First North American Green Roof Infrastructure Conference, May 29th and 30th, Chicago, 2003. 
52. Lovett, G.M., (1994). Atmospheric deposition of nutrients and pollutants in North America: an ecologica! perspective. Ecological Applications. 4: 629-650.

53. Liu, K. (2003). Engineering Performance of Rooftop Gardens Through Field Evaluation. Proc 18th International Convention of Roof Consultants Institute. P. 93-103.

54. Liu, K., \& Baskaran, B, (2003). Thermal Performance of Green Roofs Through Field Evaluation. Presented at; Greening Rooftops for Sustainable Communities, First North American Green Roof Infrastructure Conference, May 29th and 30th, Chicago.

55. Liu, K.,\& Boivin, M.A., (2002). Plant Survivability and Stormwater Management in Ottawa, in the Green Roof Infrastructure Monitor, Vol. 4, No. 1 and

56. Luvall, J.C., \& Holbo, H.R., (1989). Measurements of short term thermal responses of Coniferous Forest Canopies Using Thermal Scanner Data. Remote Sens. Environ., 27, 1-10.

57. Maclver, D., \& Urquizo, N., (1999). Environment Canada Report; Atmospheric Change in Canada: An Integrated Overview.

58. MacMillan, G., (2004). York University Rooftop Garden Stormwater Quantity and Quality Performance Monitoring Report. Proceedings from the 2nd Greening Rooftops for Sustainable Communities Conference, Portland, Oregon, June, 2004.

59. Marcus, D.D. \& Barnes, M.,(1999). Healing Gardens: Therapeutic Benefits and Design Recommendations. Wiley \& Sons, New York.

60. Marsh, W.M., (1991). Landscape Planning: Environmental Applications. Wiley \& Sons, New York.

61. Martelli, A., Clappier, A., \& Rotach, MW., (2002). An Urban Surface Exchange Parameterization for Mesoscale Models. Boundary-Layer Meteor (in press).

62. Maryland Department of Environmental Resources (MDER), Low-Impact Development Design Strategies: An Integrated Design Approach [Electronic version], USEPA, Prince George's County, Maryland, (1999). Accessed on February 4th, 2003, from: http://www.epa.gov/owow/nps/lidnatl.pdf 
63. Maxwell, E.L., (1994). A meteorological/statistical solar radiation model. In: Proceedings of the 1994 annual conference of the American Solar Energy Society. San Jose, CA: American Solar Energy Society: 421426.

64. McPherson, E.G., Nowak, D.J., \& Rowntree, R.A., (1994). Chicago's Urban Forest Ecosystem: Results of the Chicago Urban Forest Climate Project. Gen. Tech. Rep. NE -186. Radnor, PA: U.S. Department of Agriculture, Forest Service, Northeastern Forest Experiment Station, 5 Radnor Corporate Center, Pennsylvania.

65. McPherson, E.G., Scott, K.I., \& Simpson, J.R., (1998). Estimating cost effectiveness of residential yard trees for improving air quality in Sacramento, California, using existing models. Atmospheric Environment, 32, 1, 75-84.

66. Metropolitan Council/Barr Engineering Co. (MINN), "Minnesota Urban Small Sites BMP Manual: Impervious Surface Reduction: Green Rooftops," [Electronic version], Metropolitan Council Environmental Services, St.Paul, Minnesota, 2003. accessed on May 12th, 2003 from:

http://www.metrocouncil.org/environment/Watershed/bmp/CH3_RPPImp GreenRoof.pdf

67. Minke, G., \& Witter, G., (1982). Haeuser mit Gruenem Pelz, Ein Handbucti zur Hausbegruenung, Verlag Dieter Fricke GmbH, Frankfurt (partially translated in English).

68. Monteith, J.L., \& Unsworth, M.H., (1990). Principles of environmental physics. New York: Edward Arnold, p. 291.

69. Monteith, D.B., (1979). Whole tree weight tables for New York. AFRI Res. Rep. 40. Syracuse, NY: State University of New York, College of Environmental Science and Forestry, Applied Forestry Research Institute. $64 \mathrm{p}$.

70. Moran, A., Hunt, B., Jennings, G., (2003). A North Carolina Field Study to Evaluate Green Roof Runoff Quantity, Runoff Quality and Plant Growth. ASAE (American Society of Agricultural Engineers). No. 032303. St. Joseph, Michigan.

71. Murray, F.J., Marsh, L., \& Bradford, P.A., (1994). New York State Energy Plan, Vol. II: Issue Reports. Albany, NY: New York State Energy Office.

72. Niachou, A., Papakonstantinou, K., Santamouris, M., Tsangrassoulis, A., \& Mihalakakou, G., (2001). Analysis of the green roof thermal properties 
and investigation of its energy performance. Energy and Buildings. 33, 719-729.

73. North American Wetland Engineering, PA; Ecology, Construction and Benefits in ReNature/NAWE Green Roof Product Literature, Minnesota, May 1998.

74. Nowak, D. J., ( 1995). Trees, Pollute? A TREE explains is all. In Kollin, C., Barratt, M., eds, In: Proceedings of the national urban forestry conference. Washington, DC: American Forests: 28-30.

75. Nowak, D.J., Crane, D.E., Stevens, J.C., \& Ibarra, M., (2002). Brooklyn's Urban Forest. USDA Forest Service, Northeastern Research Station, General Technical Report NE-290.

76. Nowak, D.J., Civerolo, K.L., Rao, S.T., Sistla, G., Juley, C.J., \& Crane, D.E., (2000). A modeling study of the impact of urban trees on ozone. Atmospheric Environment, 34, 1601-1613.

77. Nowak, D.J., \& Crane, D.E., (1998). The Urban Forest Effects (UFORE) Model: Quantifying Urban Forest Structure and Functions. Integrated Tools Proceedings. Boise, Idaho, USA, August 16-20th.

78. Nowak, D.J., \& Dwyer, J.F.,(2001) Understanding the Benefits and Costs of Urban Forest Ecosystems. In Handbook of Urban and Community Forestry in the Northeast. J.E., Kluwer, Academic/Plenum Publishers, New York.

79. Nowak, D.J., McHale, P.J., Ibarra, M., Crane, D., Stevens, J.C., and Luley, C., (1998). Modeling the effects of urban vegetation on air pollution. Air Pollution Modeling and Its Application XII. Eds. Sven-Erick Gryning and Nadine Chaumerliac, Plenum Press, New York.

80. Oberlander, C.H., Whitelaw, E., \& Matsuzaki, E., (2002). Introductory Manual for Greening Roofs. For Public Works and Government Services Canada.

81. Oberlander, C.H., (1981). An Oasis in the City. Landscape Architectural Review, vol. 2, No. 2. Toronto.

82. Onmura, S., Matsumoto, M., \& Hokoi, S., (2001). Study on Evaporative Cooling Effect of Roof Lawn Gardens. Energy and Buildings, 33, 653 666.

83. O.itario Medical Association. (2001). Ontario's Air: Years of Stagnation. www.oma.org/phealth.report. accessed July 2004. 
84. Ontario Medical Association. (2000). Illness Costs of Air Pollution. www.oma.org/Environmental Health; accessed July 2004

85. Osmundson, T., (1999). Roof Gardens: History, Design and Construction. W.W. Norton \& Company, New York.

86. Peck, S., \& Kunn, M., (2001). Design Guidelines for Green Roofs. Ontario Association of Architects and Canada Mortgage and Housing Corporation.

87. Peck, S., Callaghan, C., Kuhn, M.E., \& Bass, B., (1999).Greenbacks from Green Roofs: Forging a New Industry in Canada. Research Report prepared for Canada Mortgage and Housing Canada.

88. Peck, S., \& Wieditz, I., (2003). Key Steps to Developing Local Green Roof Infrastructure Roof Markets. Proceedings from Greening Rooftops for Sustainable Communities, First North American Green Roof Infrastructure Conference, May 29th and 30th, Chicago, 2003.

89. Pederson, J.R., Massman, W.J., Mahrt, L., Delany, A., Oncley, S., den Hartog, G., Neumann, H.H. Mickle, R.E., Shaw, R.H., Paw U.K.T., Grantz, D.A., MacPherson, J.I., Desjardins, R., Schuepp, P.H., Pearson R., Jr., \& Arcado, T.E.,(1995). California Ozone Deposition Experiment: Methods, Results, and Opportunities. Atmospheric Environment. 29(21): 3115-3132.

90. Pereira-Bron, K., (2001). Up on the Roof: Rooftop Landscaping Remains an Untapped Market in Canada. Turf \& Recreation, Canada's Turf and Grounds Maintenance Authority. January/February, Vol. 14, No 1.

91. Pollution Probe (2002). The Smog Primer. June 2004. www.pollutionprobe.org/Publicatoins/Air.htm

92. Pollution Probe (2004). Primer on Climate Change and Human Health.

93. Reid, R., (1996). Habitat for the Hardy. In Seasons, Federation of Ontario Naturalists, Autumn, pp. 14-22.

94. Rosenfeld, A.H., Akbari, H., Bretz, S., Fishman, B.L., Kurn, D.M., Sailor, D., \& Taha, H. (1995). Mitigation of Urban Heat Islands: Materials, Utility Programs, Updates. Energy and Buildings, 22, 255-265.

95. Rosenfeld, A.H., Akbari, H., Romm, J.J., \& Pomerantz, M., (1998). Cool Communities: Strategies for Heat Island Mitigation and Smog Reduction. Energy and Buildings 28, 51-62. 
96. Rowe, D.B., Rugh, C.L., VanWoert, N., Monterusso, M.A., \& Russell, D. K., (2003.) Green Roof Slope, Substrate Depth and Vegetation Influence Runoff. Proceedings from. Greening Rooftops for Sustainable Communities, First North American Green Roof Infrastructure Conference, May 29th and 3i, ih, Chicago, 2003.

97. Saiz Alcazar, S., \& Bass, B., (2005). Energy Performance of Green Roofs in a Multi-Storey Residential Building in Madrid. Proceedings from Greening Rooftops for Sustainable Communities, Third North American Green Roof Infrastructure Conference, May 4-6th Washington D.C., 2005.

98. Schade, C., (2000). Wasserruckhaltung und Abflubeiwerte bei dunnschichtigen Estensivebegrunungennd. Stadt Und Grun. 2: 95-100 (partially translated in English)

99. Scholz-Barth, K., (2001). Green Roofs: Stormwater Management from the Top Down. Environmental Design + Construction. www.edcmag.com.

100. Slone, D.K., \& Evans, D.E., (2003). Integrating Green Rocis and Low Impact Design into Municipal Storm Water Regulations. Proceedings from Greening Rooftops for Sustainable Communities, First North American Green Roof Infrastructure Conference, May 29th - 30th, Chicago, 2003.

101. Snodgrass, E., (2004). Plants as Design Elements. Proceedings from Greening Rooftops for Sustainable Communities, 2nd Nirth American Green Roof Infrastructure Conference, June 2-4, Portlar,d, 2004.

102. Smith, F.W., Sampson, D.A., \& Long, J.N., (1991). Comparison of leaf area index estimates from allometrics and measured light interception. Forest Science. 37(6): 1682-1688.

103. Stender, I., (2001). Why Spend Money on Green Roof Infrastructure? Submitted for Master's thesis in Master's in Environmental Studies, York University, Toronto, Ontario.

104. Stifter, R., (1997). Greenery on the Roof, a Futuristic, Ecological Building Method; in Hundertwasser, F., For a More Human Architecture in Harmony with Nature, Hundertwasser Architecture, Benedikt Taschen Verlag $\mathrm{GmbH}$, Cologne, pp.156-158. 
105. Tan, P.W.,\& Sia, A., (2005). A Pilot Study Green Roof Project in Singapore. Proceedings from the third Greening Rooftops for Healthy Cities. Washington D.C., May 2005.

106. Theaker, I., Cole, R., Connery, K., \& Rousseau, D., (1999). Green Building Design \& Construction Guidelines. Sheltair Scientific Ltd, City of Santa Monica.

107. Thompson, W., (1998). Grass-Roofs Movement. Landscape Architecture, The Magazine of the American Society of Landscape Architects, Vol. 88, No. 6, pp 47-51.

108. United States Environmental Protection Agency, (1995). PCRAMMIT users guide. Research Triangle Park, NC: U.S. Environmental Protection Agency. $53 \mathrm{p}$.

109. United States Environmental Protection Agency, (1996). National air quality and emissions trends report. 1995. Research Triangle Park, NC: U.S. Environmental Protection Agency. EPA 454/R-96-005.168 p.

110. Viessman Jr., Warren \& Gary L. Lewis. Introduction to Hydrology, 4th ed. Harper Collins, New York, 1996.

111. Wells, M., (2001). Rarity on the Roof? Finding Partial Solutions to Challenges of Brownfield Site Redevelopment, In Practice, 33, pp 14-15, Institute of Ecology and Environmental Management, Winchester.

112. White, J.W., \& Snodgrass, E., (2003). Extensive Greenroof Plant Selection and Characteristics. Proceedings from Greening Rooftops for Sustainable Communities, First North American Green Roof Infrastructure Conference, May 29th and 30th, Chicago, 2003.

113. Wislon, A., \& Rickel Pellitier, M., (2003). Environmental Building News. The leading newsletter on environmentally responsible design and construction. Vol. 10, No. May.

114. Wong, N.H., Cheong, D.K.W., Yan, H., Soh, J., Ong, C. L., \& Sia, A., (2003). The Effects of Rooftop Garden on Energy Consumption of a Commercial Building in Singapore. Energy and Buildings 35, 353-364.

115. Wong, N.H., Chen, Y., Ong, C.L., \& Sia, A., (2003). Investigating of Thermal Benefits of Rooftop Garden in the Tropical Environment. Building and Environment, 38, 261-270. 
116. Wong, N.H., Tay, S.F., Wong, R., Ong, C.L., \& Sia, A., (2003). Life Cycle Cost Analysis of Rooftop Gardens in Singapore. Building and Environment 38, $499-509$.

117. Wullschleger, S.D., Gunderson, C.A., Hanson, P.J., Wilson, K.B., \& Norby, R.J., (2002). Sensitivity of stomatal and canopy conductance to elevated $\mathrm{CO} 2$ concentration - interacting variables and perspectives of scale. New Phytologist, 153: 485-496

118. Yaffe, B., (2004). Toronto Public Health. Air Pollution Burden of Illness in Toronto: 2004 Summary. Toronto: City of Toronto.

119. Yok, T.P., (2003). Thermal Benefits of Green Roofs in Singapore. Proceedings from Greening Rooftops for Sustainable Communities, First North American Green Roof Infrastructure Conference, May 29th and 30th, Chicago.

120. Yok, T.P., \& Sia, A., (2005). A Pilot Green Roof Research Project in Singapore. Proceedings from Green Roofs for Healthy Sustainable Cities Conference, Washington D.C., May 2005.

121. ZinCo International, (1998). Landscaped Roofs in their Most Attractive Form. March, 1998. www.zinco.de/ausland/englishch/ehome.htm

122. Zinke, P.J., (1967). Forest interception studies in the United States. In: Sopper, W.E.; Lull, H.W., eds. Forest hydrology. Oxford, UK: Pergamon Press: $137-161$ 


\section{Project Summary}

\section{Urban Forest Efifets (UFBifa Model}

\section{Introduction}

The Urban Forest Effects (UFORE) model is designed to use standardized field data from randomly located plots, and local hourly air pollution and meteorological data to quantify urban forest structure and numerous urban forest effects for cities across the world. The model currently quantifies:

- Urban forest structure by land use type (e.g., species composition, tree density, tree health, leaf area, leaf and tree biomass, species diversity, etc.).

- Hourly amount of pollution removed by the urban forest, and its associated percent air quality improvement throughout a year. Pollution removal is calculated for ozone, sulfur dioxide, nitrogen dioxide, carbon monoxide and particulate matter (<10 microns).

- Hourly urban forest volatile organic compound emissions and the relative impact of tree species on net ozone and carbon monoxide formation throughout the year.

- Total carbon stored and net carbon annually sequestered by the urban forest.

- Effects of trees on building energy use and consequent effects on carbon dioxide emissions from power plants.

- Compensatory value of the forest, as well as the value of air pollution removal and carbon storage and sequestration.

- Tree pollen allergenicity index.

- Potential impact of Gypsy moth and Asian longhorned beetle infestation.

- Tree transpiration.

New UFORE components currently in development include: Human Comfort; Ultraviolet Radiation Reduction; Wildlife Habitat, Water Quality and Quantity Effects; and more Insect and Disease Potentials.

UFORE results are soon to be compatible with ArcView for display in Geographic Information Systems (GIS) that can incorpcrate digital cover maps to spatially display model results. Procedures for cover mapping from digital aerial photographs or satellite dats have been developed.

A new UFORE Windows program will also be available for PC use in 2003. A field data collection manual has been developed along with handheld data collection programs for PDAs (e.g., Palm Pilots) to facilitate local data collection. All new model analyses have a permanent plot feature to allow for monitoring and analyzes of long-term ecosystem changes.

Cities that have been analyzed using UFORE are: Atlanta, GA; Baltimore, MD; Boston, MA; Brooklyn, NY; Calgary, Alberta; Hefei, China; Jersey City, NJ; Freehold, NJ; Moorestown, NJ; New York, NY; Ningbo, China; Philadelphia, PA; Syracuse, NY; Toronto, Ontario, and Woodbridge, NJ. Cities currently being analyzed are: Baton Rouge, LA; Houston, TX; Morgantown, WV; Phoenix, AZ; San Juan, PR, and Santiago, Chile. Many of these cities are analyzed in cooperation with local institutions. 
New UFORE management decision programs are also in development:

- UFORE Planting Locator: This GIS program will use digital cover maps and other GIS layers to map the best locations to plant trees to improve air quality and building energy conservation.

- UFORE Species Selector: Based on user inputs of planting location attributes (e.g., city, overhead restrictions) and ranking numerous trees factors (e.g., air pollution removal, low pollen emission, fall color) on scale of 0 (unimportant) to 10 (highly important), this Windows program will rank hundreds of tree species to determine the best tree to plant given the user's preferences.

- UFORE Future Effects: This GIS and Windows program will project future canopy cover and benefits of an urban forest over a 30-year period based on estimated forest growth and mortality. The program will also estimate the number of trees that need to be established annually in order to sustain or increase tree cover.

\section{UFORE References}

Nowak, D.J., K.L. Civerolo, S.T. Rao, G. Sistla, C.J. Luley, and D.E. Crane. 2000. A modeling study of the impact of urban trees on ozone. Atmos. Environ. 34: 1601-1613.

Nowak, D.J., and D.E. Crane. 2000. The Urban Forest Effects (UFORE) Model: quantifying urban forest structure and functions. In: Hansen, M. and T. Burk (Eds.) Integrated Tools for Natural Resources Inventories in the $21^{\text {st }}$ Century. Proc. Of the IUFRO Conference. USDA Forest Service General Technical Report NC-212. North Central Research Station, St. Paul, MN. pp. 714-720.

Nowak, D.J. and D.E. Crane. 2002. Carbon storage and sequestration by urban trees in the United States. Environ. Poll. 116(3): 381-389.

Nowak, D.J., D.E. Crane, J.C. Stevens, and M. Ibarra. 2002. Brooklyn's Urban Forest. USDA Forest Service Gen. Tech. Rep. 290. 107 p.

Nowak, D.J., D.E. Crane, and J.F. Dwyer. 2002. Compensatory value of urban trees in the United States. J. Arboric. 28(4): 194-199.

Nowak, D.J. and J.F. Dwyer. 2002. Urban forest structure and value at the national scale. Proc. of the National Urban Forest Conference. Washington, DC. p. 24-25.

Nowak, D.J. and J.F. Dwyer. 2002. Assessing the value of urban forests in the United States. In: 2001 Society of American Foresters National Conference Proceedings. Denver, CO. p. 237-241.

Nowak, D.J., P.J. McHale, M. Ibarra, D. Crane, J. Stevens, and C. Luley. 1998. Modeling the effects of urban vegetation on air pollution. In: Gryning, S.E. and N. Chaumerliac (eds.) Air Pollution Modeling and Its Application XII. Plenum Press, New York. pp. 399-407.

Nowak, D.J. and P. O'Connor. 2001. Syracuse urban forest master plan: guiding the city's forest resource in the $21^{\text {st }}$ century. USDA Forest Service General Technical Report. $50 \mathrm{p}$.

Nowak, D.J., J. Pasek, R. Sequeira, D.E. Crane, and V. Mastro. 2001. Potential effect of Anoplophora glabripennis (Coleoptera: Cerambycidae) on urban trees in the United States. J. Econon. Entomol. 94(1): 16-22.

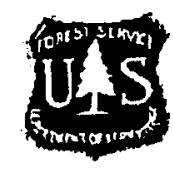

For more information contact:

Dr. David J. Nowak

Project Leader

dnowak@fs.fed.us

USDA Forest Service

(315) 448-3212

Northeastern Research Station

Syracuse, NY 


\section{The Urban Forest Effects (UFORE) Model: Field Data Collection Manual}

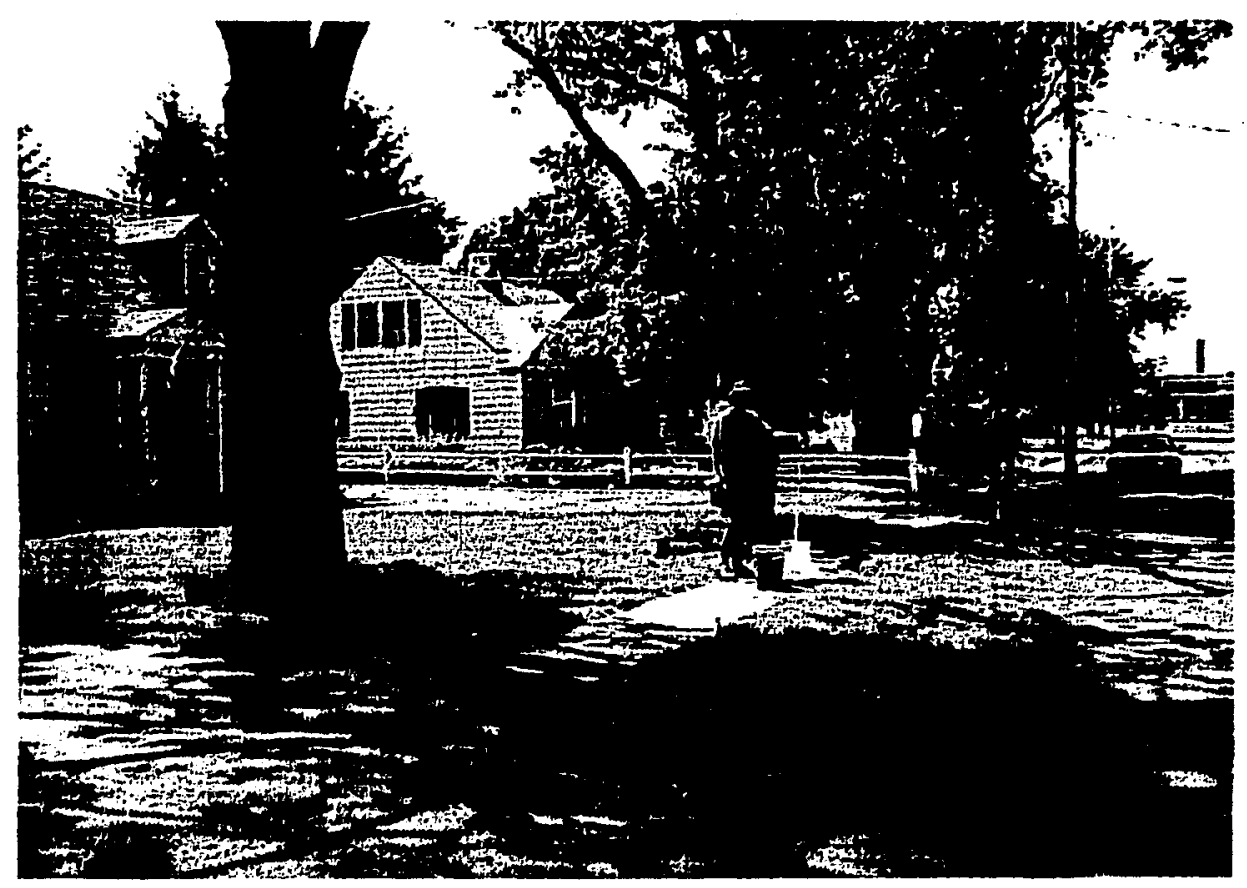

David J. Nowak, Daniel E. Crane, Jack C. Stevens and Robert E. Hoehn USDA Forest Service, Northeastern Research Station 5 Moon Library, SUNY-ESF

Syracuse, NY 13210

(315) 448-3200

July, 2003 
Appendix B. Field Data Sheets
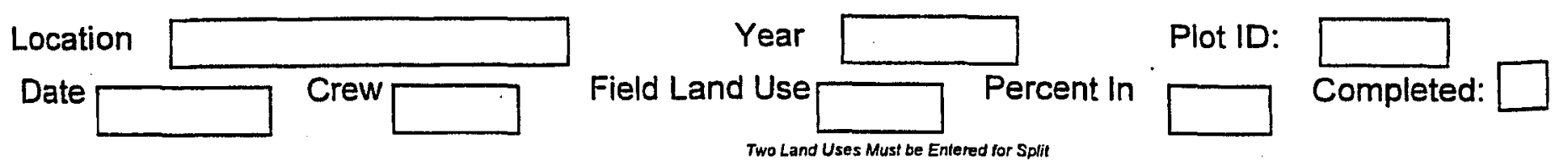

Split Plot $\square$ - - If it is asplit plot then two separate data sheets must be used for following categories.--

\section{Plot / Contact Information}

Address

Phone Number

Resident

Notes:

GPS / Photograph

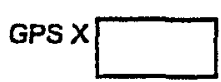

GPSY

GPS Z

Photo \#

\section{......... Reference Objects}

ID Description

Direction

Distance

Notes/Comments (DBH)

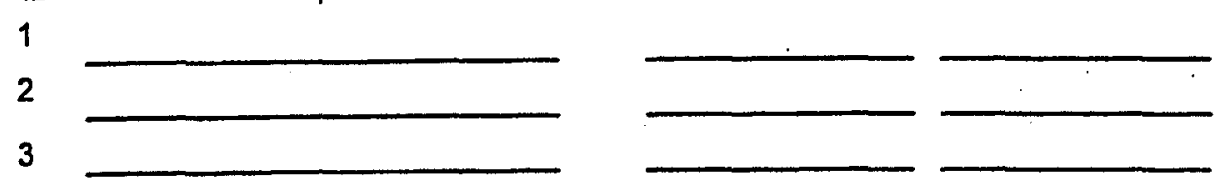

Percent of Plot

Tree Cover

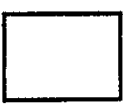

Shrub Cover

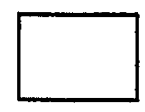

Plantable Space

\section{Ground Covers (Percents)}
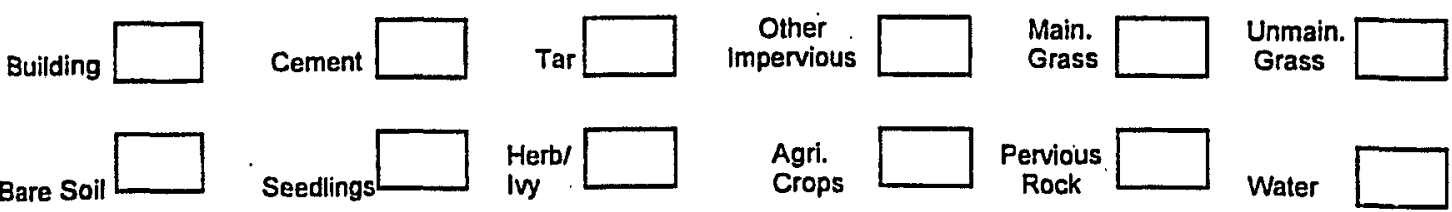

Duff/Mulch
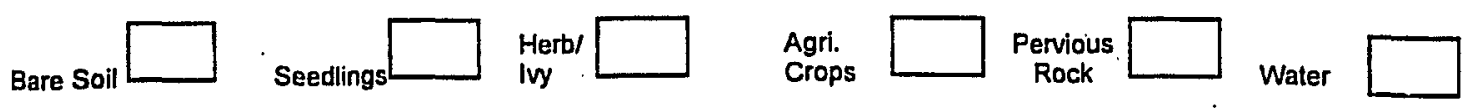

Ground Covers Must Add to $100 \%$

\section{Shrub Data}
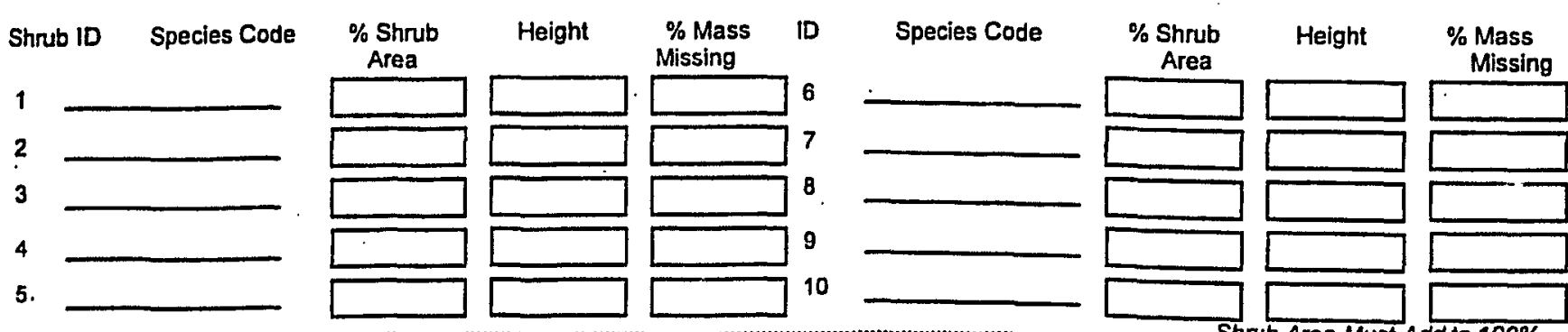

Shrub Area Must Add to 100\% ......................

Notes: 


\begin{tabular}{|c|c|c|c|c|c|c|c|c|c|}
\hline 2 & $\begin{array}{c}\text { Tree } \\
\text { Removal } \\
\text { rate }(\mathrm{g} / \mathrm{m} 2)\end{array}$ & $\begin{array}{c}\text { Shrub } \\
\text { Removal } \\
\text { Rate } \\
\text { (g/m2) }\end{array}$ & $\begin{array}{c}\text { Tree } \\
\text { Pollution } \\
\text { removal(Mg) }\end{array}$ & $\begin{array}{c}\text { Shrub } \\
\text { Pollution } \\
\text { removal(Mg) }\end{array}$ & $\begin{array}{c}\text { Tree } \\
\text { Removal } \\
\text { value (\$) }\end{array}$ & $\begin{array}{c}\text { Shrub } \\
\text { Removal } \\
\text { value (\$) }\end{array}$ & $\begin{array}{c}\text { Grass } \\
\text { Removal } \\
\text { Rate(g/m2) }\end{array}$ & $\begin{array}{c}\text { Grass } \\
\text { Removal } \\
(\mathrm{Mg})\end{array}$ & \begin{tabular}{|c} 
Grass \\
Removal \\
Value (\$)
\end{tabular} \\
\hline \multicolumn{10}{|c|}{ (2) } \\
\hline BASELINE & 0.25576 & 0.25576 & 0.56694 & 0.24584 & 543.69 & 235.77 & & & \\
\hline Green walls & 0.25576 & 0.25576 & 0.063704 & & 61.092 & 0 & & & \\
\hline No big trees & 0.25576 & 0.25576 & 0.21523 & 0.24584 & 206.4 & 235.77 & & & \\
\hline No trees & 0.25576 & 0.25576 & & 0.25096 & & 240.67 & & & \\
\hline Trees low res & 0.25576 & 0.25576 & 0.56694 & 0.24584 & 543.69 & 235.77 & & & \\
\hline Trees off bldg & 0.25576 & 0.25576 & 0.41909 & 0.24584 & 401.91 & 235.77 & & & \\
\hline \multicolumn{10}{|l|}{$\mathrm{NO} 2$} \\
\hline BASELINE & 1.68884 & 1.73994 & 3.74356 & 1.67247 & 25276.5 & 11292.5 & & & \\
\hline Green walls & 2.47137 & & 0.61555 & 0 & 4156.2 & 0 & & & \\
\hline No big trees & 1.45983 & 1.73994 & 1.22846 & 1.67247 & 8294.54 & 11292.5 & & & \\
\hline No trees & & 2.96231 & & 2.90667 & & 19625.8 & & & \\
\hline Trees low res & 1.68884 & 1.73994 & 3.74356 & 1.67247 & 25276.5 & 11292.5 & & & \\
\hline Trees off bldg & 1.66778 & 1.73994 & 2.73279 & 1.67247 & 18451.8 & 11292.5 & & & \\
\hline \multicolumn{10}{|l|}{03} \\
\hline BASELINE & 3.34049 & 3.39535 & 7.40468 & 3.26368 & 49996.4 & 22036.4 & & & \\
\hline Green walls & 4.36181 & &. .08641 & & 7335.41 & & & & \\
\hline No big trees & 3.01846 & 3.39535 & 2.54005 & 3.26368 & 17150.4 & 22036.4 & & & \\
\hline No trees & & 5.09243 & & 4.99677 & & 33738.2 & & & \\
\hline Treẹs low res & 3.34049 & 3.39535 & 7.40468 & 3.26368 & 49996.4 & 22036.4 & & & \\
\hline Trees off bidg & 3.30954 & 3.39535 & 5.42293 & 3.26368 & 36615.6 & 22036.4 & & & \\
\hline \multicolumn{10}{|l|}{ PM10 } \\
\hline BASELINE & 2.51057 & 2.80038 & 5.56504 & 2.69179 & 25087.2 & 12134.6 & & & \\
\hline Green walls & 5.4957 & & 1.36883 & & 6170.67 & & & & \\
\hline No big trees & 2.01429 & 2.80038 & 1.69504 & 2.69179 & 7641.24 & 12134.6 & & & \\
\hline No trees & & 7.3028 & & 7.16563 & & 32302.7 & & & \\
\hline Trees low res & 2.51057 & 2.80038 & 5.56504 & 2.69179 & .25087 .2 & 12134.6 & & & \\
\hline Trees off bldg & 2.47851 & 2.80038 & 4.06123 & 2.69179 & 18308 & 12134.6 & & & \\
\hline \multicolumn{10}{|l|}{$\mathrm{SO} 2$} \\
\hline BASELINE & 0.62017 & 0.65522 & 1.37469 & 0.62981 & 2272.37 & 1041.08 & & & \\
\hline Green walls & 0.91652 & & 0.22828 & 0 & 377.35 & & & & \\
\hline No big trees & 0.57195 & 0.65522 & 0.4813 & 0.62981 & 795.59 & 1041.08 & & & \\
\hline No trees & & 1.06077 & & 1.04085 & 0 & 1720.52 & & & \\
\hline Trees low res & 0.62017 & 0.65522 & 1.37469 & 0.62981 & 2272.37 & 1041.08 & & & \\
\hline Trees off bldg & 0.61834 & 0.65522 & 1.0132 & 0.62981 & 1674.82 & 1041.08 & & & \\
\hline
\end{tabular}

